\title{
The Role of Knowledge Management in Supply Chain Management: A Literature Review
}

\author{
María del Rosario Pérez-Salazar ${ }^{1}$ D , Alberto Alfonso Aguilar Lasserre ${ }^{1}$ D, \\ Miguel Gastón Cedillo-Campos² ${ }^{2}$, José Carlos Hernández González ${ }^{1}$ (DD \\ ${ }^{1}$ Instituto Tecnológico de Orizaba (Mexico) \\ ${ }^{2}$ Mexican Institute of Transportation, National Laboratory for Transportation Systems \& Logistics (Mexico) \\ rosario.perez.salazar@,gmail.com, albertoaal@,hotmail.com,gaston.cedillo@imt.mx,jos car.01@,live.com.mx
}

Received: October 2016

Accepted: September 2017

\section{Abstract:}

Purpose: The aim of this paper is to examine the state of knowledge management research in supply chain management from three standpoints, methodological approach, supply chain management area, and knowledge management processes.

Design/methodology/approach: To achieve this, a systematic review is conducted over the period 2000-2014 on the basis of a qualitative content analysis.

Findings: Major results showed that knowledge management can be viewed as a leverage mechanism for: (i) supply chain integration; (ii) the enhancement of intra and inter-relations across the supply chain; (iii) supply chain strategy alignment; and (iv) the reinforcement of knowledge transfer in product development. Some supply chain management areas such as reverse logistics, inventory management, forecasting/demand planning, outsourcing, and risk management have been explored only to some extent. Furthermore, knowledge transfer is being studied in the majority of the articles, mainly by both case study and survey approach; mathematical models and simulation techniques are used in very limited articles. Findings concerning theoretical perspectives and managerial issues are also described. 
Research limitations/implications: The limitation of our study encompasses the aspects of search period (2000-2014), selection of search databases (Web of Science and SCOPUS and language selection (English).

Practical implications: The exhibition of the KM processes within the SC context may help practitioners and managers interested in implementing $\mathrm{KM}$ initiatives to replicate the methodologies in order to increase the possibilities of a successful $\mathrm{KM}$ adoption.

Originality/value: The systematic review will contribute to the understanding of the present state of research in the knowledge management theory, with focus on the supply chain, as there are no state-of-knowledge studies that report a systematic literature review approach.

Keywords: knowledge management, supply chain, supply chain management, literature review

\section{Introduction}

Derived from the evolution of industries from intensive data processing operation to information-based operations to knowledge-based businesses (Liew, 2008), there is an imperative need to understand knowledge management (KM). This call becomes evident in the context of the supply chain (SC), since a SC can be viewed as an inherently complex and dynamic system of flows, which encompasses material flow and capital flow driven by an information flow and a knowledge flow.

Essentially, the aim of KM is the systematic handling of knowledge and potential knowledge (Heisig, 2009) as Chuang, Liao and Lin (2013) define: " a specific, systemic and organizational process, to create, transfer, integrate and leverage the associated knowledge, that knowledge of a particular functional unit is applied across other functional units that differ in competitive advantage." $\mathrm{KM}$ also involves the development of a set of organizational capabilities which would enable the firm to recognize, create, transform, and distribute knowledge (Gold, Malhotra \& Segars, 2001) with a focus on knowledge flow (Alavi \& Leidner, 2001) and value creation from the intangible resources both within and outside an organization (Rubenstein-Montano, Liebowitz, Buchwalter, McCaw, Newman \& Rebeckl, 2001).

Consequently, KM has to transcend beyond organizational boundaries due to the organization's need to leverage its knowledge resources, therefore, including its partners in the SC (Malhotra, Gosain \& El Sawy, 2005). 
There is theoretical and empirical evidence of $\mathrm{KM}$ been useful in producing encouraging results (Chandra \& Kamrani, 2003; Raisinghani \& Meade, 2005; Chandra \& Tumanyan, 2007; Nachiappan, Gunasekaran \& Jawahar, 2007; Cha, Pingry \& Thatcher, 2008; Chen, Kang, Xing, Lee \& Tong, 2008; Verma \& Tiwari, 2009; Li \& Hu, 2012; More \& Basu, 2013). However, Heisig (2015) highlighted the need to demonstrate the positive influence of $\mathrm{KM}$ as an important challenge to overcome in order for $\mathrm{KM}$ to be accepted as an effective management approach in practice and academia.

For their part, Liew (2008) recognized KM as "one of the major driving forces of organizational change and value creation since the early 1990", which has become more complex as a result of a managerial concept evolution. Consequently, the objective of this study is to examine the state of KM research in supply chain management (SCM) from three standpoints, methodological approach, SCM area, and KM processes.

The rest of the document is structured as follows. Section 2 exposes previous literature reviews and describes the methodology used to perform the systematic review with attention to the development of the review protocol. Section 3 presents the results of the three established standpoints, methodological approach, SCM area, and KM processes. Section 4 discusses key findings, theoretical perspectives and managerial issues In addition, future research directions are also highlighted.

\section{Materials and Methods}

Building from the stages of a systematic review outlined by Tranfield, Denyer and Smart (2003), the methodology consists of three phases: planning, conducting and documenting. The planning phase encompasses the identification for the need of a systematic review and the development of the review protocol. The research protocol provides an explicit description plan to conduct the review with information on the research questions addressed the criteria for inclusion and exclusion of studies in the review, the search strategy, the study selection criteria, the sample that is the focus of the study, the study quality assessment and the data extraction procedures (Tranfield et al., 2003). Sections 2.1 to 2.4 provide a summary of the review protocol.

\subsection{Need for the Systematic Review}

We found previous literature reviews regarding KM in a SC context, which have underlined different scopes. The studies of Chow, Choy and Lee (2005) and Gunasekaran and Ngai (2007) have focused on manufacturing SC. Marra, Ho and Edwards (2012) and Bhosale and Kant (2016) analyze the linkage between KM and SC. The literature review conducted by Chow et al. (2005) (149 papers reviewed from 
1996-2007) resolved that KM practices are successful investments that enable enterprises to develop their SC manufacturing skills for use in build-to-order supply chains. Gunasekaran and Ngai (2007) (number of reviewed papers not specified) reviewed the literature available on KM in manufacturing with the objective of identifying the gap between theory and practice; the paper considered the core functions of manufacturing and incorporating the modern profiles such as SC, enterprise resource planning, virtual enterprise and e-commerce, and developed a framework for KM in advanced manufacturing. For their part, the aim of the study by Marra et al. (2012) (58 papers reviewed from 2000-2010) was to contribute to the debate on the role of KM in SCM by reviewing the published literature; the outcome of the study referred to the statement that KM is considered as a tool for SC integration, however, the evidence of a positive relationship between their use and the success of SC integration is weak. Bhosale and Kant (2016) (176 papers reviewed from 2000-2014) conducted a meta-analysis on the basis of journals involved, number of papers per year, the country in which research carried out, universities under which research carried out, the authors involved, research design, research method, a data analysis technique, industries is an effort to discuss the evolution of $\mathrm{KM}$ in SC domain. We noted that none of the previous cited literature reviews has reported a systematic literature review procedure. Therefore, we can argue a call for this type of study.

\subsection{Research Questions}

The research questions of our study aim to further develop the study of Marra et al. (2012) encompassing the standpoint of SCM area and KM process and also include the research method in order to conduct an overview of the studies. The research questions and their objectives are presented in Table 1.

\begin{tabular}{|c|c|c|}
\hline ID & Question & Objective \\
\hline RQ1 & $\begin{array}{l}\text { Which research methodologies are employed by the } \\
\text { authors? }\end{array}$ & To conduct an overview of the studies. \\
\hline RQ2 & $\begin{array}{l}\text { Which SCM areas are addresses within the KM } \\
\text { perspective? }\end{array}$ & $\begin{array}{l}\text { To identify the SCM areas which are commonly linked } \\
\text { with KM initiatives. Moreover, to analyze how KM has } \\
\text { been applied to the most discussed areas. }\end{array}$ \\
\hline RQ3 & $\begin{array}{l}\text { How the KM processes are associated with the } \\
\text { business process across the SC? }\end{array}$ & $\begin{array}{l}\text { To determine which KM processes are integrated into the } \\
\text { SC business processes. Furthermore, to locate them in the } \\
\text { exploration - exploitation continuum. }\end{array}$ \\
\hline
\end{tabular}

Table 1. Research questions 
From the empirical insights approach, an option for the added value of literature reviews presented by Wee and Banister (2015) in their article entitled How to Write a Literature Review Paper?, published in the Journal Transport Reviews, our study aims to construct a state of knowledge based on the synthesis of the three research questions, namely, a synthesis of what is already known and what is not (Wee \& Banister, 2015).

\subsection{Selection of Studies and Quality Assessment}

The inclusion criteria comprise articles in the context of the SC, where the author examine the KM processes and the context in which they were developed; articles and reviews in peer-reviewed journals, in English language, with published status from January 2000 to December 2014.

The research databases included in this study were: Web of Science and SCOPUS. According to the exclusion criteria, book chapters, unpublished manuscripts, conference proceedings and dissertation/thesis were not included. Although it would be interesting to include the latter type, there was no apparent method for assuring that all relevant theses could be obtained.

The search criterion in the Web of Science database was undertaken using the keywords combination "supply chain" AND "knowledge management" in Topic (title, abstract, keywords), resulting in an initial sample of 396. Next, the search was limited to Document type "article" and "review", thus, 184 studies were found. The same search criterion was applied in SCOPUS. Table 2 summarizes the results of the search strategies carried out.

\begin{tabular}{|l|l|c|}
\hline \multicolumn{1}{|c|}{ Research database } & \multicolumn{1}{c|}{ Search strategy } & \multicolumn{1}{|c|}{ Results } \\
\hline $\begin{array}{l}\text { Web of Science Core } \\
\text { Collection }\end{array}$ & $\begin{array}{l}\text { TOPIC: (“supply chain*”) AND TOPIC: (“knowledge management”) } \\
\text { Timespan: 2000-2014. Indexes: SCI-EXPANDED, SSCI, A\&HCI, CPCI-S, } \\
\text { CPCI-SSH. }\end{array}$ & 396 \\
\hline SCOPUS & $\begin{array}{l}\text { (TITLE-ABS-KEY (“supply chain”) AND TITLE-ABS-KEY (“knowledge } \\
\text { management”)) AND PUBYEAR > 1999 AND PUBYEAR < 2015 }\end{array}$ & 881 \\
\hline $\begin{array}{l}\text { Web of Science Core } \\
\text { Collection }\end{array}$ & $\begin{array}{l}\text { TOPIC: (“supply chain*”) AND TOPIC: (“knowledge management”) } \\
\text { Refined by: DOCUMENT TYPES: (ARTICLE OR REVIEW ) } \\
\text { Timespan: 2000-2014. Indexes: SCI-EXPANDED, SSCI, A\&HCI, CPCI-S, } \\
\text { CPCI-SSH. }\end{array}$ & 184 \\
\hline SCOPUS & $\begin{array}{l}\text { (TITLE-ABS-KEY (“supply chain”) AND TITLE-ABS-KEY (“knowledge } \\
\text { management”)) AND DOCTYPE (ar OR re) AND PUBYEAR > 1999 AND } \\
\text { PUBYEAR < 2015 }\end{array}$ & 343 \\
\hline
\end{tabular}

Table 2. Search criterion results 
Figure 1 illustrates the process of selection and study quality assessment. As a result of the search criterion, 527 publications were retrieved from the databases. Then, the elimination of duplicate papers was carried out removing 65 papers. The 462 resulting references were sorted alphabetically by their authors, which avoided a bias by year of publication or by "relevance".

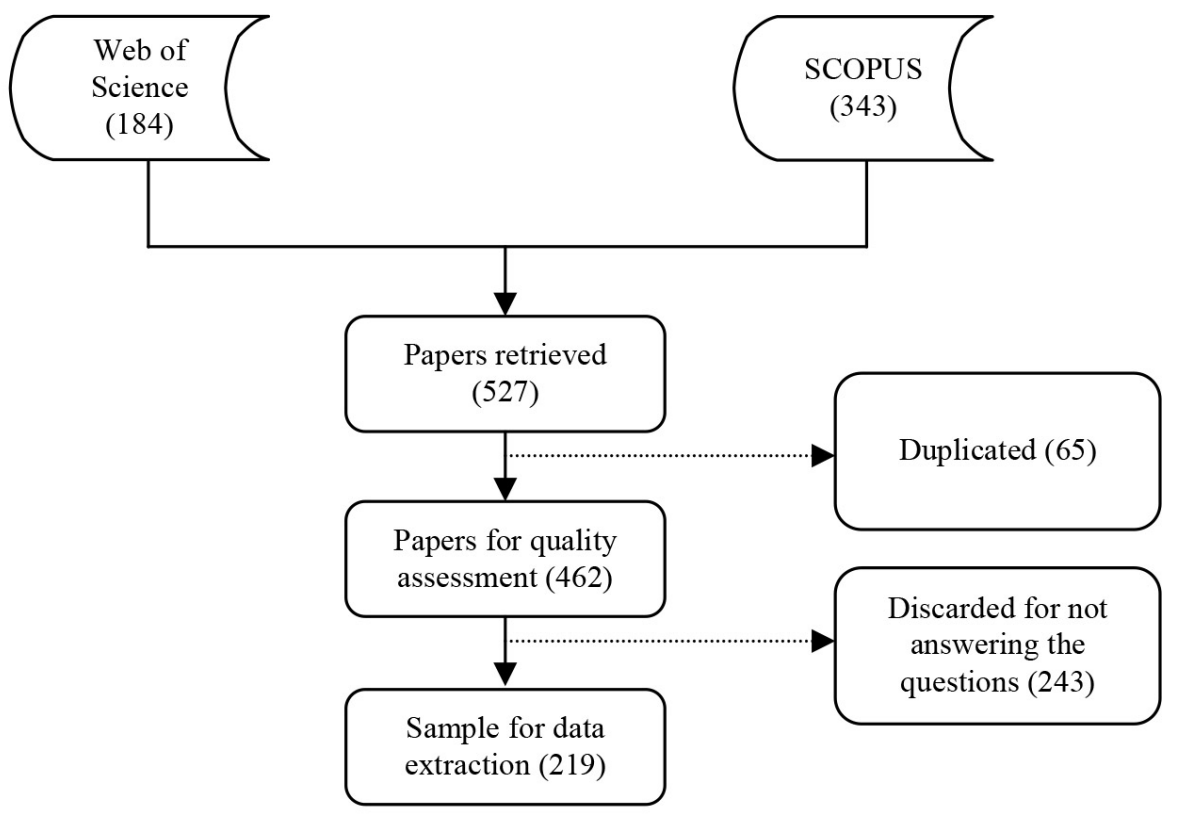

Figure 1. Study selection process

Through work sessions held among the three authors which formed the review team, quality assessment questions were determined to ensure the fit between the research methodology and the research questions (Tranfield et al., 2003). The objectives of the RQ1, RQ2 and RQ3 are attended by the quality assessment questions (Table 3). Therefore, studies were assessed against these quality assessment criteria. Next, we conducted a pilot in which the review team assessed collectively the studies by answering the questions on 30 randomly selected papers from the search in Web of Science Core Collection. At this point, we decided to use the reference management software $\&$ researcher network Mendeley ${ }^{\circledR}$ due to its feature of private groups to collaboratively tag and annotate research papers. 


\begin{tabular}{|l|c|}
\hline \multicolumn{1}{|c|}{ Quality assessment question } & Research question \\
\hline Is the research methodology clearly stated and well-explained? & RQ1 \\
\hline $\begin{array}{l}\text { Is the KM processes identified and sufficiently explained? } \\
\text { Is it clear in which context the KM processes were developed? }\end{array}$ & RQ2 \\
\hline Is the presented SCM area clearly explained? & RQ3 \\
\hline
\end{tabular}

Table 3. Quality assessment questions

The study quality criteria were applied on the title and abstract, and if the study did not answer the questions it was located in the "discarded" category. In addition, the "unsure" category was considered to classify the studies that should be evaluated by the review team through full paper reading until a consensus was reached. After the pilot, agreement was reach among the review team and a detailed interpretation of the study quality criteria was established. The work-load was distributed among the review team. The review team worked independently, two of the authors reviewed all references and the third author reviewed one third. Finally, 219 papers remained for the data extraction.

\subsection{Data Extraction and Analysis}

In accordance with Tranfield et al. (2003), a data-extraction form was employed, a MS Excel@ spreadsheet which contained general study information (title, author, publication details), coding terms related to RQ1, RQ2 and RQ3, and notes on emerging themes attached with details of synthesis. We distributed the data extraction among two authors of the review team, the analysis team. The final sample (219 papers) was randomly assigned to two authors, 110 papers for the first and 109 papers for the second.

The data analysis consisted in a qualitative content analysis perspective following guidelines suggested by Mayring (2015). For each research question, the analysis team accordingly conducted two types of category definition procedures, the deductive procedure and the inductive procedure. The former, develops categories out of theoretical considerations, with theories or theoretical concepts used in a process of operationalization in direction of the material, and the second, develops categories directly out of the material (Mayring, 2015). 


\subsubsection{Research Methodology}

The deductive category scheme definition for the RQ1 was as follows: case study, survey conceptual model, interview, simulation, and mathematical model. A theoretical or empirical case study provides an opportunity to explore a particular subject within the scope of the study. A survey, direct or by internet, comprise selecting an unbiased and representative sample of subjects taken from a group which the researcher wish to study. A conceptual model encompasses theoretical constructs with the aim to understand the subject that the model represents. Simulation is a technique used to construct a model of a phenomenon in order to analyze its behavior. Interviews can be structured or semi-structured questionnaires.

\subsubsection{Supply Chain Management Area}

For the RQ2, the analysis team selected the inductive procedure in order to form the category system. Therefore, the classification scheme emerged during the data extraction process.

\subsubsection{Knowledge Management Processes}

Referring to the RQ3, a deductive category assignment using the "process" knowledge perspective (Alavi \& Leidner, 2001), which refers to the implication for KM as focused on the process of creation, storage, sharing and application of knowledge. Considering the studies proposed by Alavi and Leidner (2001), Gold et al. (2001), Lawson (2003) and Heisig (2009), the following activities comprises each of the four broad KM processes:

i. Knowledge creation: refers to the conscious effort to search and define relevant knowledge and its sources from both within and outside an organization (Lawson, 2003). This process relates to the acquisition organizational capability of obtaining and accumulating knowledge (Gold et al., 2001) as a result of individual cognitive processes and collaborative social interactions (Alavi \& Leidner, 2001).

ii. Knowledge storage: at this stage, storage and retrieval mechanisms are developed to enable an effective and quickly access to knowledge (Lawson, 2003). Therefore, knowledge consistency is imperative as well as the replacement of outdated knowledge (Gold et al., 2001).

iii. Knowledge transfer: it is the process of transferring codified knowledge to meet the specific needs of users for knowledge utilization (Lawson, 2003). This process is driven by the 
existence of both formal and informal transmission channels at various levels (Alavi \& Leidner, 2001).

iv. Knowledge application: denotes the use of knowledge in new situations where users can learn and generate new knowledge (Lawson, 2003). Consequently, at this process the appropriability of knowledge through its application to productive activity is pursued (Grant, 1996).

After selecting the categorization scheme, the data analysis stage is conducted resulting in category frequencies and contingencies interpretation.

\section{Results}

Appendix includes a table, which depicts information for the articles reviewed in this study; it includes the authors, the article title, the publication source and year of publication, the methodological approach employed by the authors, the SCM area, and the KM processes.

\subsection{Methodologies Employed by the Authors}

The research methods identified for this study were: case study, survey conceptual model, interviews, survey and interview, simulation, and mathematical model. The analysis of reviewed papers by research methodology is depicted in Figure 2.

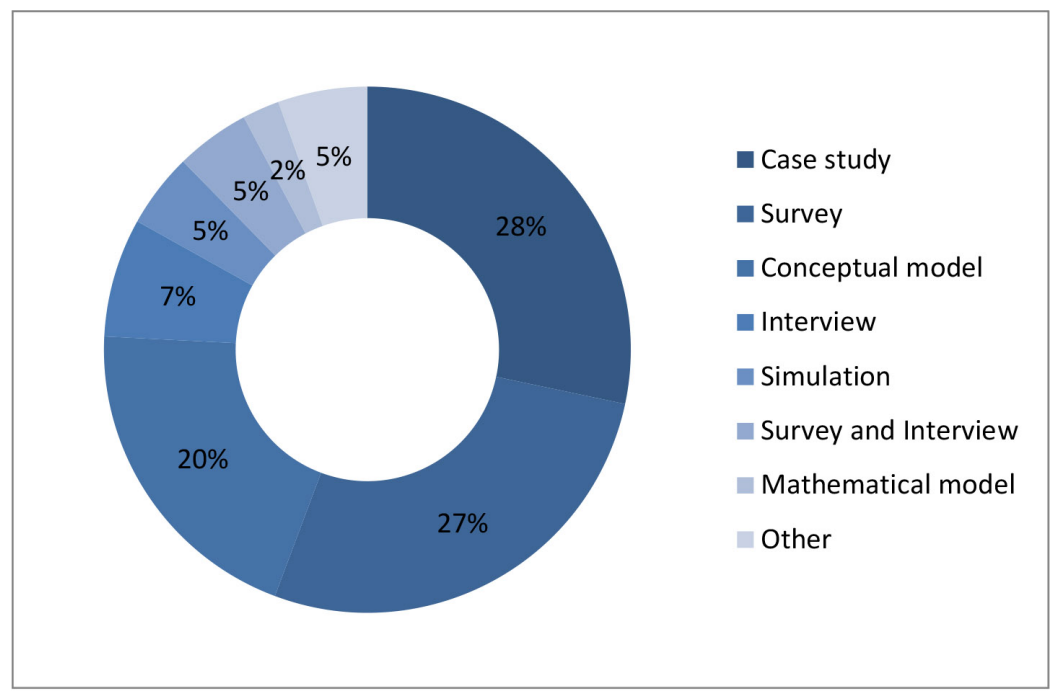

Figure 2. Breakdown of reviewed papers by research methodology 
The case study approach scored highest among all the methodologies used in investigating KM in supply chains. The survey-based analysis stands second regarding the research methods employed in the KM discipline within the SC setting. At the third place, we found conceptual models as a research methodology selected by the authors to contribute to the KM field, rather than mathematical models to prove the theories.

\subsection{Main Supply Chain Management Areas}

The most discussed SCM areas in our reviewed set are: 1) SC integration, 2) intra and inter-firm relations, 3) SC strategy, and 4) product development. The categorization by SCM area is illustrated in Figure 3 specifying the number of studies in each category.

\subsubsection{Supply Chain Integration}

Angeles (2012) evaluated the critical success factors for RFID technology deployment and stated that sharing the costs of the RFID IT infrastructure with business partners in the SC is the most important factor in pursuing market knowledge creation with SC process integration as a moderator. Through a case study in a retail SC, Wamba (2012) identified the RFID technology as an enabler for SC integration. Briscoe, Dainty, and Millett (2001) conducted interviews of construction companies regarding the skills and attitudes appropriate for achieving a better SC integration, their results indicated the skills associated with reading and understanding technical documentation and legal contracts, negotiating and marketing skills, and the motivation and leadership skills, had the highest rates. Concerning hospital SC performance, Chen, Preston and Xia (2013) found that both IT integration and knowledge exchange between the hospital and its suppliers lead to greater hospital-supplier logistical integration. Cheung, Cheung and Kwok (2012) developed a knowledge-based customization system for SC integration with the aim to improve SC visibility by obtaining quantified actionable information and formulating strategies for SC configuration leading the long-term success. Through a case study regarding inter-organizational systems adoption in SMEs, Chong and Bai (2014) showed that knowledge application, knowledge acquisition and knowledge dissemination influenced the decision to adopt technology and improve its SC integration. For their part, Esper, Ellinger, Stank, Flint and Moon (2010) developed a conceptual framework which proposed that the creation of customer value requires demand and supply integration through KM activities, such as prioritizing a shared generation, dissemination, interpretation and application of real-time customer demand as well as ongoing supply capacity constraints. Haug (2013) asserted that the "supply chain product knowledge integration" approach increased the competitiveness of engineer-to-order companies 
and their suppliers. Li, Tarafdar and Rao (2012), through a survey of 411 manufacturing firms, identified the KM processes as the major components of collaborative KM practices. Liu, Ke, Wei and Hua (2013a) was a survey of 246 manufacturing firms. This paper empirically evidenced that information sharing has a positive influence on operational performance; it has no impact on business performance. Based on a knowledge-based view of the SC, Nagati and Rebolledo (2013) empirically examined the effect of both tacit and explicit knowledge transfer from the supplier's position. Within the supply chains of the car industry in Iran, Nikabadi (2014) presented a three layered technology-based framework for KM: information technology tools, information systems integration, and information security management. Shunk, Carter, Hovis and Talwar. (2007) conducted a series of interviews with experts in the electronics industry supply network. The article highlighted that the introduction and acceptance of standards as one of the real drivers to supply network integration. The findings of the survey conducted by Singh and Power (2014) showed the potential to build innovative capability via integration through collaboration for the purpose of accessing, sharing and leveraging knowledge. Xiuhong (2013) proposed a system dynamics model of knowledge transfer as the ability to knowledge integration and expressive power. In the context of manufacturers, Yang, Rui, Rauniar, Ikem and Xie (2013) examined the link between knowledge acquisition and dissemination and SC integration. Yu, Jacobs, Salisbury and Enns (2013) used a survey of 214 manufacturing firms to explore the relationships among internal integration, external integration within their SC and the effect of customer satisfaction on financial performance. Also related to financial performance, Zhang and Huo (2013) considered the influence of both dependence and trust in SC relationships on SC integration.

\subsubsection{Intra and Inter-Firm Relations}

From a resource-based view, Mazzola and Perrone (2013) emphasize that inter-firm relationship makes possible for organizations to possess or acquire resources they are lacking, thus, asserting that competitive advantage depends on possessing a spectrum of unique, rare, durable and inimitable resources. Anbumozhi., Gunjima, Prem Ananth and Visvanathan (2010) proposed a conceptual model for an integrated policy making environment of inter-firm networks. 


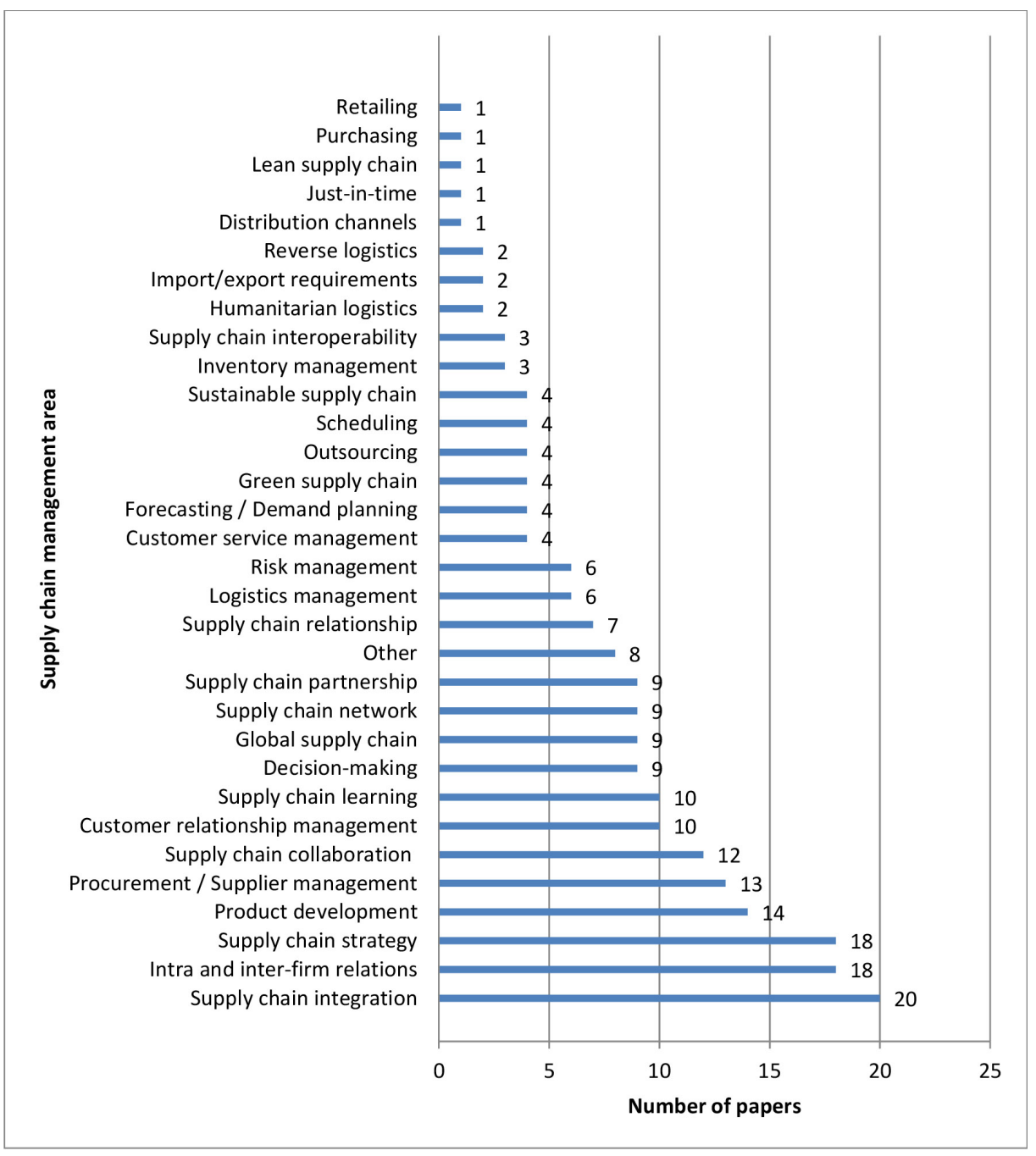

Figure 3. Distribution of the reviewed papers by supply chain management area

Kiessling, Harvey and Moeller (2012) studied the corporate acquisitions in supply chains context. Their paper examined that the development of a psychological contract has a positive impact on the retention of key managers in an acquired organizations. Kim, Umanath, Kim, Ahrens and Kim (2012) conducted structured interviews of 82 firms in the electronics manufacturing services. The findings indicated that overall inter-organizational trust and knowledge complementarity promote knowledge exchange behavior in a supply channel. Li, Liu and Liu (2011) analyzed the knowledge acquisition process in the manufacturing dyadic SC and proposed a conceptual model for the effects of cooperation and conflicts on this KM process. Liu, Huang, Luo and Zhao (2012) applied a survey to a 216 Chinese dyadic manufacturing supply chains. Their research indicates that a higher level of justice mutually perceived by two parties is positively associated with higher levels of linkage behaviors devoted to SC activities by both parties. Maçada, Costa, Oliveira and Curado (2013) took a case study approach within the context of part of an automotive SC in Brazil. Their research model investigated the management of inter-organizational information and share knowledge in an emerging market. The model depicts information management in 
four phases, definition, acquisition, distribution, and usage; includes both explicit and tacit knowledge in three relationship levels: unilateral, bilateral, and multilateral. Machikita and Ueki (2013) surveyed firms in Vietnam and depicted the variance in quality, cost, and delivery caused by knowledge transfer among interconnected firms. The article of Mazzola and Perrone (2013) presents and tests the formation of interfirm relationships, and the choice of governance form. Their approach on inter-firm relationship formation focuses on efficiency need, knowledge need and globalization need. Through a case study in the wood/furniture sector, Mentzas, Apostolou, Kafentzis and Georgolios (2006) aimed to outline the concept of knowledge sharing and trading at the inter-organizational level. Analyzing the dyadic buyersupplier relationship, Paulraj, Lado and Chen (2008) through a survey of 200 United States firms, explained the inter-organizational communication as a strategic relational capability. Zdravković, Panetto, Trajanović and Aubry (2011) developed an ontology framework for the SCOR model with the aim to overcome semantic inconsistencies and incompleteness of the SCOR model, therefore, ensuring that the meaning of the information that is exchanged is automatically interpreted by the receiver of a message. Zhang, Chen, Tong and Liu (2012) through a survey examined the role of market contracts on cross-enterprise knowledge trading in SC highlighting both indirect and direct relational mechanisms. The former, expressed by knowledge brokers, the second consists of shared goals and trust.

\subsubsection{Supply Chain Strategy}

Adewole (2005) performed in-depth interviews in a multiple case approach in small garment manufacturers in the UK. The interviews are used to explore the strategic significance of information to effective SC decisions; findings indicated that an inefficient reaction to an inherently competitive environment is related with unreliable information and knowledge sharing. Arora (2012) linked the use of a simulation-based strategic organizational game and the learning organization perspective. Collins, Worthington, Reyes and Romero (2010) constructed a theoretical overview regarding the relationship between KM, SC technology investments, and overall firm performance. They discussed that firms who endorse capturing data and mining that information, through SC information capturing investments, will be better equipped to identify inherent and imminent changes in the environment and to adjust their strategies accordingly. Based on the resource-based view, knowledge-based view and strategic choice theory, Craighead, Hult and Ketchen (2009) used a survey of 489 firms to empirically assess the link between knowledge development capacity and intellectual capital, innovation-cost strategy, and firm-level performance. They categorized four types of SC strategies based on cost and innovation, "costly imitators", costly innovators", "cost efficient imitators", and "cost efficient innovators"; each SC strategy type requires an assessment on the extent on knowledge development capacity and intellectual capital. Through an exploratory case study at IBM, de Vries and Brijder (2000) proposed a framework for hybrid 
supply channels. Their framework describes that a competitive environment causes channel strategies to take a hybrid form. Therefore, hybrid channel strategies make it necessary to manage and to share knowledge with partners, while IT supports knowledge sharing. Filieri and Alguezaui (2012) described the extended enterprise organizational model, which refers to a set of collaborating companies, including suppliers, vendors, buyers, and customers, both upstream and downstream, that work together to bring value to the marketplace by knowledge-sharing activities to improve innovation performance. Building from a "communicational view" of the SC, the study of Gambetti and Giovanardi (2013) highlights and discusses the supporting role of communication in the enhancement of strategic and operational SC processes. Moreover, they recognized that communication act as a knowledge creation and dissemination activity among the SC stakeholders. Within the context of the strategy of a Danish firm entering the Japanese market, Glisby and Holden (2005) described the key cross-cultural interactions that take place when the firm headquarters representatives are not locally present on a permanent basis, nevertheless, Japanese expatriate employees performs the crucial knowledge transfer activities in order to co-create the market. Gupta (2012) through a case study in the electrical and lighting industry identified the KM areas in terms of continuity and change factors applicable to SCM. The article presents a strategic framework for $\mathrm{KM}$, based on a measurement matrix approach of $\mathrm{KM}$, with perspective of continuity and change in SC providing a specific strategic direction depending upon its score on each KM factor on continuity and change matrix developed. Constructing from a resource-based view, the organizational learning theory, and information-processing literature, Hult, Ketchen and Arrfelt (2007) used a survey of 201 firms to empirically investigate the influence of a culture of competitiveness and knowledge development on SC performance in mixed market turbulence conditions. The major contribution of the article was to inquire on simultaneously consideration of culture of competitiveness and knowledge development, and market turbulence in order to minimize cycle time within a competition environment "supply chain vs. supply chain”. Hult, Ketchen, Cavusgil and Calantone (2006) conducted a profile deviation analysis, using data from 913 manufacturing entities in supply chains, by using ideal "knowledge profiles" for five strategy types, prospectors, analyzers, low-cost defenders, differentiated defenders, and reactors. The author's findings state that capitalizing on knowledge can create superior performance in supply chains, but only if the knowledge elements are aligned with the business strategy. Kant and Singh (2009) took a case study approach to develop a framework to guide KM implementation in supply chains. They introduced the construct of "value proposition" as the strategic knowledge sources identified across the SC. Li and Hu (2012) aimed to outline the significance of SC knowledge sharing using the Prisoner's Dilemma Model of game theory. The authors analyzed and discussed the relationship between knowledge sharing among enterprises and corporate earnings in the SC and concluded that both long-term revenue and operational efficiency could be improved throughout the SC by repeating knowledge sharing between SC members. McLaughlin (2010) took multiple case study approach across six national/multi-national organizations with the aim to identify common traits amongst complex, knowledge-intensive organizations in their approach 
to managing their core business processes in a way that maximizes knowledge transfer. They mentioned that organizations can identified their core business processes as being responsive and flexible, or otherwise, less- responsive. The former could be shown to adopt a common approach to ensure continued performance related knowledge transfer and the second seemed to failure to align their knowledge strategy to their process development. Drawing from the identification of the criteria for SC strategy, business strategy and knowledge management strategy, Nikabadi \& Zamanloo (2012) presented a multidimensional structure to determine the effect of types of strategies on knowledge sharing in the SC of two auto companies in Iran. Results of the study determined that the effective distribution of knowledge in SC is under the effect of hierarchy of strategies. Consequently, SC strategies affect business strategy and business strategy affects $\mathrm{KM}$ strategy, highlighting that it is the KM strategies conduct an effective knowledge sharing in the SC. Samuel, Goury, Gunasekaran and Spalanzani (2011) used a survey of French global companies to empirically present a conceptual framework to study KM in SC networks. Their framework has four phases: socialization, externalization, combination and internalization. The first stage involves a combination of participants' tacit knowledge into a shared mental model takes place; in the second phase, partners begin to exchange explicit information that comes from their own internal tacit knowledge; by the third phase, explicit knowledge has been shared and new models and practices can be developed to create a new knowledge system; and finally, the fourth stage occurs when a company “re-experiences" practices that were learned from other companies' experiences.

\subsubsection{Product Development}

Product development is an area in which firms have to cooperate in order to share knowledge and knowledge management activities have to be developed (Marra et al., 2012). Becker and Zirpoli (2003) took a case study approach at FIAT Auto to analyze the organization of the new product development process within a design outsourcing strategy. The study presents a framework with the focus on integrating dispersed knowledge and the results highlighted that both danger of hollowing out the knowledge base and knowledge integration issues are the two difficulties to implement this strategy. Chandra and Kamrani (2003) through an automotive SC case study analyzed a KM approach for customer- focused product design. They describe a framework of KM through shared ontologies emphasizing the knowledge representation by an ontology-based architecture as a tool for supporting cooperation among agents, thus increasing the quality of SC configuration process. Chen et al.(2008) constructed an analytic hierarchy process (ANP) with sensitivity analysis with the aim to prioritize the relative importance of multiple criteria and the preferences of new product mixes. Their proposed model is used to advise a firm in a network, appropriate $\mathrm{KM}$ and process development management in order to improve the product lifecycle management for the selected new product mix. They constructed a balanced score card to examine the 
outcomes. Within the decision-making process regarding product lifecycle, Chen, Chen and Wu (2010) presented an ontology-based expert recommendation system for product empirical knowledge consultation with the objective to quickly share required product empirical knowledge by interpersonal communication to resolve product-related problems. Chirumalla (2013) used a survey of the aerospace SC to discuss the role of Web 2.0 technologies in managing knowledge across the knowledge life cycle in multicompany product development efforts. They identified that Web 2.0 technologies could be used to leverage informal and unstructured knowledge, contextualized information, networks of connections and to collective create and maintain knowledge assets. Corso and Paolucci (2001) used a survey of 79 manufacturing companies to empirically assess the relations between alternative patterns of IT adoption and knowledge transfer in product innovation. The article tried to explore the role of IT in reinforcing knowledge transfer in product development. They mentioned three approaches to knowledge transfer which represents alternative patterns of IT utilization: firms that only used ICT to automate design activities, firms that utilized ICT to the reuse of knowledge through design solutions and firms where IT is used to support recombination of knowledge for new design solutions. Corso, Martini and Paolucci (2001) proposed a framework with the aim to understand the state of research regarding KM and product innovation. Their findings highlight the need of studies that empirically test the processes through which different forms of knowledge are assimilated, created, transferred, stored and retrieved across dynamic networks, along with the organizational and managerial tools through which firms can influence such processes. Through a survey of 432 new product development projects, Jayaram and Pathak (2013) studied the role of knowledge integration within the context of a collaborative supply chain network. The article presents that both knowledge sharing and enrichment are significant mechanisms for enterprise-wide knowledge integration. Additionally, they discussed that upstream knowledge sharing and enrichment has a significant influence on both product concept effectiveness and manufacturing process performance. Building from the demand chain management standpoint, Liao, Chen and Tseng (2009) applied a survey to 53 insurance companies to investigate the functionality which best fit the consumers' needs and wants for life insurance products. Their research uses the a priori algorithm and clustering analysis as methodologies for data mining with the aim of extracting specific knowledge patterns and rules from consumers. The results are presented as market segments and demand chain analysis on life insurance market for new product development. Liao, Chen and Wu (2008) took a case study approach with an international retailing company to analyze product line and brand extension issues. They developed a relational database and used the a priori algorithm and k-means as methodologies for association rule and cluster analysis for data mining of customer knowledge. Their research offered knowledge patterns/rules and clusters for KM concerning product line and brand extensions. Through a survey of firms' self-reported partners in automotive industries and within the context of product improvement and development, Machikita and Ueki (2012) studied two issues on the role of networked sources of knowledge influential to product innovation, the extend of technology transferred through vertical linkages and public-private alliances 
and the what types of knowledge are transferred from external technology sources. Their results empirically indicated that networked sources of knowledge have a significant influence trade-off between maintaining existing operations and developing new products. McCoy, Thabet and Badinelli (2009) used a survey to present some insights on the role of the developer/builder to further develop the domain-specific commercialization model for residential construction products. They proposed a cross-functional system with the aim of facilitate innovation on a special form of concurrent engineering for construction products called concurrent commercialization. Moreover, their research identified that risk sharing among all members of a product's supply chain is a key determinant to a successful commercialization project. Building from the organizational theory, Tatikonda and Stock (2003) proposed a conceptual model of determinants of product technology transfer success in technology SC. Their proposed model emphasizes the need for fit between the technology uncertainty of the technology to be transferred and the inter-organizational interaction between technology source and recipient firm. Through a case study, Yam, Chan and Chung (2007) presented a business model of knowledge management in networked enterprise for global product design and manufacturing. They argued that KM can be effectively deployed in the management of the collaborative product development process.

\subsection{Knowledge Management Processes}

Building from the construct proposed by Oshri, Pan and Newell (2005) and used in a previous review by Marra et al. (2012) regarding the perception of knowledge exploitation and knowledge exploration activities as two edges of one continuum, we view knowledge creation as a starting point at the exploration-exploitation continuum and knowledge application at the end spectrum. According to the exploration - exploitation continuum (Oshri et al., 2005), the KM processes classification is as follows.

\subsubsection{Exploration}

Knowledge creation is related to customer relationship management (Fahey, Srivastava, Sharon \& Smith, 2001; Nagarajan, Ganesh \& Sundarakani, 2009; Sivakumar \& Roy, 2004; Wu, 2008); customer service management (Chen \& Li, 2006), decision-making (London \& Singh, 2013); global SC (Jean, Sinkovics \& Hiebaum, 2014; Verma \& Tiwari, 2009); humanitarian logistics (Tatham \& Spens, 2011); import/export requirements (Dyer \& Ha-Brookshire, 2008); intra and inter-firm relations (Li et al., 2011; Mazzola \& Perrone, 2013); procurement/supplier management (Giunipero, Handfield \& Eltantawy, 2006; Lintukangas, 2011); product development (Becker \& Zirpoli, 2003; Chen et al., 2008; Liao et al., 2009); risk management (Jüttner \& Maklan, 2011); SC collaboration (Cao, Vonderembse, Zhang \& Ragu-Nathan, 
2010); SC integration (Angeles, 2012; Yu et al., 2013); SC learning (Breite \& Koskinen, 2014); SC network (Lau, Ho, Zhao \& Chung, 2009); SC partnership (Malhotra et al., 2005; Su, Fang \& Young, 2013); SC strategy (Collins et al., 2010); and sustainable SC (Beske, Land \& Seuring, 2014; Van Hoof, 2014). From a morphological approach, Sudhindra, Ganesh and Arshinder (2014) presented a classification of SC knowledge

Knowledge creation and knowledge storage are mentioned by Liao et al. (2008) within product development. For their part, Tah and Carr (2001) mentioned knowledge storage within risk management.

\subsubsection{Exploration and Exploitation}

Create, store and transfer knowledge is discussed by Lee and Chang (2007) within customer relationship management; by Wang, Fergusson, Perry and Antony (2008) within SC learning; by Ye, Yang, Jiang and Tong (2008) within SC interoperability; and Zdravković et al. (2011) within intra and inter-firm relations.

The studies of Chong, Ooi, Bao and Lin (2014) and Tseng (2014) analyzed knowledge creation and knowledge application; the former within decision-making and the second for procurement/supplier management. Additionally, Schoenherr, Griffith and Chandra (2015) stated that tacit knowledge has a greater influence on SC performance than explicit knowledge.

Knowledge creation and knowledge transfer are referred to customer relationship management (Cheng 2010); customer service management (Bjurklo, Edvardsson \& Gebauer, 2009); distribution channels (Reychav, 2009); global SC (Gelderman \& Semeijn, 2006); logistics management (Fugate, Autry, Davis-Sramek \& Germain, 2012; Fugate, Mentzer \& Flint, 2008; Fugate, Stank \& Mentzer, 2009); procurement/supplier management (Al-Karaghouli, Ghoneim, Sharif \& Dwivedi, 2013; Duanmu \& Fai, 2007; Volpato \& Stocchetti, 2007); product development (Corso et al., 2001); retailing (Wrigley, Coe \& Currah, 2005); risk management (Li \& Chandra, 2007); scheduling (Muñoz, Capón-García, Laínez-Aguirre, Espuña \& Puigjaner, 2014); SC integration (Briscoe et al., 2001; Chong \& Bai, 2014; Esper et al., 2010; Halley, Nollet, Beaulieu, Roy \& Bigras, 2010; Haug, 2013; Yang et al., 2013); SC interoperability (Huang \& Lin, 2010); SC learning (Maqsood, Walker \& Finegan, 2007; McLaughlin, Paton \& Macbeth, 2008); supply chain partnership (He, Ghobadian \& Gallear, 2013; Oke, Prajogo \& Jayaram, 2013); SC relationship (Yang, 2012b); and SC strategy (Arora, 2012; Glisby \& Holden, 2005; Gupta, 2012; Samuel et al., 2011; Williams, 2014).

Create, transfer and apply knowledge is referred to customer relationship management (Desouza, Chattaraj \& Kraft, 2003; Fathallah, Stal-Le Cardinal, Ermine \& Bocquet, 2010; Liew, 2008); intra and interfirm relations (Chong et al., 2013); SC learning (Loke, Downe, Sambasivan \& Khalid, 2012; Sambasivan, 
Loke \& Abidin-Mohamed, 2009); SC strategy (Hult et al., 2006); and sustainable SC (Schrettle, Hinz, Scherrer-Rathje \& Friedli, 2014).

The four KM process, knowledge creation, knowledge storage, knowledge transfer and knowledge application are associated with customer service management (Douligeris \& Tilipakis, 2006); decision-making (Li, Kramer, Beulens \& van der Vorst, 2010; Patil \& Kant, 2013, 2014a, 2014b; Raisinghani \& Meade, 2005); forecasting/demand planning (Meixell, Shaw \& Tuggle, 2008); global SC (Liu, Moizer, Megicks, Kasturiratne \& Jayawickrama, 2014; Wang, Wong \& Fan, 2013); intra and inter-firm relations (Im \& Rai, 2008); inventory management (Chan, Cheung, Lee \& Kwok, 2006; Nachiappan et al., 2007); just-in-time (Woolliscroft, Caganova, Cambal, Holecek \& Pucikova, 2013); lean SC (Liu, Leat, Moizer, Megicks \& Kasturiratne, 2013); procurement/supplier management (Akhavan, Elahi \& Jafari, 2014; Choy, Tan \& Chan, 2007); product development (Chandra \& Kamrani 2003; Chen et al., 2010; Chirumalla, 2013; Yam et al., 2007); purchasing (Irani, Sharif, Kamal \& Love, 2014); reverse logistics (Kumar, 2014); scheduling (Muñoz, Capón-García, Laínez, Espuña \& Puigjaner, 2013); SC agility (Liu, Ke, Wei \& Hua, 2013b); SC collaboration (Lin, Hung, Wu \& Lin, 2002; Ulieru, Norrie, Kremer \& Shen, 2000; Wu, 2001; Zacharia, Nix \& Lusch, 2011); SC integration (Cheung et al., 2012; Li et al., 2012; Nikabadi, 2014); SC learning (Daghfous, 2007; Lopez \& Eldridge, 2010); SC network (Prakash, Chan, Liao \& Deshmukh, 2012); SC partnership (Warkentin, Sugumaran \& Sainsbury, 2012; Wong \& Wong, 2011); SC relationship (Yang, Wong, Lai \& Ntoko, 2009); and SC strategy (Hult et al., 2007; Kant \& Singh, 2009). In addition, Patil and Kant (2014) and Patil \& Kant (2014c) determined the barriers and critical success factor for KM adoption within the SC context.

\subsubsection{Exploitation}

Aitken and Harrison (2013) discussed knowledge storage and knowledge transfer within reverse logistics. The studies of Jayaram and Pathak (2013) and Sherwood and Covin (2008) analyzed knowledge transfer and knowledge application; the former within product development and the second for SC partnership.

Knowledge transfer is associated with customer relationship management (Smith, 2009); customer service management (Paton \& McLaughlin, 2008); decision-making (Hedtrich, Loy \& Müller, 2009; Kayakutlu \& Büyüközkan, 2010; Koh \& Tan, 2006); forecasting/demand planning (Pedroso \& Nakano, 2009; Wadhwa, Saxena \& Bibhushan, 2006; Wynn \& Olubanjo, 2012); global SC (Cheung \& Myers, 2008; Cheung, Myers \& Mentzer, 2011; Worasinchai \& Daneshgar, 2012; Zernand-Vilson \& Elenurm 2010); green SC (Cheng, Yeh \& Tu, 2008; Hung, Chen \& Chung, 2014; Kai, Wei \& Meng-Lin, 2014; Qi \& Chen, 2014); humanitarian logistics (Kovács \& Spens, 2010); import/export requirements (Kanat \& Atilgan, 2014); information services (Uusipaavalniemi \& Juga, 2009); intra and inter-firm relations (Anbumozhi et al., 2010; Capó- 
Vicedo et al., 2011; Chen et al., 2014; Cheung et al., 2010; Hernández-Espallardo et al., 2010; Kiessling et al., 2012; Kim et al., 2012; Y. Liu et al., 2012; Maçada et al., 2013; Machikita \& Ueki, 2013; Mentzas et al., 2006; Paulraj et al., 2008; Zhang et al., 2012); inventory management (Zhu, Mukhopadhyay \& Kurata, 2012); logistics management (Norbis, Meixell \& Tuggle, 2013; Rollins, Pekkarinen \& Mehtälä, 2011; Viswanadham \& Gaonkar, 2009); maintenance services (Uusipaavalniemi \& Juga, 2009); outsourcing (Bandyopadhyay \& Pathak 2007; Cha et al., 2008; Choi, Budny \& Wank, 2004; Lu, Meng \& Goh, 2014); procurement/supplier management (Blome, Schoenherr \& Eckstein, 2014; Huang, Stewart \& Chen, 2010; Modi \& Mabert, 2007; Ordoobadi \& Wang, 2011); product development (Corso \& Paolucci, 2001; Machikita \& Ueki, 2012; McCoy et al., 2009; Tatikonda \& Stock, 2003); risk management (Cantor, Blackhurst, Pan \& Crum, 2014; Cerruti \& Delbufalo, 2009; Le, Arch-Int, Nguyen \& Arch-Int, 2013); scheduling (Al-Mutawah, Lee \& Cheung 2009); SC collaboration (Corso, Dogan, Mogre \& Perego, 2010; Eng, 2006; Wadhwa \& Saxena, 2007; Yang, 2012); SC collaboration (Braziotis \& Tannock, 2011; Corso et al., 2010; Eng, 2006; Wadhwa \& Saxena, 2007; Yang, 2012a); SC integration (Chen et al., 2013; Lin, 2014; Liu et al., 2013a; Nagati \& Rebolledo, 2013; Shunk et al., 2007; Singh \& Power, 2014; Wamba, 2012; Xiuhong, 2013; Zhang \& Huo, 2013); SC interoperability (Whitman \& Panetto, 2006); SC learning (Biotto, De Toni \& Nonino, 2012; Tennant \& Fernie, 2013); SC network (Christopher \& Gaudenzi, 2009; Mak \& Ramaprasad, 2003; Purwaningrum \& Evers, 2012; Rao, 2007; Samaddar, Nargundkar \& Daley, 2006; Shih, Hsu, Zhu \& Balasubramanian, 2012); SC partnership (Ke \& Wei, 2007; Malhotra, Gosain \& El Sawy, 2007); relationships in the SC (Cadden, Marshall \& Cao, 2013; Cai, Goh, de Souza \& Li, 2013; More \& Basu, 2013; Thomas, Fugate \& Koukova, 2011; Yazici, 2012); SC strategy (Adewole, 2005; Craighead et al., 2009; de Vries \& Brijder, 2000; Filieri \& Alguezaui, 2012; Gambetti \& Giovanardi, 2013; Li \& Hu, 2012; McLaughlin, 2010; Nikabadi \& Zamanloo, 2012; Thomas, Thomas, Manrodt \& Rutner, 2013); sustainable SC (Cervellon \& Wernerfelt, 2012); and web-enabled SC (Ranganathan, Teo \& Dhaliwal, 2011).

\section{Discussion}

\subsection{Key Findings}

\subsubsection{Methodologies Employed By The Authors}

Among the research methodologies in our consideration set, case study (28 per cent) and survey (27 per cent) represented about one third each one. Simulation and survey and interview, both 5 per cent each and mathematical model represented the smallest share ( 2 per cent), while 5 per cent of all papers were difficult to categorize. 
Sixty two papers contain case studies, of which, thirty six papers provide qualitative findings, whereas, twenty six of the case studies also present quantitative data within their results. Survey based studies are noted by the researchers to collect, analyze and use data to articulate findings with focus on (i) studies that link SC related issues (i.e., SC strategies, business strategies, SC integration, buyer-supplier relationship, cross-functional coordination, product innovation, global manufacturing reach), KM enablers (i.e., knowledge sharing, knowledge development, internal innovation climate, culture of competitiveness, power, IT infrastructure, dependence and trust, e-business applications, networked sources of knowledge, inter-organizational communication) and performance at the SC level or firm level; (ii) SC practices and KM capabilities (i.e., socialization mechanisms and technological innovation capabilities, innovation capabilities, extraction of specific knowledge patterns, supplier relationship management capability, learning capabilities); (iii) KM strategies; and (iv) test and validate conceptual frameworks. Findings also show that conceptual models hold credibility among the qualitative research methods notice by the authors.

\subsubsection{Main Supply Chain Management Areas}

The results from the literature review show a growing number of studies covering different SCM areas. Some of them are: (i) SC integration; (ii) intra and inter-firm relations; (iii) SC strategy; (iv) product development; (v) procurement/supplier management; (vi) SC collaboration; (vii) customer relationship management; and (viii) SC learning. On the other hand, KM has been convincingly applied to some extent in (i) logistics management; (ii) risk management; (iii) customer service management; (iv) forecasting/demand planning; (v) outsourcing; (vi) scheduling; (vii) inventory management; (viii) humanitarian logistics; and (ix) reverse logistics.

\subsubsection{Knowledge Management Process}

There is a clear trend in the reviewed papers towards the middle of this range. More specifically, the knowledge transfer process is discussed in 93 studies. The studies encompassing the four KM processes to some extent represent the second trend. Knowledge creation appeared in third position.

There are technological enablers for the success of KM processes, namely, (i) information and communication technology and (ii) applications and tools (Heisig, 2009). Various studies discuss the role of information and communication technology in KM related projects (Adewole, 2005; Al-Karaghouli et al., 2013; Angeles, 2012; Chen et al., 2013; Chirumalla, 2013; Corso et al., 2010; Corso \& Paolucci, 2001; de Vries \& Brijder, 2000; Gambetti \& Giovanardi, 2013; Huang \& Lin, 2010; Maçada et al., 2013; Nikabadi, 2014; Pedroso \& Nakano, 2009; Rao, 2007; Shih et al., 2012; Uusipaavalniemi \& Juga, 2009; Wynn \& 
Olubanjo, 2012; Zhu et al., 2012). Nevertheless, as Nissen (1999) argues: "a fundamental problem with knowledge management is the information technology employed to enable knowledge work appears to target data and information, as opposed to knowledge itself. In contrast, knowledge-based systems maintain an explicit and direct focus on knowledge."

Along with the acknowledgement of the technological dimension in implementing KM initiatives within the SC context, the KM processes dimension can be understood as a KM capacity. This implies that, at both individual and organizational levels, knowledge absorption depends upon the recipient's capacity to add new knowledge to existing knowledge (Grant, 1996).

\subsection{Theoretical Perspectives}

The knowledge-based view have been used as a theoretical fundamental to discuss the link between KM and SC performance (Hult, Ketchen \& Slater 2004; Craighead et al., 2009; Cheung et al., 2012; Liu et al. 2013a; Singh \& Power, 2014; Blome et al., 2014). The main assumption of the knowledge-based view theory is the understanding of knowledge as a primary productive resource with a strategic connotation in the value adding process (Grant, 1996). Thus, from a knowledge-based view perspective, as argue by Sangari, Hosnavi and Zahedi (2015): "knowledge can be viewed as a source of competitive advantages in supply chain and improved supply chain outcomes."

The resource-based theory also has been noticed by the researchers to approach the KM discipline. From this theoretical perspective, as Halley et al. (2010) argue: "the resource-based view and knowledge management fit together through the translation of resources into knowledge, namely, the efficient use of resources as the notion of organizational learning and the efficient accumulation of resources to face future needs as the task corresponding to KM." The studies of Becker and Zirpoli (2003), Hult et al. (2007), Hult et al. (2006), Halley et al. (2010), Kiessling et al. (2012) and Lin (2014) can be mentioned in this approach.

\subsection{Managerial Issues}

Studies that captured knowledge at firm level have an important implication in this direction. For instance, Wong and Wong (2011) empirically found that the interaction of KM capabilities with the implementation of SCM practices has an influence on firm performance. More specifically, the technological and process KM capabilities along with an effective SCM had a direct and indirect effect on firm performance, therefore, affecting also the SCM practices. In this sense, an imperative call for the alignment of firm's internal KM capability with focus on building stable and long-term relationships with SC partners (Wong 
\& Wong, 2011) will be a promising initiative to respond to the proposition stated by (Hult et al., 2006): "the lack of attention to the link between knowledge (as an intangible resource) and supply chain outcomes is unfortunate because firm and chain outcomes are increasingly intertwined."

Singh and Power (2014) presented some important implications for managers when attempting to resolve the difficult issues associated with configuring inter-firm relationships; the evidence that the integration of knowledge through collaborative practices with both customers and suppliers provides substantial opportunities for firms to improve performance, is one on these. Li, Liu and Liu (2011) discussed the dyadic manufacturer-distributor relationship in China, indicating that there is a call for managers to recognize both, cooperative and competitive capabilities in the potentially entrepreneur trading partners. Referring to knowledge transfer in the UK clothing manufacture industry, the study of Adewole (2005) confirmed that managers acknowledge that information and knowledge flows across the supply chains will benefited with well-defined information strategies. With regard to product development projects, the results of Jayaram and Pathak (2013) provided a guidance to practicing managers on when to engage and what to engage in these type of projects, with respect to supply side and customer side knowledge integration.

\subsection{Research Directions}

Below are presented some future research directions related to the three standpoints undertaken in this work (i) methodological approach, (ii) supply chain management area and (iii) knowledge management processes.

Firstly, regarding the methodological approach, case studies, surveys and conceptual models are the most common research methods adopted by the authors. As emerged in the studies using a case study approach, only twenty six papers out of sixty two exhibit quantitative data. Future studies should consider mathematical or simulation techniques to support evidence on SC outcomes resulted of the implementation of KM.

Secondly, findings show that KM plays an important role in supporting the implementation of SCM practices. More specifically, KM has been linked to: (i) supply chain integration; (ii) intra and inter-relations enhancement to leverage knowledge (i.e., manufacturer-distributor, buyer-supplier, customer relations); (iii) supply chain strategy alignment; and (iv) the reinforcement of knowledge transfer in product development. However, some SCM areas have been explored only to some extent. Other scholars should pay attention to logistics management, risk management, customer service management, forecasting/demand planning, outsourcing and inventory management. There is also an important 
opportunity to conduct studies concerning the context of reverse logistics, human logistics, global SC, green SC and sustainable SC.

Finally, there is a volume of literature about the knowledge transfer process in the reviewed papers. Although, this strand of literature has important contributions to understand the effects that knowledge sharing has on SC outcomes, it pays less attention to the knowledge creation process and the knowledge storage process. Additionally, future studies should focus on knowledge application and its implications related to the ability to use new relevant acquire knowledge to achieve the objectives of the SC.

\section{Conclusion}

This paper attempts to present a literature review of accepted papers available online in scientific English language journals regarding KM within the SC context. Totally, 219 published papers between January 2000 and December 2014 were selected, reviewed, categorized and analyzed to answer three questions: (i) which research methodologies are employed by the authors, (ii) which SCM areas are addressed within the KM perspective and (iii) which SC practices are associated with the creation, storage, transfer and application of knowledge. Building from the results, future research directions are identified and the theoretical perspectives and managerial issues are also discussed.

Mainly, the literature reviewed showed that KM can be viewed as a leverage mechanism for SC integration, intra and inter-firm relations, SC strategy, product development, procurement/supplier management, SC collaboration, customer relationship management and SC learning.

We classified the KM processes according to an exploration - exploitation continuum, in which knowledge creation is the starting point and knowledge application is at the ending of the continuum. An imperative topic of KM is the characterization of the business outcome resulted of the implementation of these $\mathrm{KM}$ processes. Consequently, benefits of KM have to be demonstrated in key management processes, as well as knowledge workers executing KM processes on a daily basis (Heisig, 2009). This effort must be achieved in order to contribute to the acceptance of $\mathrm{KM}$ by practitioners and managers. This conclusion, in particular, puts in evidence that with the aim to continue achieving a solid contribution to the theory construction in the KM field within the SC context, there is a need for a movement towards using replicable methodologies resulting in reliable and useable data to implement the KM frameworks proposed in the theoretical work. 


\section{References}

Adewole, A. (2005). Developing a strategic framework for efficient and effective optimisation of information in the supply chains of the UK clothing manufacture industry. Supply Chain Management: An International Journal, 10(5), 357-366. https://doi.org/10.1108/13598540510624188

Aitken, J., \& Harrison, A. (2013). Supply governance structures for reverse logistics systems. International Journal of Operations \& Production Management, 33(6), 745-764. https://doi.org/10.1108/IJOPM-10-2011-0362

Akhavan, P., Elahi, B., \& Jafari, M. (2014). A new integrated knowledge model in supplier selection. Education, Business and Society: Contemporary Middle Eastern Issues, 7(4), 333-368. https://doi.org/10.1108/IJOPM10-2011-0362

Al-Karaghouli, W., Ghoneim, A., Sharif, A., \& Dwivedi, Y.K. (2013). The effect of knowledge management in enhancing the procurement Process in the UK healthcare supply chain. Information Systems Management, 30(1), 35-49. https://doi.org/10.1080/10580530.2013.739888

Al-Mutawah, K., Lee, V., \& Cheung, Y. (2009). A new multi-agent system framework for tacit knowledge management in manufacturing supply chains. Journal of Intelligent Manufacturing, 20(5), 593-610. https://doi.org/10.1007/s10845-008-0142-0

Alavi, M., \& Leidner, D.E. (2001). Review: Knowledge Management and Knowledge Management Systems: Conceptual Foundations and Research Issues. MIS Quarterly, 25(1), 107-136. https://doi.org/10.2307/3250961

Anbumozhi, V., Gunjima, T., Prem Ananth, A., \& Visvanathan, C. (2010). An assessment of inter-firm networks in a wood biomass industrial cluster: Lessons for integrated policymaking. Clean Tecbnologies and Environmental Policy, 12(4), 365-372. https://doi.org/10.1007/s10098-009-0246-z

Angeles, R. (2012). RFID critical success factors and system deployment outcomes as mitigated by IT infrastructure integration and supply chain process integration. International Journal of Value Chain Management, 6(3), 240-281. https://doi.org/10.1504/IJVCM.2012.050864

Arora, A.S. (2012). The "organization" as an interdisciplinary learning zone: Using a strategic game to integrate learning about supply chain management and advertising. The Learning Organization, 19(2), 121-133. https://doi.org/10.1108/09696471211201489

Bandyopadhyay, S., \& Pathak, P. (2007). Knowledge sharing and cooperation in outsourcing projects - A game theoretic analysis. Decision Support Systems, 43(2), 349-358. https://doi.org/10.1016/j.dss.2006.10.006 
Becker, M.C., \& Zirpoli, F. (2003). Knowledge hollowing-out and knowledge integration - the FIAT Auto case. International Journal of Operations \& Production Management, 23(9), 1033-1061.

https://doi.org/10.1108/01443570310491765

Beske, P., Land, A., \& Seuring, S. (2014). Sustainable supply chain management practices and dynamic capabilities in the food industry: A critical analysis of the literature. International Journal of Production Economics, 152, 131-143. https://doi.org/10.1016/j.ijpe.2013.12.026

Bhosale, V.A., \& Kant, R. (2016). Metadata Analysis of Knowledge Management in Supply Chain: Investigating the Past and Predicting the Future. Business Process Management Journal, 22(1), 140-172. https://doi.org/10.1108/BPMJ-02-2015-0014

Biotto, M., De Toni, A.L., \& Nonino, F. (2012). Knowledge and cultural diffusion along the supply chain as drivers of product quality improvement: The illycaffè case study. The International Journal of Logistics Management, 23(2), 212-237. https://doi.org/10.1108/09574091211265369

Bjurklo, M., Edvardsson, B., \& Gebauer, H. (2009). The role of competence in initiating the transition from products to service. Managing Service Quality, 19(5), 493-510.

https://doi.org/10.1108/09604520910984346

Blome, C., Schoenherr, T., \& Eckstein, D. (2014). The impact of knowledge transfer and complexity on supply chain flexibility: A knowledge-based view. International Journal of Production Economics, 147, 307316. https://doi.org/10.1016/j.ijpe.2013.02.028

Braziotis, C., \& Tannock, J. (2011). Building the extended enterprise: key collaboration factors. The International Journal of Logistics Management, 22(3), 349-372. https://doi.org/10.1108/09574091111181363

Breite, R., \& Koskinen, K.U. (2014). Supply chain as an autopoietic learning system. Supply Chain Management: An International Journal, 19(1), 10-16. https://doi.org/10.1108/SCM-06-2013-0176

Briscoe, G., Dainty, A.R.J., \& Millett, S. (2001). Construction supply chain partnerships: skills, knowledge and attitudinal requirements. European Journal of Purchasing and Supply Management, 7(4), 243-255. https://doi.org/10.1016/S0969-7012(01)00005-3

Cadden, T., Marshall, D., \& Cao, G. (2013). Opposites attract: organisational culture and supply chain performance. Supply Chain Management: An International Journal, 18(1), 86-103. https://doi.org/10.1108/13598541311293203

Cai, S., Goh, M., de Souza, R., \& Li, G. (2013). Knowledge sharing in collaborative supply chains: twin effects of trust and power. International Journal of Production Research, 51(7), 1-17.

https://doi.org/10.1080/00207543.2012.701780 
Cantor, D.E., Blackhurst, J., Pan, M.Y., \& Crum, M. (2014). Examining the role of stakeholder pressure and knowledge management on supply chain risk and demand responsiveness. International Journal of Logistics Management, 25(1), 202-223. https://doi.org/10.1108/IJLM-10-2012-0111

Cao, M., Vonderembse, M., Zhang, Q., \& Ragu-Nathan, T.S. (2010). Supply chain collaboration: conceptualisation and instrument development. International Journal of Production Research, 48(22), 6613-6635. https://doi.org/10.1080/00207540903349039

Capó-Vicedo, J., Mula, J., \& Capó, J. (2011). A social network-based organizational model for improving knowledge management in supply chains. Supply Chain Management: An International Journal, 16(5), 379-388. https://doi.org/10.1108/13598541111139099

Cerruti, C., \& Delbufalo, E. (2009). International sourcing effectiveness in the fashion industry: The experience of Italian industrial districts. International Journal of Globalisation and Small Business, 3(4), 427-440. https://doi.org/10.1504/IJGSB.2009.032261

Cervellon, M.C., \& Wernerfelt, A.S. (2012). Knowledge sharing among green fashion communities online: Lessons for the sustainable supply chain. Journal of Fashion Marketing and Management, 16(2), 176-192. https://doi.org/10.1108/13612021211222860

Cha, H.S., Pingry, D.E., \& Thatcher, M.E. (2008). Managing the knowledge supply chain: an organizacional learning model of information technology offshore outsourcing, 32(2), 281-306. http://www.jstor.org/stable/25148841

Chan, Y.L., Cheung, C.F., Lee, W.B., \& Kwok, S.K. (2006). Knowledge-based simulation and analysis of supply chain performance. International Journal of Computer Integrated Manufacturing, 19(1), 14-23. https://doi.org/10.1080/09511920500174463

Chandra, C., \& Kamrani, A.K. (2003). Knowledge management for consumer-focused product design. Journal of Intelligent Manufacturing, 14(6), 557-580. https://doi.org/10.1023/A:1027358721819

Chandra, C., \& Tumanyan, A. (2007). Organization and problem ontology for supply chain information support system. Data and Knowledge Engineering, 61(2), 263-280. https://doi.org/10.1016/j.datak.2006.06.005

Chen, D.Q., Preston, D.S., \& Xia, W. (2013). Enhancing hospital supply chain performance: A relational view and empirical test. Journal of Operations Management, 31(6), 391-408.

https://doi.org/10.1016/j.jom.2013.07.012

Chen, H.H., Kang, H.Y., Xing, X., Lee, A. H.I., \& Tong, Y. (2008). Developing new products with knowledge management methods and process development management in a network. Computers in Industry, 59(2-3), 242-253. https://doi.org/10.1016/j.compind.2007.06.020 
Chen, Y.-H., Lin, T.-P., \& Yen, D.C. (2014). How to facilitate inter-organizational knowledge sharing: The impact of trust. Information \& Management, 51(5), 568-578. https://doi.org/10.1016/j.im.2014.03.007

Chen, Y.J., Chen, Y.M., \& Wu, M.S. (2010). Development of an ontology-based expert recommendation system for product empirical knowledge consultation. Concurrent Engineering, 18(3), 233-253. https://doi.org/10.1177/1063293X10373824

Chen, Y., \& Li, L. (2006). Deriving information from CRM for knowledge management-A note on a commercial bank. Systems Research and Behavioral Science, 23(2), 141-146. https://doi.org/10.1002/sres.756

Cheng, H.L. (2010). Seeking knowledge or gaining legitimacy? Role of social networks on new practice adoption by OEM suppliers. Journal of Business Research, 63(8), 824-831.

https://doi.org/10.1016/j.jbusres.2009.09.023

Cheng, J.H., Yeh, C.H., \& Tu, C.W. (2008). Trust and knowledge sharing in green supply chains. Supply Chain Management: An International Journal, 13(4), 283-295. https://doi.org/10.1108/13598540810882170

Cheung, C.F., Cheung, C.M., \& Kwok, S.K. (2012). A Knowledge-based Customization System for Supply Chain Integration. Expert Systems with Applications, 39(4), 3906-3924.

https://doi.org/10.1016/j.eswa.2011.08.096

Cheung, M.S., \& Myers, M.B. (2008). Managing knowledge sharing networks in global supply chains. International Journal of Management and Decision Making, 9(6), 581-599. https://doi.org/10.1504/IJMDM.2008.021216

Cheung, M.S., Myers, M.B., \& Mentzer, J.T. (2010). Does relationship learning lead to relationship value? A cross-national supply chain investigation. Journal of Operations Management, 28(6), 472-487. https://doi.org/10.1016/j.jom.2010.01.003

Cheung, M.S., Myers, M.B., \& Mentzer, J.T. (2011). The value of relational learning in global buyer-supplier exchanges: a dyadic perspective and test of the pie-sharing premise. Strategic Management Journal, 32(10), 1061-1082. https://doi.org/10.1002/smj.926

Chirumalla, K. (2013). Managing Knowledge for Product-Service System Innovation: The Role of Web 2.0 Technologies. Research-Technology Management, 56(2), 45-53. https://doi.org/10.5437/08956308X5602045

Choi, T.Y., Budny, J., \& Wank, N. (2004). Intellectual property management: a knowledge supply chain perspective. Business Horizons, 47(1), 37-44.https://doi.org/10.1016/j.bushor.2003.11.006

Chong, A.Y.L., \& Bai, R. (2014). Predicting open IOS adoption in SMEs: An integrated SEM-neural network approach. Expert Systems with Applications, 41(1), 221-229. https://doi.org/10.1016/j.eswa.2013.07.023 
Chong, A.Y.L., Chan, F.T.S., Goh, M., \& Tiwari, M.K. (2013). Do interorganisational relationships and knowledge-management practices enhance collaborative commerce adoption? International Journal of Production Research, 51(7), 1-13. https://doi.org/10.1080/00207543.2012.701776

Chong, A.Y.L., Ooi, K.B., Bao, H., \& Lin, B. (2014). Can e-business adoption be influenced by knowledge management? An empirical analysis of Malaysian SMEs. Journal of Knowledge Management, 18(1), 121-136. https://doi.org/10.1108/JKM-08-2013-0323

Chow, H.K.H., Choy, K.L., \& Lee, W.B. (2005). Knowledge management approach in build-to-order supply chains. Industrial Management Data Systems, 17(6), 882-919. https://doi.org/10.1108/02635570710758770

Choy, K.L., Tan, K.H., \& Chan, F.T.S. (2007). Design of an intelligent supplier knowledge management system - An integrative approach. Proceedings of the Institution of Mechanical Engineers, Part B: Journal of Engineering Manufacture, 221(2), 195-211. https://doi.org/10.1243/09544054JEM627

Christopher, M., \& Gaudenzi, B. (2009). Exploiting knowledge across networks through reputation management. Industrial Marketing Management, 38(2), 191-197.

https://doi.org/10.1016/j.indmarman.2008.12.014

Chuang, S.H., Liao, C., \& Lin, S. (2013). Determinants of knowledge management with information technology support impact on firm performance. Information Technology and Management, 14(3), 217-230. https://doi.org/10.1007/s10799-013-0153-1

Collins, J.D., Worthington, W.J., Reyes, P.M., \& Romero, M. (2010). Knowledge management, supply chain technologies and firm performance. Management Research Review, 33(10), 947-960. https://doi.org/10.1108/01409171011083969

Corso, M., Dogan, S.F., Mogre, R., \& Perego, A. (2010). The role of knowledge management in supply chains: Evidence from the Italian food industry. International Journal of Networking and Virtual Organisations, 7(2-3), 163-183. https://doi.org/10.1504/IJNVO.2010.031216

Corso, M., Martini, A., \& Paolucci, E. (2001). Knowledge management in product innovation: an interpretative review. Journal of Management Reviews, 3(4), 341-352. https://doi.org/10.1111/1468-2370.00072

Corso, M., \& Paolucci, E. (2001). Fostering innovation and knowledge transfer in product development through information technology. International Journal of Technology Management, 22(1-3), 126-148. https://doi.org/10.1504/IJTM.2001.002958

Craighead, C.W., Hult, G.T.M., \& Ketchen Jr., D.J. (2009). The effects of innovation-cost strategy, knowledge and action in the supply chain on firm performance. Journal of Operations Management, 27(5), 405-421. https://doi.org/10.1016/j.jom.2009.01.002 
Daghfous, A. (2007). Absorptive capacity and innovative enterprise systems: a two-level framework. International Journal of Innovation and Learning, 4(1), 60-73. https://doi.org/10.1504/IJIL.2007.011475

de Vries, E.J., \& Brijder, H.G. (2000). Knowledge management in hybrid supply channels: a case study. International Journal of Technology Management, 20(5-8), 569-587. https://doi.org/10.1504/IJTM.2000.002882

Desouza, K.C., Chattaraj, A., \& Kraft, G. (2003). Supply chain perspectives to knowledge management: research propositions. Journal of Knowledge Management, 7(3), 129-138.

https://doi.org/10.1108/13673270310485695

Douligeris, C., \& Tilipakis, N. (2006). A knowledge management paradigm in the supply chain. EuroMed Journal of Business, 1(1), 66-83. https://doi.org/10.1108/14502190610750108

Duanmu, J.L., \& Fai, F.M. (2007). A processual analysis of knowledge transfer: From foreign MNEs to Chinese suppliers. International Business Review, 16(4), 449-473. https://doi.org/10.1016/j.ibusrev.2007.04.004

Dyer, B., \& Ha-Brookshire, J.E. (2008). Apparel import intermediaries' secrets to success: Redefining success in a hyper-dynamic environment. Journal of Fashion Marketing and Management, 12(1), 51-67. https://doi.org/10.1108/13612020810857943

Eng, T.Y. (2006). An investigation into the mediating role of cross-functional coordination on the linkage between organizational norms and SCM performance. Industrial Marketing Management, 35(6), 762-773. https://doi.org/10.1016/j.indmarman.2005.05.014

Esper, T.L., Ellinger, A.E., Stank, T.P., Flint, D.J., \& Moon, M. (2010). Demand and supply integration: A conceptual framework of value creation through knowledge management. Journal of the Academy of Marketing Science, 38(1), 5-18. https://doi.org/10.1007/s11747-009-0135-3

Fahey, L., Srivastava, R., Sharon, J.S., \& Smith, D.E. (2001). Linking e-business and operating processes: The role of knowledge management. IBM Systems Journal, 40(4), 889-907. https://doi.org/10.1147/sj.404.0889

Fathallah, A., Stal-Le Cardinal, J., Ermine, J.L., \& Bocquet, J.C. (2010). Enterprise modelling: building a product lifecycle management model as a component of the integrated vision of the enterprise. International Journal on Interactive Design and Manufacturing, 4(3), 201-209. https://doi.org/10.1007/s12008-0100098-0

Filieri, R., \& Alguezaui, S. (2012). Extending the enterprise for improved innovation. Journal of Business Strategy, 33(3), 40-47. https://doi.org/10.1108/02756661211224997 
Fugate, B.S., Autry, C.W., Davis-Sramek, B., \& Germain, R.N. (2012). Does knowledge management facilitate logistics-based differentiation? the effect of global manufacturing reach. International Journal of Production Economics, 139(2), 496-509. https://doi.org/10.1016/j.ijpe.2012.05.008

Fugate, B.S., Mentzer, J.T., \& Flint, D.J. (2008). The role of logistics in market orientation. Journal of Business Logistics, 29(2), 1-26. https://doi.org/10.1002/j.2158-1592.2008.tb00085.x

Fugate, B.S., Stank, T.P., \& Mentzer, J.T. (2009). Linking improved knowledge management to operational and organizational performance. Journal of Operations Management, 27(3), 247-264.

https://doi.org/10.1016/j.jom.2008.09.003

Gambetti, R.C., \& Giovanardi, M. (2013). Re-visiting the supply chain: a communication perspective. Corporate Communications: An International Journal, 18(4), 390-416. https://doi.org/10.1108/CCIJ-03-2012-0021

Gelderman, C.J., \& Semeijn, J. (2006). Managing the global supply base through purchasing portfolio management. Journal of Purchasing and Supply Management, 12(4), 209-217. https://doi.org/10.1016/j.pursup.2006.10.002

Giunipero, L., Handfield, R.B., \& Eltantawy, R. (2006). Supply management's evolution: key skill sets for the supply manager of the future. International Journal of Operations \& Production Management, 26(7), 822-844. https://doi.org/10.1108/01443570610672257

Glisby, M., \& Holden, N. (2005). Applying knowledge management concepts to the supply chain: How a danish firm achieved a remarkable breakthrough in Japan. Academy of Management Executive, 19(2), 85-89. https://doi.org/10.5465/AME.2005.16963397

Gold, A.H., Malhotra, A., \& Segars, A.H. (2001). Knowledge management: an organizational capabilities perspective. Journal of Management Information Systems, 18(1), 688-698. https://doi.org/10.1080/07421222.2001.11045669

Grant, R.M. (1996). Toward a knoweldge-based theory of the firm. Strategic Management Journal, 17, 109-122. https://doi.org/10.1002/smj.4250171110

Gunasekaran, A., \& Ngai, E.W.T. (2007). Knowledge management in 21st century manufacturing. International Journal of Production Research, 45(11), 2391-2418. https://doi.org/10.1080/00207540601020429

Gupta, V.K. (2012). Flexible strategic framework for KM factors with the perspective of continuity and change: study of supply chain of MNCs in electrical and lighting industry. International Journal of Value Chain Management, 6(4), 283-302. https://doi.org/10.1504/IJVCM.2012.052435 
Halley, A., Nollet, J., Beaulieu, M., Roy, J., \& Bigras, Y. (2010). The impact of the supply chain on core competencies and knowledge management: directions for future research. International Journal of Technology Management, 49(4), 297. https://doi.org/10.1504/IJTM.2010.030160

Haug, A. (2013). Improving the design phase through interorganisational product knowledge models. International Journal of Production Research, 51(2), 626-639. https://doi.org/10.1080/00207543.2012.663108

He, Q., Ghobadian, A., \& Gallear, D. (2013). Knowledge acquisition in supply chain partnerships: The role of power. International Journal of Production Economics, 141(2), 605-618.

https://doi.org/10.1016/j.ijpe.2012.09.019

Hedtrich, F., Loy, J.P., \& Müller, R.A.E. (2009). Prediction markets: a powerful tool for supply network management? British Food Journal, 111(8), 811-819. https://doi.org/10.1108/00070700910980937

Heisig, P. (2009). Harmonisation of knowledge management - comparing $160 \mathrm{KM}$ frameworks around the globe. Journal of Knowledge Management, 13(4), 4-31. https://doi.org/10.1108/13673270910971798

Heisig, P. (2015). Future Research in Knowledge Management: Results from the Global Knowledge Research Network Study. In E. Bolisani \& M. Handzic (Eds.), Advances in Knowledge Management: Celebrating Twenty Years of Research and Practice (Vol. 1, pp. 151-182). Springer. https://doi.org/10.1007/978-3-319-09501-1_7

Hernández-Espallardo, M., Rodríguez-Orejuela, A., \& Sánchez-Pérez, M. (2010). Inter-organizational governance, learning and performance in supply chains. Supply Chain Management: An International Journal, 15(2), 101-114. https://doi.org/10.1108/13598541011028714

Huang, C.C., \& Lin, S.H. (2010). Sharing knowledge in a supply chain using the semantic web. Expert Systems with Applications, 37(4), 3145-3161. https://doi.org/10.1016/j.eswa.2009.09.067

Huang, T.T.A., Stewart, R.A., \& Chen, L. (2010). Identifying key enablers to improve business performance in Taiwanese electronic manufacturing companies. International Journal of Operations \& Production Management, 30(2), 155-180. https://doi.org/10.1108/01443571011018699

Hult, G.T.M., Ketchen, D.J., \& Arrfelt, M. (2007). Strategic supply chain management: improving performances through a culture of competitiveness and knowledge development. Strategic Management Journal, 28(10), 1035-1052. https://doi.org/10.1002/smj.627

Hult, G.T.M., Ketchen, D.J., Cavusgil, S.T., \& Calantone, R. J. (2006). Knowledge as a strategic resource in supply chains. Journal of Operations Management, 24(5), 458-475. https://doi.org/10.1016/j.jom.2005.11.009 
Hult, G.T.M., Ketchen, D.J., \& Slater, S.F. (2004). Information processing, knowledge development and strategic supply chain performance. Academy of Management Journal, 47(2), 241-253.

https://doi.org/10.2307/20159575

Hung, S.W., Chen, P.C., \& Chung, C.F. (2014). Gaining or losing? The social capital perspective on supply chain members' knowledge sharing of green practices. Technology Analysis \& Strategic Management, 26(2), 189-206. https://doi.org/10.1080/09537325.2013.850475

Im, G., \& Rai, A. (2008). Knowledge sharing ambidexterity in long-term interorganizational relationships. Management Science, 54(7), 1281-1296. https://doi.org/10.1287/mnsc.1080.0902

Irani, Z., Sharif, A., Kamal, M.M., \& Love, P.E.D. (2014). Visualising a knowledge mapping of information systems investment evaluation. Expert Systems with Applications, 41(1), 105-125. https://doi.org/10.1016/j.eswa.2013.07.015

Jayaram, J., \& Pathak, S. (2013). A holistic view of knowledge integration in collaborative supply chains. International Journal of Production Research, 51(7), 1958-1972. https://doi.org/10.1080/00207543.2012.700130

Jean, R.J.B., Sinkovics, R.R., \& Hiebaum, T.P. (2014). The effects of supplier involvement and knowledge protection on product innovation in customer-supplier relationships: A study of global automotive suppliers in China. Journal of Product Innovation Management, 31(1), 98-113. https://doi.org/10.1111/jpim.12082

Jüttner, U., \& Maklan, S. (2011). Supply chain resilience in the global financial crisis: an empirical study. Supply Chain Management: An International Journal, 16(4), 246-259. https://doi.org/10.1108/13598541111139062

Kai, Q., Wei, C., \& Meng-Lin, B. (2014). Green supply chain knowledge sharing mechanism based on principal-agent theory. Journal of Chemical and Pharmacentical Research, 6(6), 1631-1639. http://www.jocpr.com/

Kanat, S., \& Atilgan, T. (2014). Effects of knowledge management on supply chain management in the clothing sector: Turkish case. Fibres and Textiles in Eastern Europe, 103(1), 9-13. https://wwwinfona.pl/

Kant, R., \& Singh, M. D. (2009). Knowledge management implementation in supply chains: a strategic plan. International Journal of Business Information Systems, 4(6), 655. https://doi.org/10.1504/IJBIS.2009.026697

Kayakutlu, G., \& Büyüközkan, G. (2010). Effective supply value chain based on competence success. Supply Chain Management: An International Journal, 15(2), 129-138. https://doi.org/10.1108/13598541011028732

Ke, W., \& Wei, K.K. (2007). Factors affecting trading partners' knowledge sharing: Using the lens of transaction cost economics and socio-political theories. Electronic Commerce Research and Applications, 6(3), 297-308. https://doi.org/10.1016/j.elerap.2006.06.006 
Kiessling, T., Harvey, M., \& Moeller, M. (2012). Supply-chain corporate venturing through acquisition: Key management team retention. Journal of World Business, 47(1), 81-92.

https://doi.org/10.1016/j.jwb.2010.10.023

Kim, K.K., Umanath, N.S., Kim, J.Y., Ahrens, F., \& Kim, B. (2012). Knowledge complementarity and knowledge exchange in supply channel relationships. International Journal of Information Management, 32(1), 35-49. https://doi.org/10.1016/j.ijinfomgt.2011.05.002

Koh, S.C.L., \& Tan, K.H. (2006). Translating knowledge of supply chain uncertainty into business strategy and actions. Journal of Manufacturing Technology Management, 17(4), 472-485. https://doi.org/10.1108/17410380610662898

Kovács, G., \& Spens, K. (2010). Knowledge sharing in relief supply chains. International Journal of Networking and Virtual Organisations, 7(2-3), 222-239. https://doi.org/10.1504/IJNVO.2010.031219

Kumar, S. (2014). A knowledge based reliability engineering approach to manage product safety and recalls. Expert Systems with Applications, 41(11), 5323-5339. https://doi.org/10.1016/j.eswa.2014.03.007

Lau, H.C.W., Ho, G.T.S., Zhao, Y., \& Chung, N.S.H. (2009). Development of a process mining system for supporting knowledge discovery in a supply chain network. International Journal of Production Economics, 122(1), 176-187. https://doi.org/10.1016/j.ijpe.2009.05.014

Lawson, S. (2003). Examining the relationship between organizational culture and knowledge management. Nova Southeastern University.

Le, H.Q., Arch-Int, S., Nguyen, H.X., \& Arch-Int, N. (2013). Association rule hiding in risk management for retail supply chain collaboration. Computers in Industry, 64(7), 776-784.

https://doi.org/10.1016/j.compind.2013.04.011

Lee, M.C., \& Chang, T. (2007). Linking knowledge management and innovation management in e-business. International Journal of Innovation and Learning, 4(2), 145-159.

https://doi.org/10.4018/9781599049335.ch233

Li, X., \& Chandra, C. (2007). A knowledge integration framework for complex network management. Industrial Management \& Data Systems, 107(8), 1089-1109. https://doi.org/10.1108/02635570710822769

Li, X., \& Hu, J. (2012). Business impact analysis based on supply chain's knowledge sharing ability. Procedia Environmental Sciences, 12,1302-1307. https://doi.org/10.1016/j.proenv.2012.01.425

Li, Y., Kramer, M.R., Beulens, A.J.M., \& Van Der Vorst, J.G.A.J. (2010). A framework for early warning and proactive control systems in food supply chain networks. Computers in Industry, 61(9), 852-862. https://doi.org/10.1016/j.compind.2010.07.010 
Li, Y., Liu, Y., \& Liu, H. (2011). Co-opetition, distributor's entrepreneurial orientation and manufacturer's knowledge acquisition: Evidence from China. Journal of Operations Management, 29(1-2), 128-142. https://doi.org/10.1016/j.jom.2010.07.006

Li, Y., Tarafdar, M., \& Rao, S.S. (2012). Collaborative knowledge management practices: Theoretical development and empirical analysis. International Journal of Operations \& Production Management, 32, 398-422. https://doi.org/10.1108/01443571211223077

Liao, S.H., Chen, C.M., \& Wu, C.H. (2008). Mining customer knowledge for product line and brand extension in retailing. Expert Systems with Applications, 34(3), 1763-1776.

https://doi.org/10.1016/j.eswa.2007.01.036

Liao, S.H., Chen, Y.N., \& Tseng, Y.Y. (2009). Mining demand chain knowledge of life insurance market for new product development. Expert Systems with Applications, 36(5), 9422-9437.

https://doi.org/10.1016/j.eswa.2008.12.053

Liew, C.B.A. (2008). Strategic integration of knowledge management and customer relationship management. Journal of Knowledge Management, 12(4),131-146. https://doi.org/10.1108/13673270810884309

Lin, C., Hung, H.C., Wu, J.Y., \& Lin, B. (2002). A knowledge management architecture in collaborative supply chain. Journal of Computer Information Systems, 42(5), 83-94. http://dx.doi.org/10.1080/08874417.2002.11647612

Lin, H.F. (2014). The impact of socialization mechanisms and technological innovation capabilities on partnership quality and supply chain integration. Information Systems and E-Business Management, 12(2), 285-306. https://doi.org/10.1007/s10257-013-0226-z

Lintukangas, K. (2011). Supplier relationship management capability in global supply management. International Journal of Procurement Management, 4(1), 1-19. https://doi.org/10.1504/IJPM.2011.037382

Liu, H., Ke, W., Wei, K.K., \& Hua, Z. (2013a). Effects of supply chain integration and market orientation on firm performance: Evidence from China. International Journal of Operations \& Production Management, 33(3), 322-346. https://doi.org/10.1108/01443571311300809

Liu, H., Ke, W., Wei, K.K., \& Hua, Z. (2013b). The impact of IT capabilities on firm performance: The mediating roles of absorptive capacity and supply chain agility. Decision Support Systems, 54(3), 1452-1462. https://doi.org/10.1016/j.dss.2012.12.016

Liu, S., Leat, M., Moizer, J., Megicks, P., \& Kasturiratne, D. (2013). A decision-focused knowledge management framework to support collaborative decision making for lean supply chain management. International Journal of Production Research, 51(7), 1-15. https://doi.org/10.1080/00207543.2012.709646 
Liu, S., Moizer, J., Megicks, P., Kasturiratne, D., \& Jayawickrama, U. (2014). A knowledge chain management framework to support integrated decisions in global supply chains. Production Planning \& Control, 25(8), 639-649. https://doi.org/10.1080/09537287.2013.798084

Liu, Y., Huang, Y., Luo, Y., \& Zhao, Y. (2012). How does justice matter in achieving buyer-supplier relationship performance? Journal of Operations Management, 30(5), 355-367. https://doi.org/10.1016/j.jom.2012.03.003

Loke, S.P., Downe, A. G., Sambasivan, M., \& Khalid, K. (2012). A structural approach to integrating total quality management and knowledge management with supply chain learning. Journal of Business Economics and Management, 13(4), 776-800. https://doi.org/10.3846/16111699.2011.620170

London, K., \& Singh, V. (2013). Integrated construction supply chain design and delivery solutions. Architectural Engineering and Design Management, 9(3), 135-137. https://doi.org/10.1080/17452007.2012.684451

Lopez, G., \& Eldridge, S. (2010). A working prototype to promote the creation and control of knowledge in supply chains. International Journal of Networking and Virtual Organisations, 7(2-3), 150-162. https://doi.org/10.1504/IJNVO.2010.031215

Lu, Q., Meng, F., \& Goh, M. (2014). Choice of supply chain governance: Self-managing or outsourcing? International Journal of Production Economics, 154, 32-38. https://doi.org/10.1016/j.ijpe.2014.03.022

Maçada, A.C.G., Costa, J.C., Oliveira, M., \& Curado, C. (2013). Information management and knowledge sharing in supply chains operating in Brazil. International Journal of Automotive Technology and Management, 13(1), 18-35. https://doi.org/10.1504/IJATM.2013.052777

Machikita, T., \& Ueki, Y. (2012). Impacts of incoming knowledge on product innovation: technology transfer in auto-related industries in developing economies. Asian Journal of Technology Innovation, 20(sup1), 9-27. https://doi.org/10.1080/19761597.2012.683948

Machikita, T., \& Ueki, Y. (2013). Knowledge transfer channels to Vietnam for process improvement. Management Decision, 51(5), 954-972. https://doi.org/10.1108/MD-08-2012-0600

Mak, K.T., \& Ramaprasad, A. (2003). Knowledge supply network. Journal of the Operational Research Society, 54(2), 175-183. https://doi.org/10.1057/palgrave.jors.2601526

Malhotra, A., Gosain, S., \& El Sawy, O.A. (2005). Absorptive capacity configurations in supply chains: gearing for partner-enabled market knowledge creation. MIS Quarterly, 29(1), 145-187. http://www.jstor.org/stable/25148671 
Malhotra, A., Gosain, S., \& El Sawy, O.A. (2007). Leveraging standard electronic business interfaces to enable adaptive supply chain partnerships. Information Systems Research, 18(3), 260-279. https://doi.org/10.1287/isre.1070.0132

Maqsood, T., Walker, D., \& Finegan, A. (2007). Extending the "knowledge advantage": creating learning chains. The Learning Organization, 14(2), 123-141. https://doi.org/10.1108/09696470710726998

Marra, M., Ho, W., \& Edwards, J.S. (2012). Supply chain knowledge management: A literature review. Expert Systems with Applications, 39(5), 6103-6110. https://doi.org/10.1108/13598540510612721

Mayring, P. (2015). Qualitative Content Analysis: Theoretical Background and Procedures. In A. BiknerAhsbahs, C. Knipping, \& N. Presmeg (Eds.), Approaches to Qualitative Research in Mathematics Education: Examples of Methodology and Methods (pp. 365-380). Springer. https://doi.org/10.1007/978-94-017-9181-6_13

Mazzola, E., \& Perrone, G. (2013). A strategic needs perspective on operations outsourcing and other inter-firm relationships. International Journal of Production Economics, 144(1), 256-267. https://doi.org/10.1016/j.ijpe.2013.02.012

McCoy, A.P., Thabet, W., \& Badinelli, R. (2009). Understanding the role of developer/builders in the concurrent commercialization of product innovation. European Journal of Innovation Management, 12(1), 102-128. https://doi.org/10.1108/14601060910928193

McLaughlin, S. (2010). Six tenets for developing an effective knowledge transfer strategy. Vine, 40(2), 153182. https://doi.org/10.1108/03055721011050668

McLaughlin, S., Paton, R.A., \& Macbeth, D.K. (2008). Barrier impact on organizational learning within complex organizations. Journal of Knowledge Management, 12(2), 107-123. https://doi.org/10.1108/13673270810859550

Meixell, M.J., Shaw, N.C., \& Tuggle, F.D. (2008). A Methodology for Assessing the Value of Knowledge in a Service Parts Supply Chain. IEEE Transactions on Systems, Man and Cybernetics, Part C (Applications and Reviews), 38(3), 446-460. https://doi.org/10.1109/TSMCC.2008.919175

Mentzas, G., Apostolou, D., Kafentzis, K., \& Georgolios, P. (2006). Inter-organizational networks for knowledge sharing and trading. Information Technology and Management, 7(4), 259-276. https://doi.org/10.1007/s10799-006-0276-8

Modi, S.B., \& Mabert, V.A. (2007). Supplier development: Improving supplier performance through knowledge transfer. Journal of Operations Management, 25(1), 42-64. https://doi.org/10.1016/j.jom.2006.02.001 
More, D., \& Basu, P. (2013). Challenges of supply chain finance: A detailed study and a hierarchical model based on the experiences of an Indian firm Dileep. Business Process Management Journal, 19(4), 624-647. https://doi.org/10.1108/BPMJ-09-2012-0093

Muñoz, E., Capón-García, E., Laínez-Aguirre, J.M., Espuña, A., \& Puigjaner, L. (2014). Using mathematical knowledge management to support integrated decision-making in the enterprise. Computers \& Chemical Engineering, 66, 139-150. https://doi.org/10.1016/j.compchemeng.2014.02.026

Muñoz, E., Capón-García, E., Laínez, J.M., Espuña, A., \& Puigjaner, L. (2013). Considering environmental assessment in an ontological framework for enterprise sustainability. Journal of Cleaner Production, 47,149-164. https://doi.org/10.1016/j.jclepro.2012.11.032

Nachiappan, S.P., Gunasekaran, A., \& Jawahar, N. (2007). Knowledge management system for operating parameters in two-echelon VMI supply chains. International Journal of Production Research, 45(11), 2479-2505. https://doi.org/10.1080/00207540601020478

Nagarajan, S., Ganesh, K., \& Sundarakani, B. (2009). Organisational readiness assessment framework and model for knowledge management - application for manufacturing supply chain. International Journal of Electronic Customer Relationship Management, 3(3), 264. https://doi.org/10.1504/IJECRM.2009.027953

Nagati, H., \& Rebolledo, C. (2013). Improving operational performance through knowledge exchange with customers. Production Planning \& Control, 24(8-9), 658-670.

https://doi.org/10.1080/09537287.2012.666843

Nikabadi, M.S. (2014). A framework for technology-based factors for knowledge management in supply chain of auto industry. Vine, 44(3), 375-393. https://doi.org/10.1108/VINE-09-2013-0057

Nikabadi, M.S., \& Zamanloo, S.O.Z. (2012). A Multidimensional Structure for Describing the Influence of Supply Chain Strategies, Business Strategies and Knowledge Management Strategies on Knowledge Sharing in Supply Chain. International Journal of Knowledge Management, 8(4), 50-70.

Nissen, M.E. (1999). Knowledge-based knowledge management in the reengineering domain. Decision Support Systems, 27(1), 47-65. https://doi.org/10.1016/S0167-9236(99)00036-6

Norbis, M., Meixell, M.J., \& Tuggle, F.D. (2013). Modelling security in the maritime supply chain using knowledge constructs. International Journal of Logistics Systems and Management, 15(4), 359. https://doi.org/10.1504/IJLSM.2013.054897

Oke, A., Prajogo, D.I., \& Jayaram, J. (2013). Strengthening the innovation chain: The role of internal innovation climate and strategic relationships with supply chain partners. Journal of Supply Chain Management, 49(4), 43-58. https://doi.org/10.1111/jscm.12031 
Ordoobadi, S.M., \& Wang, S. (2011). A multiple perspectives approach to supplier selection. Industrial Management \& Data Systems, 111(4), 629-648. https://doi.org/10.1108/02635571111133588

Oshri, I., Pan, S.L., \& Newell, S. (2005). Trade-offs between knowledge exploitation and exploration activities. Knowledge Management Research \& Practice, 3(1), 10-23. https://doi.org/10.1057/palgrave.kmrp.8500042

Patil, S.K., \& Kant, R. (2013). A Fuzzy DEMATEL Method to Identify Critical Success Factors of Knowledge Management Adoption in Supply Chain. Journal of Information \& Knowledge Management, 12(3), 1-15. https://doi.org/10.1142/S0219649213500196

Patil, S.K., \& Kant, R. (2014a). A fuzzy AHP-TOPSIS framework for ranking the solutions of Knowledge Management adoption in Supply Chain to overcome its barriers. Expert Systems with Applications, 41(2), 679-693.https://doi.org/10.1016/j.eswa.2013.07.093

Patil, S.K., \& Kant, R. (2014b). A hybrid approach based on fuzzy DEMATEL and FMCDM to predict success of knowledge management adoption in supply chain. Applied Soft Computing, 18, 126-135. https://doi.org/10.1016/j.asoc.2014.01.027

Patil, S.K., \& Kant, R. (2014c). Knowledge management adoption in supply chain: Identifying critical success factors using fuzzy DEMATEL approach. Journal of Modelling in Management, 9(2), 160-178. https://doi.org/10.1108/JM2-08-2012-0025

Patil, S.K., \& Kant, R. (2014d). Ranking the barriers of knowledge management adoption in supply chain using fuzzy AHP method. International Journal of Business Innovation and Research, 8(1), 52-75. https://doi.org/10.1504/IJBIR.2014.058047

Paton, R.A., \& McLaughlin, S. (2008). Services innovation:. Knowledge transfer and the supply chain. European Management Journal, 26(2), 77-83. https://doi.org/10.1016/j.emj.2008.01.004

Paulraj, A., Lado, A.A., \& Chen, I.J. (2008). Inter-organizational communication as a relational competency: Antecedents and performance outcomes in collaborative buyer-supplier relationships. Journal of Operations Management, 26(1), 45-64. https://doi.org/10.1016/j.jom.2007.04.001

Pedroso, M.C., \& Nakano, D. (2009). Knowledge and information flows in supply chains: A study on pharmaceutical companies. International Journal of Production Economics, 122(1), 376-384.

https://doi.org/10.1016/j.ijpe.2009.06.012

Prakash, A., Chan, F.T.S., Liao, H., \& Deshmukh, S.G. (2012). Network optimization in supply chain: A KBGA approach. Decision Support Systems, 52(2), 528-538. https://doi.org/10.1016/j.dss.2011.10.024 
Purwaningrum, F., \& Evers, H.D. (2012). Knowledge flow in the academia-industry collaboration or supply chain linkage? Case study of the automotive industries in the Jababeka Cluster. Procedia -Social and Behavioral Sciences, 52, 62-71. https://doi.org/10.1016/j.sbspro.2012.09.442

Qi, K., \& Chen, W. (2014). Research on green supply chain knowledge sharing mechanism. Energy Education Science and Technology Part A: Energy Science and Research, 32(6), 8077-8086. http://www.silasscience.com

Raisinghani, M.S., \& Meade, L.L. (2005). Strategic decisions in supply-chain intelligence using knowledge management: an analytic-network-process framework. Supply Chain Management: An International Journal, 10(2), 114-121. https://doi.org/10.1108/13598540510589188

Ranganathan, C., Teo, T.S.H., \& Dhaliwal, J. (2011). Web-enabled supply chain management: Key antecedents and performance impacts. International Journal of Information Management, 31(6), 533-545. https://doi.org/10.1016/j.ijinfomgt.2011.02.004

Rao, N.H. (2007). A framework for implementing information and communication technologies in agricultural development in India. Technological Forecasting and Social Change, 74(4), 491-518. https://doi.org/10.1016/j.techfore.2006.02.002

Reychav, I. (2009). Knowledge sharing in a trade show: A learning spiral model. Vine, 39(2), 143-158. https://doi.org/10.1108/03055720910988850

Rollins, M., Pekkarinen, S., \& Mehtälä, M. (2011). Inter-firm customer knowledge sharing in logistics services: an empirical study. International Journal of Physical Distribution \& Logistics Management, 41(10), 956-971. https://doi.org/10.1108/09600031111185239

Rubenstein-Montano, B., Liebowitz, J., Buchwalter, J., McCaw, D., Newman, B., \& Rebeck, K. (2001). A systems thinking framework for knowledge management. Decision Support Systems, 31(1), 5-16. https://doi.org/10.1016/S0167-9236(00)00116-0

Samaddar, S., Nargundkar, S., \& Daley, M. (2006). Inter-organizational information sharing: The role of supply network configuration and partner goal congruence. European Journal of Operational Research, 174(2), 744-765. https://doi.org/10.1016/j.ejor.2005.01.059

Sambasivan, M., Loke, S.P., \& Abidin-Mohamed, Z. (2009). Impact of knowledge management in supply chain management: A study in Malaysian manufacturing companies. Knowledge and Process Management, 16(3), 111-123. https://doi.org/10.1002/kpm.328 
Samuel, K.E., Goury, M.L., Gunasekaran, A., \& Spalanzani, A. (2011). Knowledge management in supply chain: An empirical study from France. The Journal of Strategic Information Systems, 20(3), 283-306. https://doi.org/10.1016/j.jsis.2010.11.001

Sangari, M.S., Hosnavi, R., \& Zahedi, M.R. (2015). The impact of knowledge management processes on supply chain performance: An empirical study. The International Journal of Logistics Management, 26(3), 603-626. https://doi.org/10.1108/IJLM-09-2012-0100

Schoenherr, T., Griffith, D.A., \& Chandra, A. (2015). Knowledge management in supply chains: The role of explicit and tacit knowledge. Journal of Business Economics and Management, 35(2), 121-135. https://doi.org/10.1111/jbl.12042

Schrettle, S., Hinz, A., Scherrer-Rathje, M., \& Friedli, T. (2014). Turning sustainability into action: Explaining firms' sustainability efforts and their impact on firm performance. International Journal of Production Economics, 147(Part A), 73-84. https://doi.org/10.1016/j.ijpe.2013.02.030

Sherwood, A.L., \& Covin, J.G. (2008). Knowledge acquisition in university industry alliances: An empirical investigation from a learning theory perspective. Journal of Product Innovation Management, 25(2), 162-179. https://doi.org/10.1111/j.1540-5885.2008.00292.x

Shih, S.C., Hsu, S.H.Y., Zhu, Z., \& Balasubramanian, S.K. (2012). Knowledge sharing-A key role in the downstream supply chain. Information \& Management, 49(2), 70-80. https://doi.org/10.1016/j.im.2012.01.001

Shunk, D.L., Carter, J.R., Hovis, J., \& Talwar, A. (2007). Electronics industry drivers of intermediation and disintermediation. International Journal of Physical Distribution \& Logistics Management, 37(3), 248-261. https://doi.org/10.1108/09600030710742443

Singh, P.J., \& Power, D. (2014). Innovative knowledge sharing, supply chain integration and firm performance of Australian manufacturing firms. International Journal of Production Research, 52(21), 6416-6433.https://doi.org/10.1080/00207543.2013.859760

Sivakumar, K., \& Roy, S. (2004). Knowledge redundancy in supply chains: a framework. Supply Chain Management: An International Journal, 9(3), 241-249. https://doi.org/10.1108/13598540410544935

Smith, A.D. (2009). Customer relationship management: a look at incentive programmes and their usefulness in selected service firms. International Journal of Business Innovation and Research, 3(1), 1-16. https://doi.org/10.1504/IJBIR.2009.021652

Su, H.Y., Fang, S.C., \& Young, C.S. (2013). Influences of relationship transparency from intellectual capital reporting on supply chain partnerships with suppliers: a field experiment. Supply Chain Management: An International Journal, 18(2), 178-193. https://doi.org/10.1108/13598541311318818 
Sudhindra, S., Ganesh, L.S., \& Arshinder, K. (2014). Classification of supply chain knowledge: A morphological approach. Journal of Knowledge Management, 18(4), 812-823. https://doi.org/10.1108/JKM-122013-0490

Tah, J.H.M., \& Carr, V. (2001). Towards a framework for project risk knowledge management in the construction supply chain. Advances in Engineering Software, 32(10), 835-846.

https://doi.org/10.4203/ccp.58.10.2

Tatham, P., \& Spens, K. (2011). Towards a humanitarian logistics knowledge management system. Disaster Prevention and Management, 20(1), 6-26. https://doi.org/10.1108/09653561111111054

Tatikonda, M.V., \& Stock, G.N. (2003). Product technology transfer in the upstream supply chain. Journal of Product Innovation Management, 20(6), 444-467. https://doi.org/10.1111/1540-5885.00042

Tennant, S., \& Fernie, S. (2013). Organizational learning in construction supply chains. Engineering, Construction and Architectural Management, 20(1), 83-98. https://doi.org/10.1108/09699981311288691

Thomas, R.W., Fugate, B.S., \& Koukova, N.T. (2011). Coping with time pressure and knowledge sharing in buyer-supplier relationships. Journal of Supply Chain Management, 47(3), 22-42. https://doi.org/10.1111/j.1745-493X.2011.03229.x

Thomas, S.P., Thomas, R.W., Manrodt, K.B., \& Rutner, S.M. (2013). An experimental test of negotiation strategy effects on knowledge sharing intentions in buyer-supplier relationships. Journal of Supply Chain Management, 49(2), 96-113. https://doi.org/10.1111/jscm.12004

Tranfield, D., Denyer, D., \& Smart, P. (2003). Towards a methodology for developing evidence-informed management knowledge by means of systematic review. British Journal of Management, 14, 207-222. https://doi.org/10.1111/1467-8551.00375

Tseng, S.M. (2014). The impact of knowledge management capabilities and supplier relationship management on corporate performance. International Journal of Production Economics, 154, 39-47. https://doi.org/10.1016/j.ijpe.2014.04.009

Ulieru, M., Norrie, D., Kremer, R., \& Shen, W. (2000). A multi-resolution collaborative architecture for web-centric global manufacturing. Information Sciences, 127(1), 3-21. https://doi.org/10.1016/S00200255(00)00026-8

Uusipaavalniemi, S., \& Juga, J. (2009). Information integration in maintenance services. International Journal of Productivity and Performance Management, 58(1), 92-110. https://doi.org/10.1108/17410400910921100 
Van Hoof, B. (2014). Organizational learning in cleaner production among Mexican supply networks. Journal of Cleaner Production, 64, 115-124. https://doi.org/10.1016/j.jclepro.2013.07.041

Verma, A., \& Tiwari, M. K. (2009). Role of corporate memory in the global supply chain environment. International Journal of Production Research, 47(19), 5311-5342. https://doi.org/10.1080/00207540801918570

Viswanadham, N., \& Gaonkar, R. (2009). A conceptual and analytical framework for management of integrated knowledge based logistics providers. International Journal of Logistics Systems and Management, 5(1-2), 191-209. https://doi.org/10.1504/IJLSM.2009.021651

Volpato, G., \& Stocchetti, A. (2007). Knowledge management in the automotive supply chain: exploring suppliers' point of view. International Journal of Automotive Technology and Management, 7(2/3), 184-199. https://doi.org/10.1504/IJATM.2007.014974

Wadhwa, S., \& Saxena, A. (2007). Decision knowledge sharing: flexible supply chains in KM context. Production Planning \& Control, 18(5), 436-452. https://doi.org/10.1080/09537280701450661

Wadhwa, S., Saxena, A., \& Bibhushan. (2006). Flexible supply chains: A context for decision knowledge sharing and decision delays. Global Journal of Flexible Systems Management, 7(3-4), 25-39.

Wamba, S.F. (2012). Achieving supply chain integration using RFID technology: The case of emerging intelligent B-to-B e-commerce processes in a living laboratory. Business Process Management Journal, 18(1), 58-81. https://doi.org/10.1108/14637151211215019

Wang, C., Fergusson, C., Perry, D., \& Antony, J. (2008). A conceptual case-based model for knowledge sharing among supply chain members. Business Process Management Journal, 14(2), 147-165.

https://doi.org/10.1108/14637150810864907

Wang, X., Wong, T.N., \& Fan, Z.P. (2013). Ontology-based supply chain decision support for steel manufacturers in China. Expert Systems with Applications, 40(18), 7519-7533.

https://doi.org/10.1016/j.eswa.2013.07.061

Warkentin, M., Sugumaran, V., \& Sainsbury, R. (2012). The role of intelligent agents and data mining in electronic partnership management. Expert Systems with Applications, 39(18), 13277-13288.

https://doi.org/10.1016/j.eswa.2012.05.074

Whitman, L.E., \& Panetto, H. (2006). The missing link: Culture and language barriers to interoperability. Annual Reviews in Control, 30(2), 233-241. https://doi.org/10.1016/j.arcontrol.2006.09.008 
Williams, A.J. (2014). Transporting tacit supply knowledge in competitive environments: a storytelling perspective. International Journal of Procurement Management, 7(5), 622-638.

https://doi.org/10.1504/IJPM.2014.064622

Wong, W.P., \& Wong, K.Y. (2011). Supply chain management, knowledge management capability and their linkages towards firm performance. Business Process Management Journal, 17(6), 940-964. https://doi.org/10.1108/14637151111182701

Woolliscroft, P., Caganova, D., Cambal, M., Holecek, J., \& Pucikova, L. (2013). Implications for optimisation of the automotive supply chain through knowledge management. Procedia CIRP, 7 , 211-216. https://doi.org/10.1016/j.procir.2013.05.036

Worasinchai, L., \& Daneshgar, F. (2012). Identifying knowledge transfer requirement in global organisational contexts. International Journal of Innovation and Learning, 12(4), 353-363.

https://doi.org/10.1504/IJIL.2012.049349

Wrigley, N., Coe, N.M., \& Currah, A. (2005). Globalizing retail: conceptualizing the distribution-based transnational corporation (TNC). Progress in Human Geography, 29(4), 437-457. https://doi.org/10.1191/0309132505ph559oa

Wu, C. (2008). Knowledge creation in a supply chain. Supply Chain Management: An International Journal, 13(3), 241-250. https://doi.org/10.1108/13598540810871280

Wu, D.J. (2001). Software agents for knowledge management: coordination in multi-agent supply chains and auctions. Expert Systems with Applications, 20(1), 51-64. https://doi.org/10.1016/S0957-4174(00)00048-8

Wynn, M., \& Olubanjo, O. (2012). Demand-supply chain management: systems implications in an SME packaging business in the UK. International Journal of Manufacturing Research, 7(2), 198-212. https://doi.org/10.1504/IJMR.2012.046803

Xiuhong, W. (2013). Knowledge Transfer Research in the Supply Chain Based on System Dynamic Model. Journal of Convergence Information Technology, 8(5), 522-529. https://doi.org/10.4156/jcit.vol8.issue5.59

Yam, A.Y.K., Chan, M.F.S., \& Chung, W.W.C. (2007). Networked enterprise: a case study of implementing an information network system for global product development. International Journal, 14(3), 369-386. https://doi.org/10.1108/14635770710753121

Yang, J. (2012a). A structural model of supply chain performance in an emerging economy. International Journal of Production Research, 50(14), 3895-3903. https://doi.org/10.1080/00207543.2011.603373 
Yang, J. (2012b). Harnessing value in knowledge management for performance in buyer-supplier collaboration. International Journal of Production Research, 51(7), 1-8.

https://doi.org/10.1080/00207543.2012.701774

Yang, J., Rui, M., Rauniar, R., Ikem, F.M., \& Xie, H. (2013). Unravelling the link between knowledge management and supply chain integration: an empirical study. International Journal of Logistics Research and Applications, 16(2), 132-143. https://doi.org/10.1080/13675567.2013.804908

Yang, J., Wong, C.W.Y., Lai, K.H., \& Ntoko, A.N. (2009). The antecedents of dyadic quality performance and its effect on buyer-supplier relationship improvement. International Journal of Production Economics, 120(1), 243-251. https://doi.org/10.1016/j.ijpe.2008.07.033

Yazici, H.J. (2012). Buyer perceptions on the buyer-supplier collaborative relationship and performance: a service example. International Journal of Services and Operations Management, 12(2), 165-187.

https://doi.org/10.1504/IJSOM.2012.047104

Ye, Y., Yang, D., Jiang, Z., \& Tong, L. (2008). Ontology-based semantic models for supply chain management. International Journal of Advanced Manufacturing Technology, 37(11-12), 1250-1260. https://doi.org/10.1007/s00170-007-1052-6

Yu, W., Jacobs, M.A., Salisbury, W.D., \& Enns, H. (2013). The effects of supply chain integration on customer satisfaction and financial performance: An organizational learning perspective. International Journal of Production Economics, 146(1), 346-358. https://doi.org/10.1016/j.ijpe.2013.07.023

Zacharia, Z.G., Nix, N.W., \& Lusch, R.F. (2011). Capabilities that enhance outcomes of an episodic supply chain collaboration. Journal of Operations Management, 29(6), 591-603.

https://doi.org/10.1016/j.jom.2011.02.001

Zdravković, M., Panetto, H., Trajanović, M., \& Aubry, A. (2011). An approach for formalising the supply chain operations. Enterprise Information Systems, 5(4), 401-421. https://doi.org/10.1080/17517575.2011.593104

Zernand-Vilson, M., \& Elenurm, T. (2010). Differences in implementing management and organization development directions between domestic and foreign companies in Estonia. Baltic Journal of Management, 5(1), 82-99. https://doi.org/10.1108/17465261011016577

Zhang, M., \& Huo, B. (2013). The impact of dependence and trust on supply chain integration. International Journal of Physical Distribution \& Logistics Management, 43(7), 544-563. 
Zhang, X., Chen, W., Tong, J., \& Liu, X. (2012). Relational mechanisms, market contracts and crossenterprise knowledge trading in the supply chain. Chinese Management Studies, 6(3), 488-508. https://doi.org/10.1108/17506141211259159

Zhu, X., Mukhopadhyay, S.K., \& Kurata, H. (2012). A review of RFID technology and its managerial applications in different industries. Journal of Engineering and Technology Management, 29(1), 152-167. https://doi.org/10.1016/j.jengtecman.2011.09.011

\section{Appendix}

\begin{tabular}{|c|c|}
\hline 1. Author(s) & Adewole, A. \\
\hline Article title & $\begin{array}{l}\text { Developing a strategic framework for efficient and effective optimisation of information in the supply } \\
\text { chains of the UK clothing manufacture industry }\end{array}$ \\
\hline Journal / Year & Supply chain management: An international Journal / 2005 \\
\hline Research method & Interview \\
\hline SCM area & Supply chain strategy \\
\hline KM processes & Transfer \\
\hline 2. Author(s) & Aitken, J., \& Harrison, A. \\
\hline Article title & Supply governance structures for reverse logistics systems \\
\hline Journal / Year & International Journal of Operations \& Production Management / 2013 \\
\hline Research method & Case study \\
\hline SCM area & Reverse logistics \\
\hline KM processes & Storage; Transfer \\
\hline 3. Author(s) & Akhavan, P., Elahi, B., \& Jafari, M. \\
\hline Article title & $\begin{array}{l}\text { A new integrated knowledge model in supplier selection: The case of an Asian automotive supply } \\
\text { chain }\end{array}$ \\
\hline Journal / Year & Education, Business and Society: Contemporary Middle Eastern Issues / 2014 \\
\hline Research method & Survey and Interview \\
\hline SCM area & Procurement / Supplier management \\
\hline KM processes & Creation; Storage; Transfer; Application \\
\hline 4. Author(s) & Al-Karaghouli, W., Ghoneim, A., Sharif, A., \& Dwivedi, Y.K. \\
\hline Article title & $\begin{array}{l}\text { The Effect of Knowledge Management in Enhancing the Procurement Process in the UK Healthcare } \\
\text { Supply Chain }\end{array}$ \\
\hline Journal / Year & Information Systems Management / 2013 \\
\hline Research method & Case study \\
\hline SCM area & Procurement / Supplier management \\
\hline KM processes & Creation; Transfer \\
\hline 5. Author(s) & Al-Mutawah, K., Lee, V., \& Cheung, Y. \\
\hline Article title & $\begin{array}{l}\text { A new multi-agent system framework for tacit knowledge management in manufacturing supply } \\
\text { chains }\end{array}$ \\
\hline Journal / Year & Journal of Intelligent Manufacturing / 2009 \\
\hline Research method & Simulation \\
\hline SCM area & Scheduling \\
\hline
\end{tabular}




\begin{tabular}{|c|c|}
\hline KM processes & Transfer \\
\hline 6. Author(s) & Anbumozhi, V., Gunjima, T., Ananth, A.P., \& Visvanathan, C. \\
\hline Article title & $\begin{array}{l}\text { An assessment of inter-firm networks in a wood biomass industrial cluster: lessons for integrated } \\
\text { policymaking }\end{array}$ \\
\hline Journal / Year & Clean Technologies and Environmental Policy / 2010 \\
\hline Research method & Conceptual model \\
\hline SCM area & Intra and inter-firm relations \\
\hline KM processes & Transfer \\
\hline 7. Author(s) & Angeles, R. \\
\hline Article title & $\begin{array}{l}\text { RFID critical success factors and system deployment outcomes as mitigated by IT infrastructure } \\
\text { integration and supply chain process integration }\end{array}$ \\
\hline Journal / Year & International Journal of Value Chain Management / 2012 \\
\hline Research method & Survey \\
\hline SCM area & Supply chain integration \\
\hline KM processes & Creation \\
\hline 8. Author(s) & Arora, A.S. \\
\hline Article title & $\begin{array}{l}\text { The "organization" as an interdisciplinary learning zone: Using a strategic game to integrate learning } \\
\text { about supply chain management and advertising }\end{array}$ \\
\hline Journal / Year & Learning Organization / 2012 \\
\hline Research method & Simulation \\
\hline SCM area & Supply chain strategy \\
\hline KM processes & Creation; Transfer \\
\hline 9. Author(s) & Bandyopadhyay, S., \& Pathak, P. \\
\hline Article title & Knowledge sharing and cooperation in outsourcing projects-A game theoretical analysis \\
\hline Journal / Year & Decision Support Systems / 2007 \\
\hline Research method & Mathematical model \\
\hline SCM area & Outsourcing \\
\hline KM processes & Transfer \\
\hline 10. Author(s) & Becker, M.C., \& Zirpoli, F. \\
\hline Article title & $\begin{array}{l}\text { Organizing new product development: knowledge hollowing-out and knowledge integration-the } \\
\text { FIAT Auto case. }\end{array}$ \\
\hline Journal / Year & International Journal of Operations and Production Management /2003 \\
\hline Research method & Case study \\
\hline SCM area & Product development \\
\hline KM processes & Creation \\
\hline 11. Author(s) & Beske, P., Land, A., \& Seuring, S \\
\hline Article title & $\begin{array}{l}\text { Sustainable supply chain management practices and dynamic capabilities in the food industry: A } \\
\text { critical analysis of the literature. }\end{array}$ \\
\hline Journal / Year & International Journal of Production Economics / 2014 \\
\hline Research method & Other \\
\hline SCM area & Sustainable supply chain \\
\hline KM processes & Creation \\
\hline 12. Author(s) & Biotto, M., De Toni, A.F., \& Nonino, F. \\
\hline Article title & $\begin{array}{l}\text { Knowledge and cultural diffusion along the supply chain as drivers of product quality improvement: } \\
\text { The illycaffè case study. }\end{array}$ \\
\hline
\end{tabular}




\begin{tabular}{|c|c|}
\hline Journal / Year & International Journal of Logistics Management / 2012 \\
\hline Research method & Case study \\
\hline SCM area & Supply chain learning \\
\hline KM processes & Transfer \\
\hline 13. Author(s) & Bjurklo, M., Edvardsson, B., \& Gebauer, H. \\
\hline Article title & The role of competence in initiating the transition from products to service. \\
\hline Journal / Year & Managing Service Quality / 2009 \\
\hline Research method & Case study \\
\hline SCM area & Customer service management \\
\hline KM processes & Creation; Transfer \\
\hline 14. Author(s) & Blome, C., Schoenherr, T., \& Eckstein, D. \\
\hline Article title & $\begin{array}{l}\text { The impact of knowledge transfer and complexity on supply chain flexibility: A knowledge-based } \\
\text { view }\end{array}$ \\
\hline Journal / Year & International Journal of Production Economics / 2014 \\
\hline Research method & Survey \\
\hline SCM area & Procurement / Supplier management \\
\hline KM processes & Transfer \\
\hline 15. Author(s) & Braziotis, C., \& Tannock, J. \\
\hline Article title & Building the extended enterprise: Key collaboration factors \\
\hline Journal / Year & International Journal of Logistics Management / 2011 \\
\hline Research method & Interview \\
\hline SCM area & Supply chain collaboration \\
\hline KM processes & Transfer \\
\hline 16. Author(s) & Breite, R., Koskinen, K.U. \\
\hline Article title & Supply chain as an autopoietic learning system \\
\hline Journal / Year & Supply Chain Management / 2014 \\
\hline Research method & Conceptual model \\
\hline SCM area & Supply chain learning \\
\hline KM processes & Creation \\
\hline 17. Author(s) & Briscoe, G., Dainty, A.R., \& Millett, S. \\
\hline Article title & Construction supply chain partnerships: skills, knowledge and attitudinal requirements. \\
\hline Journal / Year & European Journal of Purchasing and Supply Management / 2001 \\
\hline Research method & Interview \\
\hline SCM area & Supply chain integration \\
\hline KM processes & Creation; Transfer \\
\hline 18. Author(s) & Cadden, T., Marshall, D., \& Cao, G. \\
\hline Article title & Opposites attract: organisational culture and supply chain performance. \\
\hline Journal / Year & Supply Chain Management: an International Journal / 2013 \\
\hline Research method & Survey \\
\hline SCM area & Supply chain relationship \\
\hline KM processes & Transfer \\
\hline 19. Author(s) & Cai, S., Goh, M., De Souza, R., \& Li, G. \\
\hline Article title & Knowledge sharing in collaborative supply chains: Twin effects of trust and power \\
\hline
\end{tabular}




\begin{tabular}{|c|c|}
\hline Journal / Year & International Journal of Production Research / 2013 \\
\hline Research method & Survey \\
\hline SCM area & Supply chain relationship \\
\hline KM processes & Transfer \\
\hline 20. Author(s) & Cantor, D.E., Blackhurst, J., Pan, M., \& Crum, M. \\
\hline Article title & $\begin{array}{l}\text { Examining the role of stakeholder pressure and knowledge management on supply chain risk and } \\
\text { demand responsiveness }\end{array}$ \\
\hline Journal / Year & International Journal of Logistics Management / 2014 \\
\hline Research method & Survey \\
\hline SCM area & Risk management \\
\hline KM processes & Transfer \\
\hline 21. Author(s) & Cao, M., Vonderembse, M.A., Zhang, Q., \& Ragu-Nathan, T.S. \\
\hline Article title & Supply chain collaboration: Conceptualisation and instrument development \\
\hline Journal / Year & International Journal of Production Research / 2010 \\
\hline Research method & Conceptual model \\
\hline SCM area & Supply chain collaboration \\
\hline KM processes & Creation \\
\hline 22. Author(s) & Capó-Vicedo, J., Mula, J., \& Capó, J. \\
\hline Article title & A social network-based organizational model for improving knowledge management in supply chains \\
\hline Journal / Year & Supply Chain Management / 2011 \\
\hline Research method & Case study \\
\hline SCM area & Intra and inter-firm relations \\
\hline KM processes & Transfer \\
\hline 23. Author(s) & Cerruti, C., \& Delbufalo, E. \\
\hline Article title & $\begin{array}{l}\text { International sourcing effectiveness in the fashion industry: the experience of Italian industrial } \\
\text { districts }\end{array}$ \\
\hline Journal / Year & International Journal of Globalisation and Small Business / 2009 \\
\hline Research method & Survey \\
\hline SCM area & Risk management \\
\hline KM processes & Transfer \\
\hline 24. Author(s) & Cervellon, M.C., \& Wernerfelt, A.S. \\
\hline Article title & $\begin{array}{l}\text { Knowledge sharing among green fashion communities online: Lessons for the sustainable supply } \\
\text { chain. }\end{array}$ \\
\hline Journal / Year & Journal of Fashion Marketing and Management / 2012 \\
\hline Research method & Conceptual model \\
\hline SCM area & Sustainable supply chain \\
\hline KM processes & Transfer \\
\hline 25. Author(s) & Cha, H.S., Pingry, D.E., \& Thatcher, M.E. \\
\hline Article title & $\begin{array}{l}\text { Managing the knowledge supply chain: An organizational learning model of information technology } \\
\text { offshore outsourcing }\end{array}$ \\
\hline Journal / Year & MIS Quarterly / 2008 \\
\hline Research method & Mathematical model \\
\hline SCM area & Outsourcing \\
\hline KM processes & Transfer \\
\hline
\end{tabular}




\begin{tabular}{|c|c|}
\hline 26. Author(s) & Chan, Y.L., Cheung, C.F., Lee, W.B., \& Kwok, S.K. \\
\hline Article title & Knowledge-based simulation and analysis of supply chain performance \\
\hline Journal / Year & International Journal of Computer Integrated Manufacturing / 2006 \\
\hline Research method & Simulation \\
\hline SCM area & Inventory management \\
\hline KM processes & Creation; Storage; Transfer; Application \\
\hline 27. Author(s) & Chandra, C., \& Kamrani, A.K. \\
\hline Article title & Knowledge management for consumer-focused product design \\
\hline Journal / Year & Journal of Intelligent Manufacturing / 2003 \\
\hline Research method & Case study \\
\hline SCM area & Product development \\
\hline KM processes & Creation; Storage; Transfer; Application \\
\hline 28. Author(s) & Chandra, C., \& Tumanyan, A. \\
\hline Article title & Organization and problem ontology for supply chain information support system. \\
\hline Journal / Year & Data and Knowledge Engineering / 2007 \\
\hline Research method & Case study \\
\hline SCM area & Scheduling \\
\hline $\mathrm{KM}$ processes & Creation; Storage; Transfer; Application \\
\hline 29. Author(s) & Chen, D.Q., Preston, D.S., \& Xia, W. \\
\hline Article title & Enhancing hospital supply chain performance: A relational view and empirical test \\
\hline Journal / Year & Journal of Operations Management / 2013 \\
\hline Research method & Survey \\
\hline SCM area & Supply chain integration \\
\hline KM processes & Transfer \\
\hline 30. Author(s) & Chen, H.H., Kang, H.Y., Xing, X., Lee, A. H.I., \& Tong, Y. \\
\hline Article title & $\begin{array}{l}\text { Developing new products with knowledge management methods and process development } \\
\text { management in a network }\end{array}$ \\
\hline Journal / Year & Computers in Industry / 2008 \\
\hline Research method & Other \\
\hline SCM area & Product development \\
\hline KM processes & Creation \\
\hline 31. Author(s) & Chen, Y.J., Chen, Y.M., \& Wu, M.S. \\
\hline Article title & $\begin{array}{l}\text { Development of an Ontology-based Expert Recommendation System for Product Empirical } \\
\text { Knowledge Consultation }\end{array}$ \\
\hline Journal / Year & Concurrent Engineering: Research and Applications / 2010 \\
\hline Research method & Other \\
\hline SCM area & Product development \\
\hline KM processes & Creation; Storage; Transfer; Application \\
\hline 32. Author(s) & Chen, Y, \& Li, L \\
\hline Article title & Deriving information from CRM for knowledge management - A note on a commercial bank \\
\hline Journal / Year & Systems Research and Behavioral Science / 2006 \\
\hline Research method & Case study \\
\hline SCM area & Customer service management \\
\hline KM processes & Creation \\
\hline
\end{tabular}




\begin{tabular}{|c|c|}
\hline 33. Author(s) & Chen, Y.-H., Lin, T.-P., \& Yen, D.C. \\
\hline Article title & How to facilitate inter-organizational knowledge sharing: The impact of trust \\
\hline Journal / Year & Information and Management / 2014 \\
\hline Research method & Survey \\
\hline SCM area & Intra and inter-firm relations \\
\hline KM processes & Transfer \\
\hline 34. Author(s) & Cheng, H.L. \\
\hline Article title & $\begin{array}{l}\text { Seeking knowledge or gaining legitimacy? Role of social networks on new practice adoption by OEM } \\
\text { suppliers. }\end{array}$ \\
\hline Journal / Year & Journal of Business Research / 2010 \\
\hline Research method & Survey \\
\hline SCM area & Customer relationship management \\
\hline KM processes & Creation; Transfer \\
\hline 35. Author(s) & Cheng, J.H., Yeh, C.H., \& Tu, C.W. \\
\hline Article title & Trust and knowledge sharing in green supply chains. \\
\hline Journal / Year & Supply Chain Management: An International Journal / 2008 \\
\hline Research method & Survey \\
\hline SCM area & Green supply chain \\
\hline KM processes & Transfer \\
\hline 36. Author(s) & Cheung, C.F., Cheung, C.M., Kwok, S.K. \\
\hline Article title & A Knowledge-based Customization System for Supply Chain Integration \\
\hline Journal / Year & Expert Systems with Applications / 2012 \\
\hline Research method & Case study \\
\hline SCM area & Supply chain integration \\
\hline KM processes & Creation; Storage; Transfer; Application \\
\hline 37. Author(s) & Cheung, M.S., \& Myers, M.B \\
\hline Article title & Managing knowledge sharing networks in global supply chains. \\
\hline Journal / Year & International Journal of Management and Decision Making / 2008 \\
\hline Research method & Case study \\
\hline SCM area & Global supply chain \\
\hline KM processes & Transfer \\
\hline 38. Author(s) & Cheung, M.S., Myers, M.B., \& Mentzer, J.T. \\
\hline Article title & $\begin{array}{l}\text { The value of relational learning in global buyer-supplier exchanges: a dyadic perspective an pie-sharing } \\
\text { premise. }\end{array}$ \\
\hline Journal / Year & Strategic Management Journal / 2011 \\
\hline Research method & Survey \\
\hline SCM area & Global supply chain \\
\hline KM processes & Transfer \\
\hline 39. Author(s) & Cheung, M.S., Myers, M.B., \& Mentzer, J.T. \\
\hline Article title & Does relationship learning lead to relationship value? A cross-national supply chain investigation \\
\hline Journal / Year & Journal of Operations Management / 2010 \\
\hline Research method & Survey \\
\hline SCM area & Intra and inter-firm relations \\
\hline KM processes & Transfer \\
\hline
\end{tabular}




\begin{tabular}{|c|c|}
\hline 40. Author(s) & Chirumalla, $\mathrm{K}$. \\
\hline Article title & Managing Knowledge for Product-Service System innovation The Role of Web 2.0 Technologies \\
\hline Journal / Year & Research Technology Management / 2013 \\
\hline Research method & Survey and Interview \\
\hline SCM area & Product development \\
\hline KM processes & Creation; Storage; Transfer; Application \\
\hline 41. Author(s) & Choi. T.Y., Budny. J., \& Wank. N. \\
\hline Article title & Intellectual property management: A knowledge supply chain perspective \\
\hline Journal / Year & Business Horizons / 2004 \\
\hline Research method & Case study \\
\hline SCM area & Outsourcing \\
\hline KM processes & Transfer \\
\hline 42. Author(s) & Chong, A.Y.L., \& Bai, R. \\
\hline Article title & Predicting open IOS adoption in SMEs: An integrated SEM-neural network approach \\
\hline Journal / Year & Expert Systems with Applications / 2014 \\
\hline Research method & Case study \\
\hline SCM area & Supply chain integration \\
\hline KM processes & Creation; Transfer \\
\hline 43. Author(s) & Chong, A.Y.L., Chan, F.T.S., Goh, M., \& Tiwari, M.K. \\
\hline Article title & $\begin{array}{l}\text { Do interorganisational relationships and knowledge-management practices enhance collaborative } \\
\text { commerce adoption? }\end{array}$ \\
\hline Journal / Year & International Journal of Production Research / 2013 \\
\hline Research method & Survey \\
\hline SCM area & Intra and inter-firm relations \\
\hline KM processes & Creation; Transfer; Application \\
\hline 44. Author(s) & Chow, H.K.H., Choy, K.L., \& Lee, W.B. \\
\hline Article title & Knowledge management approach in build-to-order supply chains \\
\hline Journal / Year & Industrial Management \& Data Systems / 2007 \\
\hline Research method & Review \\
\hline 45. Author(s) & Chong, A.Y.L., Ooi, K.B., Bao, H., \& Lin, B. \\
\hline Article title & $\begin{array}{l}\text { Can e-business adoption be influenced by knowledge management? An empirical analysis of } \\
\text { Malaysian SMEs }\end{array}$ \\
\hline Journal / Year & Journal of Knowledge Management / 2014 \\
\hline Research method & Survey \\
\hline SCM area & Decision-making \\
\hline KM processes & Creation; Application \\
\hline 46. Author(s) & Choy, K.L., Tan, K.H., \& Chan, F.T.S. \\
\hline Article title & Design of an intelligent supplier knowledge management system - an integrative approach \\
\hline Journal / Year & Journal of Engineering Manufacture / 2007 \\
\hline Research method & Case study \\
\hline SCM area & Procurement / Supplier management \\
\hline KM processes & Creation; Storage; Transfer; Application \\
\hline 47. Author(s) & Christopher, M., \& Gaudenzi, B. \\
\hline Article title & Exploiting knowledge across networks through reputation management \\
\hline
\end{tabular}




\begin{tabular}{|c|c|}
\hline Journal / Year & Industrial Marketing Management / 2009 \\
\hline Research method & Conceptual model \\
\hline SCM area & Supply chain network \\
\hline KM processes & Transfer \\
\hline 48. Author(s) & Collins, J.D., Worthington, W.J., Reyes, P.M., \& Romero, M. \\
\hline Article title & Knowledge management, supply chain technologies, and firm performance \\
\hline Journal / Year & Management Research Review / 2010 \\
\hline Research method & Conceptual model \\
\hline SCM area & Supply chain strategy \\
\hline KM processes & Creation \\
\hline 49. Author(s) & Corso, M., Dogan, S.F., Mogre, R., \& Perego, A. \\
\hline Article title & The role of knowledge management in supply chains: evidence from the Italian food industry. \\
\hline Journal / Year & International Journal of Networking and Virtual Organisations / 2010 \\
\hline Research method & Conceptual model \\
\hline SCM area & Supply chain collaboration \\
\hline KM processes & Transfer \\
\hline 50. Author(s) & Corso, M., Martini, A., Paolucci, E., \& Pellegrini, L. \\
\hline Article title & Knowledge management in product innovation: an interpretative review. \\
\hline Journal / Year & International Journal of Management Reviews / 2001 \\
\hline Research method & Conceptual model \\
\hline SCM area & Product development \\
\hline KM processes & Creation; Transfer \\
\hline 51. Author(s) & Corso, M., \& Paolucci, E. \\
\hline Article title & $\begin{array}{l}\text { Fostering innovation and knowledge transfer in product development through information } \\
\text { technology. }\end{array}$ \\
\hline Journal / Year & International Journal of Technology Management / 2001 \\
\hline Research method & Survey \\
\hline SCM area & Product development \\
\hline KM processes & Transfer \\
\hline 52. Author(s) & Craighead, C.W., Hult, G.T.M., \& Ketchen Jr., D.J. \\
\hline Article title & $\begin{array}{l}\text { The effects of innovation-cost strategy, knowledge and action in the supply chain on firm } \\
\text { performance }\end{array}$ \\
\hline Journal / Year & Journal of Operations Management / 2009 \\
\hline Research method & Survey \\
\hline SCM area & Supply chain strategy \\
\hline KM processes & Transfer \\
\hline 53. Author(s) & Daghfous, A. \\
\hline Article title & Absorptive capacity and innovative enterprise systems: A two-level framework \\
\hline Journal / Year & International Journal of Innovation and Learning / 2007 \\
\hline Research method & Conceptual model \\
\hline SCM area & Supply chain learning \\
\hline KM processes & Creation; Storage; Transfer; Application \\
\hline 54. Author(s) & de Vries, E.J., \& Brijder, H.G. \\
\hline Article title & Knowledge management in hybrid supply channels: a case study \\
\hline
\end{tabular}




\begin{tabular}{|c|c|}
\hline Journal / Year & International Journal of Technology Management / 2000 \\
\hline Research method & Case study \\
\hline SCM area & Supply chain strategy \\
\hline KM processes & Transfer \\
\hline 55. Author(s) & Desouza, K.C., Chattaraj, A., \& Kraft, G. \\
\hline Article title & Supply chain perspectives to knowledge management: research propositions. \\
\hline Journal / Year & Journal of knowledge Management / 2003 \\
\hline Research method & Conceptual model \\
\hline SCM area & Customer relationship management \\
\hline KM processes & Creation; Transfer; Application \\
\hline 56. Author(s) & Douligeris, C., \& Tilipakis, N. \\
\hline Article title & A knowledge management paradigm in the supply chain \\
\hline Journal / Year & EuroMed Journal of Business / 2006 \\
\hline Research method & Conceptual model \\
\hline SCM area & Customer service management \\
\hline KM processes & Creation; Storage; Transfer; Application \\
\hline 57. Author(s) & Duanmu, J.L., \& Fai, F.M. \\
\hline Article title & A processual analysis of knowledge transfer: From foreign MNEs to Chinese suppliers \\
\hline Journal / Year & International Business Review / 2007 \\
\hline Research method & Case study \\
\hline SCM area & Procurement / Supplier management \\
\hline KM processes & Creation; Transfer \\
\hline 58. Author(s) & Dyer, B., \& Ha-Brookshire, J.E. \\
\hline Article title & Apparel import intermediaries' secrets to success; Redefining success in a hyper-dynamic environment \\
\hline Journal / Year & Journal of Fashion Marketing and Management / 2008 \\
\hline Research method & Interview \\
\hline SCM area & Import/export requirements \\
\hline KM processes & Creation \\
\hline 59. Author(s) & Eng, T.Y. \\
\hline Article title & $\begin{array}{l}\text { An investigation into the mediating role of cross-functional coordination on the linkage between } \\
\text { organizational norms and SCM performance. }\end{array}$ \\
\hline Journal / Year & Industrial Marketing Management / 2006 \\
\hline Research method & Survey \\
\hline SCM area & Supply chain collaboration \\
\hline KM processes & Transfer \\
\hline 60. Author(s) & Esper, T.L., Ellinger, A.E., Stank, T.P., Flint, D.J., \& Moon, M. \\
\hline Article title & $\begin{array}{l}\text { Demand and supply integration: A conceptual framework of value creation through knowledge } \\
\text { management }\end{array}$ \\
\hline Journal / Year & Journal of the Academy of Marketing Science / 2010 \\
\hline Research method & Conceptual model \\
\hline SCM area & Supply chain integration \\
\hline KM processes & Creation; Transfer \\
\hline 61. Author(s) & Fahey, L., Srivastava, R., Sharon, J.S., \& Smith, D.E. \\
\hline Article title & Linking e-business and operating processes: The role of knowledge management \\
\hline
\end{tabular}




\begin{tabular}{|c|c|}
\hline Journal / Year & Ibm Systems Journal / 2001 \\
\hline Research method & Other \\
\hline SCM area & Customer relationship management \\
\hline KM processes & Creation \\
\hline 62. Author(s) & Fathallah, A., Stal-Le Cardinal, J., Ermine, J.L., \& Bocquet, J.C. \\
\hline Article title & $\begin{array}{l}\text { Enterprise modelling: Building a product lifecycle management model as a component of the } \\
\text { integrated vision of the enterprise }\end{array}$ \\
\hline Journal / Year & International Journal on Interactive Design and Manufacturing / 2010 \\
\hline Research method & Conceptual model \\
\hline SCM area & Customer relationship management \\
\hline KM processes & Creation; Transfer; Application \\
\hline 63. Author(s) & Filieri, R., \& Alguezaui, S. \\
\hline Article title & Extending the enterprise for improved innovation. \\
\hline Journal / Year & Journal of Business Strategy / 2012 \\
\hline Research method & Conceptual model \\
\hline SCM area & Supply chain strategy \\
\hline KM processes & Transfer \\
\hline 64. Author(s) & Fugate, B.S., Autry, C.W., Davis-Sramek, B., \& Germain, R.N. \\
\hline Article title & $\begin{array}{l}\text { Does knowledge management facilitate logistics-based differentiation? the effect of global } \\
\text { manufacturing reach }\end{array}$ \\
\hline Journal / Year & International Journal of Production Economics / 2012 \\
\hline Research method & Survey \\
\hline SCM area & Logistics management \\
\hline KM processes & Creation; Transfer \\
\hline 65. Author(s) & Fugate, B.S., Mentzer, J.T., \& Flint, D.J. \\
\hline Article title & The role of logistics in market orientation \\
\hline Journal / Year & Journal of Business Logistics / 2008 \\
\hline Research method & Interview \\
\hline SCM area & Logistics management \\
\hline KM processes & Creation; Transfer \\
\hline 66. Author(s) & Fugate, B.S., Stank, T.P., \& Mentzer, J.T. \\
\hline Article title & Linking improved knowledge management to operational and organizational performance \\
\hline Journal / Year & Journal of Operations Management / 2009 \\
\hline Research method & Survey and Interview \\
\hline SCM area & Logistics management \\
\hline KM processes & Creation; Transfer \\
\hline 67. Author(s) & Gambetti, R.C., \& Giovanardi, M. \\
\hline Article title & Re-visiting the supply chain: a communication perspective. \\
\hline Journal / Year & Corporate Communications: An International Journal / 2013 \\
\hline Research method & Conceptual model \\
\hline SCM area & Supply chain strategy \\
\hline KM processes & Transfer \\
\hline 68. Author(s) & Gelderman, C.J., \& Semeijn, J. \\
\hline Article title & Managing the global supply base through purchasing portfolio management. \\
\hline
\end{tabular}




\begin{tabular}{|c|c|}
\hline Journal / Year & Journal of Purchasing and Supply Management / 2006 \\
\hline $\begin{array}{l}\text { Methodological } \\
\text { approach }\end{array}$ & Case study \\
\hline $\begin{array}{l}\text { Supply chain } \\
\text { management area }\end{array}$ & Global supply chain \\
\hline $\begin{array}{l}\text { Knowledge } \\
\text { management } \\
\text { processes }\end{array}$ & Creation; Transfer \\
\hline 69. Author(s) & Giunipero, L., Handfield, R.B., \& Eltantawy, R. \\
\hline Article title & Supply management's evolution: key skill sets for the supply manager of the future \\
\hline Journal / Year & International Journal of Operations \& Production Management / 2006 \\
\hline Research method & Survey and Interview \\
\hline SCM area & Procurement / Supplier management \\
\hline KM processes & Creation \\
\hline 70. Author(s) & Glisby, M., \& Holden, N. \\
\hline Article title & $\begin{array}{l}\text { Applying knowledge management concepts to the supply chain: How a Danish firm achieved a } \\
\text { remarkable breakthrough in Japan }\end{array}$ \\
\hline Journal / Year & Academy of Management Executive / 2005 \\
\hline Research method & Conceptual model \\
\hline SCM area & Supply chain strategy \\
\hline KM processes & Creation; Transfer \\
\hline 71. Author(s) & Gunasekaran, A., \& Ngai, E.W.T. \\
\hline Article title & Knowledge management in 21st century manufacturing \\
\hline Journal / Year & International Journal of Production Research / 2007 \\
\hline Research method & Review \\
\hline 72. Author(s) & Gupta, V.K. \\
\hline Article title & $\begin{array}{l}\text { Flexible strategic framework for KM factors with the perspective of continuity and change: Study of } \\
\text { supply chain of MNCs in electrical and lighting industry }\end{array}$ \\
\hline Journal / Year & International Journal of Value Chain Management / 2012 \\
\hline Research method & Case study \\
\hline SCM area & Supply chain strategy \\
\hline KM processes & Creation; Transfer \\
\hline 73. Author(s) & Halley, A., Nollet, J., Beaulieu, M., Roy, J., \& Bigras, Y. \\
\hline Article title & $\begin{array}{l}\text { The impact of the supply chain on core competencies and knowledge management: Directions for } \\
\text { future research }\end{array}$ \\
\hline Journal / Year & International Journal of Technology Management / 2010 \\
\hline Research method & Conceptual model \\
\hline SCM area & Supply chain integration \\
\hline KM processes & Creation; Transfer \\
\hline 74. Author(s) & Haug, A. \\
\hline Article title & Improving the design phase through interorganisational product knowledge models \\
\hline Journal / Year & International Journal of Production Research / 2013 \\
\hline Research method & Case study \\
\hline SCM area & Supply chain integration \\
\hline KM processes & Creation; Transfer \\
\hline
\end{tabular}




\begin{tabular}{|c|c|}
\hline 75. Author(s) & He, Q., Ghobadian, A., \& Gallear, D. \\
\hline Article title & Knowledge acquisition in supply chain partnerships: The role of power \\
\hline Journal / Year & International Journal of Production Economics / 2013 \\
\hline Research method & Interview \\
\hline SCM area & Supply chain partnership \\
\hline KM processes & Creation; Transfer \\
\hline 76. Author(s) & Hedtrich, F., Loy, J.P., \& Müller, R.A. \\
\hline Article title & Prediction markets: a powerful tool for supply network management? \\
\hline Journal / Year & British Food Journal / 2009 \\
\hline Research method & Conceptual model \\
\hline SCM area & Decision-making \\
\hline KM processes & Transfer \\
\hline 77. Author(s) & Hernández-Espallardo, M., Rodríguez-Orejuela, A., \& Sánchez-Pérez, M. \\
\hline Article title & Inter-organizational governance, learning and performance in supply chains \\
\hline Journal / Year & Supply Chain Management / 2010 \\
\hline Research method & Case study \\
\hline SCM area & Intra and inter-firm relations \\
\hline KM processes & Transfer \\
\hline 78. Author(s) & Huang, C.C., \& Lin, S.H. \\
\hline Article title & Sharing knowledge in a supply chain using the semantic web. \\
\hline Journal / Year & Expert Systems with Applications / 2010 \\
\hline Research method & Case study \\
\hline SCM area & Supply chain interoperability \\
\hline KM processes & Creation; Transfer \\
\hline 79. Author(s) & Huang, T.T.A., Stewart, R.A., \& Chen, L. \\
\hline Article title & $\begin{array}{l}\text { Identifying key enablers to improve business performance in Taiwanese electronic manufacturing } \\
\text { companies. }\end{array}$ \\
\hline Journal / Year & International Journal of Operations and Production Management / 2010 \\
\hline Research method & Survey \\
\hline SCM area & Procurement / Supplier management \\
\hline KM processes & Transfer \\
\hline 80. Author(s) & Hult, G.T.M., Ketchen, D.J., \& Arrfelt, M. \\
\hline Article title & $\begin{array}{l}\text { Strategic supply chain management: improving performance through a culture of competitiveness and } \\
\text { knowledge development. }\end{array}$ \\
\hline Journal / Year & Strategic Management Journal / 2007 \\
\hline Research method & Survey \\
\hline SCM area & Supply chain strategy \\
\hline $\mathrm{KM}$ processes & Creation; Storage; Transfer; Application \\
\hline 81. Author(s) & Hult, G.T.M., Ketchen Jr, D.J., Cavusgil, S.T., \& Calantone, R.J \\
\hline Article title & Knowledge as a strategic resource in supply chains. \\
\hline Journal / Year & Journal of Operations Management / 2006 \\
\hline Research method & Survey \\
\hline SCM area & Supply chain strategy \\
\hline KM processes & Creation; Transfer; Application \\
\hline
\end{tabular}




\begin{tabular}{|c|c|}
\hline 82. Author(s) & Hung, S.W., Chen, P.C., \& Chung, C.F. \\
\hline Article title & $\begin{array}{l}\text { Gaining or losing? The social capital perspective on supply chain members' knowledge sharing of } \\
\text { green practices. }\end{array}$ \\
\hline Journal / Year & Technology Analysis and Strategic Management / 2014 \\
\hline Research method & Survey \\
\hline SCM area & Green supply chain \\
\hline KM processes & Transfer \\
\hline 83. Author(s) & Im, G., \& Rai, A. \\
\hline Article title & Knowledge sharing ambidexterity in long-term interorganizational relationships. \\
\hline Journal / Year & Management Science / 2008 \\
\hline Research method & Survey \\
\hline SCM area & Intra and inter-firm relations \\
\hline KM processes & Creation; Storage; Transfer; Application \\
\hline 84. Author(s) & Irani, Z., Sharif, A., Kamal, M.M., \& Love, P.E.D. \\
\hline Article title & Visualising a knowledge mapping of information systems investment evaluation \\
\hline Journal / Year & Expert Systems with Applications / 2014 \\
\hline Research method & Simulation \\
\hline SCM area & Purchasing \\
\hline KM processes & Creation; Storage; Transfer; Application \\
\hline 85. Author(s) & Jayaram, J., \& Pathak, S. \\
\hline Article title & A holistic view of knowledge integration in collaborative supply chains \\
\hline Journal / Year & International Journal of Production Research / 2013 \\
\hline Research method & Survey \\
\hline SCM area & Product development \\
\hline KM processes & Transfer; Application \\
\hline 86. Author(s) & Jean, R.J., Sinkovics, R.R., \& Hiebaum, T.P. \\
\hline Article title & $\begin{array}{l}\text { The Effects of Supplier Involvement and Knowledge Protection on Product Innovation in } \\
\text { Customer-Supplier Relationships: A Study of Global Automotive Suppliers in China }\end{array}$ \\
\hline Journal / Year & Journal of Product Innovation Management / 2014 \\
\hline Research method & Survey and Interview \\
\hline SCM area & Global supply chain \\
\hline KM processes & Creation \\
\hline 87. Author(s) & Jüttner, U., \& Maklan, S. \\
\hline Article title & Supply chain resilience in the global financial crisis: an empirical study \\
\hline Journal / Year & Supply Chain Management: An International Journal / 2011 \\
\hline Research method & Case study \\
\hline SCM area & Risk management \\
\hline $\mathrm{KM}$ processes & Creation \\
\hline 88. Author(s) & Kai, Q., Wei, C., \& Meng-Lin, B. \\
\hline Article title & Green supply chain knowledge sharing mechanism based on principal-agent theory \\
\hline Journal / Year & Journal of Chemical and Pharmaceutical Research / 2014 \\
\hline Research method & Conceptual model \\
\hline SCM area & Green supply chain \\
\hline KM processes & Transfer \\
\hline
\end{tabular}




\begin{tabular}{|c|c|}
\hline 89. Author(s) & Kanat, S., \& Atilgan, T. \\
\hline Article title & Effects of knowledge management on supply chain management in the clothing sector: Turkish case \\
\hline Journal / Year & Fibres and Textiles in Eastern Europe / 2014 \\
\hline Research method & Survey \\
\hline SCM area & Import/export requirements \\
\hline KM processes & Transfer \\
\hline 90. Author(s) & Kant, R., \& Singh, M.D. \\
\hline Article title & Knowledge management implementation in supply chains: A strategic plan \\
\hline Journal / Year & International Journal of Business Information Systems / 2009 \\
\hline Research method & Case study \\
\hline SCM area & Supply chain strategy \\
\hline KM processes & Creation; Storage; Transfer; Application \\
\hline 91. Author(s) & Kayakutlu, G., \& Büyüközkan, G. \\
\hline Article title & Effective supply value chain based on competence success \\
\hline Journal / Year & Supply Chain Management / 2010 \\
\hline Research method & Case study \\
\hline SCM area & Decision-making \\
\hline KM processes & Transfer \\
\hline 92. Author(s) & Ke, W., \& Wei, K.K \\
\hline Article title & $\begin{array}{l}\text { Factors affecting trading partners' knowledge sharing: Using the lens of transaction cost economics } \\
\text { and socio-political theories }\end{array}$ \\
\hline Journal / Year & Electronic Commerce Research and Applications / 2007 \\
\hline Research method & Interview \\
\hline SCM area & Supply chain partnership \\
\hline KM processes & Transfer \\
\hline 93. Author(s) & Kiessling, T., Harvey, M., \& Moeller, M. \\
\hline Article title & Supply-chain corporate venturing through acquisition: Key management team retention \\
\hline Journal / Year & Journal of World Business / 2012 \\
\hline Research method & Survey \\
\hline SCM area & Intra and inter-firm relations \\
\hline KM processes & Transfer \\
\hline 94. Author(s) & Kim, K.K., Umanath, N.S., Kim, J.Y., Ahrens, F., \& Kim B. \\
\hline Article title & Knowledge complementarity and knowledge exchange in supply channel relationships \\
\hline Journal / Year & International Journal of Information Management / 2012 \\
\hline Research method & Interview \\
\hline SCM area & Intra and inter-firm relations \\
\hline KM processes & Transfer \\
\hline 95. Author(s) & Koh, S.C.L., \& Tan, K.H. \\
\hline Article title & Translating knowledge of supply chain uncertainty into business strategy and actions \\
\hline Journal / Year & Journal of Manufacturing Technology Management / 2006 \\
\hline Research method & Survey \\
\hline SCM area & Decision-making \\
\hline KM processes & Transfer \\
\hline
\end{tabular}




\begin{tabular}{|c|c|}
\hline 96. Author(s) & Kovács, G., \& Spens, K. \\
\hline Article title & Knowledge sharing in relief supply chains \\
\hline Journal / Year & International Journal of Networking and Virtual Organisations / 2010 \\
\hline Research method & Conceptual model \\
\hline SCM area & Humanitarian logistics \\
\hline KM processes & Transfer \\
\hline 97. Author(s) & Kumar, S. \\
\hline Article title & A knowledge based reliability engineering approach to manage product safety and recalls \\
\hline Journal / Year & Expert Systems with Applications / 2014 \\
\hline Research method & Conceptual model \\
\hline SCM area & Reverse logistics \\
\hline KM processes & Creation; Storage; Transfer; Application \\
\hline 98. Author(s) & Lau, H.C.W., Ho, G.T.S., Zhao, Y., \& Chung, N.S.H. \\
\hline Article title & $\begin{array}{l}\text { Development of a process mining system for supporting knowledge discovery in a supply chain } \\
\text { network. }\end{array}$ \\
\hline Journal / Year & International Journal of Production Economics / 2009 \\
\hline Research method & Case study \\
\hline SCM area & Supply chain network \\
\hline KM processes & Creation \\
\hline 99. Author(s) & Le, H.Q., Arch-Int, S., Nguyen, H.X., \& Arch-Int, N. \\
\hline Article title & Association rule hiding in risk management for retail supply chain collaboration. \\
\hline Journal / Year & Computers in Industry / 2013 \\
\hline Research method & Case study \\
\hline SCM area & Risk management \\
\hline KM processes & Transfer \\
\hline 100. Author(s) & Lee, M.C., \& Chang, T. \\
\hline Article title & Linking knowledge management and innovation management in e-business \\
\hline Journal / Year & International Journal of Innovation and Learning / 2007 \\
\hline Research method & Conceptual model \\
\hline SCM area & Customer relationship management \\
\hline KM processes & Creation; Storage; Transfer \\
\hline 101. Author(s) & Li, X., \& Chandra, C. \\
\hline Article title & A knowledge integration framework for complex network management. \\
\hline Journal / Year & Industrial Management and Data Systems / 2007 \\
\hline Research method & Conceptual model \\
\hline SCM area & Risk management \\
\hline KM processes & Creation; Transfer \\
\hline 102. Author(s) & Li, X., \& Hu, J. \\
\hline Article title & Business Impact Analysis Based on Supply Chain's Knowledge Sharing ability \\
\hline Journal / Year & Procedia Environmental Sciences / 2012 \\
\hline Research method & Other \\
\hline SCM area & Supply chain strategy \\
\hline KM processes & Transfer \\
\hline
\end{tabular}




\begin{tabular}{|c|c|}
\hline 103. Author(s) & Li, Y., Kramer, M.R., Beulens, A.J.M., \& Van Der Vorst, J.G.A.J. \\
\hline Article title & A framework for early warning and proactive control systems in food supply chain networks \\
\hline Journal / Year & Computers in Industry / 2010 \\
\hline Research method & Case study \\
\hline SCM area & Decision-making \\
\hline KM processes & Creation; Storage; Transfer; Application \\
\hline 104. Author(s) & Li, Y., Tarafdar, M., \& Rao, S.S. \\
\hline Article title & Collaborative knowledge management practices: Theoretical development and empirical analysis \\
\hline Journal / Year & International Journal of Operations and Production Management / 2012 \\
\hline Research method & Survey \\
\hline SCM area & Supply chain integration \\
\hline KM processes & Creation; Storage; Transfer; Application \\
\hline 105. Author(s) & Li, Y., Liu, Y., \& Liu, H. \\
\hline Article title & $\begin{array}{l}\text { Co-opetition, distributor's entrepreneurial orientation and manufacturer's knowledge acquisition: } \\
\text { Evidence from China }\end{array}$ \\
\hline Journal / Year & Journal of Operations Management / 2011 \\
\hline Research method & Conceptual model \\
\hline SCM area & Intra and inter-firm relations \\
\hline KM processes & Creation \\
\hline 106. Author(s) & Liao, S.H., Chen, C.M., \& Wu, C.H. \\
\hline Article title & Mining customer knowledge for product line and brand extension in retailing \\
\hline Journal / Year & Expert Systems with Applications / 2008 \\
\hline Research method & Simulation \\
\hline SCM area & Product development \\
\hline KM processes & Creation; Storage \\
\hline 107. Author(s) & Liao, S.H., Chen, Y.N., \& Tseng, Y.Y. \\
\hline Article title & Mining demand chain knowledge of life insurance market for new product development \\
\hline Journal / Year & Expert Systems with Applications / 2009 \\
\hline Research method & Survey \\
\hline SCM area & Product development \\
\hline KM processes & Creation \\
\hline 108. Author(s) & Liew, C.B.A. \\
\hline Article title & Strategic integration of knowledge management and customer relationship management \\
\hline Journal / Year & Journal of Knowledge Management / 2008 \\
\hline Research method & Conceptual model \\
\hline SCM area & Customer relationship management \\
\hline KM processes & Creation; Transfer; Application \\
\hline 109. Author(s) & Lin, C.H., Hung, H.C., Wu, J.Y., \& Lin, B.S. \\
\hline Article title & A knowledge management architecture in collaborative supply chain \\
\hline Journal / Year & Journal of Computer Information Systems / 2002 \\
\hline Research method & Other \\
\hline SCM area & Supply chain collaboration \\
\hline KM processes & Creation; Storage; Transfer; Application \\
\hline
\end{tabular}




\begin{tabular}{|c|c|}
\hline 110. Author(s) & Lin, H.F. \\
\hline Article title & $\begin{array}{l}\text { The impact of socialization mechanisms and technological innovation capabilities on partnership } \\
\text { quality and supply chain integration. }\end{array}$ \\
\hline Journal / Year & Information Systems and e- Business Management / 2014 \\
\hline Research method & Survey \\
\hline SCM area & Supply chain integration \\
\hline KM processes & Transfer \\
\hline 111. Author(s) & Lintukangas, $\mathrm{K}$. \\
\hline Article title & Supplier relationship management capability in global supply management \\
\hline Journal / Year & International Journal of Procurement Management / 2011 \\
\hline Research method & Survey \\
\hline SCM area & Procurement / Supplier management \\
\hline KM processes & Creation \\
\hline 112. Author(s) & Liu, H., Ke, W., Wei, K.K., \& Hua, Z. \\
\hline Article title & $\begin{array}{l}\text { The impact of IT capabilities on firm performance: The mediating roles of absorptive capacity and } \\
\text { supply chain agility }\end{array}$ \\
\hline Journal / Year & Decision Support Systems / 2013 \\
\hline Research method & Survey \\
\hline SCM area & Other (SC agility) \\
\hline KM processes & Creation; Storage; Transfer; Application \\
\hline 113. Author(s) & Liu, H., Ke, W., Wei, K.K., \& Hua, Z. \\
\hline Article title & $\begin{array}{l}\text { Effects of supply chain integration and market orientation on firm performance: Evidence from } \\
\text { China }\end{array}$ \\
\hline Journal / Year & International Journal of Operations and Production Management / 2013 \\
\hline Research method & Survey \\
\hline SCM area & Supply chain integration \\
\hline KM processes & Transfer \\
\hline 114. Author(s) & Liu, S., Leat, M., Moizer, J., Megicks, P., \& Kasturiratne, D. \\
\hline Article title & $\begin{array}{l}\text { A decision-focused knowledge management framework to support collaborative decision making for } \\
\text { lean supply chain management }\end{array}$ \\
\hline Journal / Year & International Journal of Production Research / 2013 \\
\hline Research method & Case study \\
\hline SCM area & Lean supply chain \\
\hline KM processes & Creation; Storage; Transfer; Application \\
\hline 115. Author(s) & Liu, S., Moizer, J., Megicks, P., Kasturiratne, D., \& Jayawickrama, U. \\
\hline Article title & A knowledge chain management framework to support integrated decisions in global supply chains \\
\hline Journal / Year & Production Planning and Control / 2014 \\
\hline Research method & Interview \\
\hline SCM area & Global supply chain \\
\hline KM processes & Creation; Storage; Transfer; Application \\
\hline 116. Author(s) & Liu, Y., Huang, Y., Luo, Y., \& Zhao, Y. \\
\hline Article title & How does justice matter in achieving buyer-supplier relationship performance? \\
\hline Journal / Year & Journal of Operations Management / 2012 \\
\hline Research method & Survey \\
\hline
\end{tabular}




\begin{tabular}{|c|c|}
\hline SCM area & Intra and inter-firm relations \\
\hline KM processes & Transfer \\
\hline 117. Author(s) & Loke, S.P., Downe, A.G., Sambasivan, M., Kalid, K., \& Ooi, K.B. \\
\hline Article title & $\begin{array}{l}\text { A structural approach to integrating total quality management and knowledge management with } \\
\text { supply } \\
\text { chain learning }\end{array}$ \\
\hline Journal / Year & Journal of Business Economics and Management / 2012 \\
\hline Research method & Survey \\
\hline SCM area & Supply chain learning \\
\hline KM processes & Creation; Transfer; Application \\
\hline 118. Author(s) & London, K., \& Singh, V. \\
\hline Article title & Integrated construction supply chain design and delivery solutions \\
\hline Journal / Year & Architectural Engineering and Design Management / 2013 \\
\hline Research method & Case study \\
\hline SCM area & Decision-making \\
\hline KM processes & Creation \\
\hline 119. Author(s) & Lopez, G., \& Eldridge, S. \\
\hline Article title & A working prototype to promote the creation and control of knowledge in supply chains \\
\hline Journal / Year & International Journal of Networking and Virtual Organisations / 2010 \\
\hline Research method & Conceptual model \\
\hline SCM area & Supply chain learning \\
\hline KM processes & Creation; Storage; Transfer; Application \\
\hline 120. Author(s) & Lu, Q., Meng, F., \& Goh, M. \\
\hline Article title & Choice of supply chain governance: Self-managing or outsourcing? \\
\hline Journal / Year & International Journal of Production Economics / 2014 \\
\hline Research method & Mathematical model \\
\hline SCM area & Outsourcing \\
\hline KM processes & Transfer \\
\hline 121. Author(s) & Maçada, A.C.G., Costa, J.C., Oliveira, M., \& Curado, C. \\
\hline Article title & Information management and knowledge sharing in supply chains operating in Brazil \\
\hline Journal / Year & International Journal of Automotive Technology and Management / 2013 \\
\hline Research method & Case study \\
\hline SCM area & Intra and inter-firm relations \\
\hline KM processes & Transfer \\
\hline 122. Author(s) & Machikita, T., \& Ueki, Y. \\
\hline Article title & Knowledge transfer channels to Vietnam for process improvement \\
\hline Journal / Year & Management Decision / 2013 \\
\hline Research method & Survey \\
\hline SCM area & Intra and inter-firm relations \\
\hline KM processes & Transfer \\
\hline 123. Author(s) & Machikita, T., \& Ueki, Y. \\
\hline Article title & $\begin{array}{l}\text { Impacts of Incoming Knowledge on Product Innovation : Technology Transfer in Auto-Related } \\
\text { Industries in Developing Economies }\end{array}$ \\
\hline Journal / Year & Asian Journal of Technology Innovation / 2012 \\
\hline
\end{tabular}




\begin{tabular}{|c|c|}
\hline Research method & Survey \\
\hline SCM area & Product development \\
\hline KM processes & Transfer \\
\hline 124. Author(s) & Mak, K.T., \& Ramaprasad, A. \\
\hline Article title & Knowledge supply network \\
\hline Journal / Year & Journal of the Operational Research Society / 2003 \\
\hline Research method & Conceptual model \\
\hline SCM area & Supply chain network \\
\hline KM processes & Transfer \\
\hline 125. Author(s) & Malhotra, A., Gosain, S., \& E1 Sawy, O.A. \\
\hline Article title & $\begin{array}{l}\text { Absorptive capacity configurations in supply chains: Gearing for partner-enabled market knowledge } \\
\text { creation }\end{array}$ \\
\hline Journal / Year & MIS quarterly / 2005 \\
\hline Research method & Case study \\
\hline SCM area & Supply chain partnership \\
\hline KM processes & Creation \\
\hline 126. Author(s) & Malhotra, A., Gosain, S., \& E1 Sawy, O.A. \\
\hline Article title & Leveraging standard electronic business interfaces to enable adaptive supply chain partnerships \\
\hline Journal / Year & Information Systems Research / 2007 \\
\hline Research method & Interview \\
\hline SCM area & Supply chain partnership \\
\hline KM processes & Transfer \\
\hline 127. Author(s) & Maqsood, T., Walker, D., \& Finegan, A. \\
\hline Article title & Extending the knowledge advantage: Creating learning chains \\
\hline Journal / Year & Learning Organization / 2007 \\
\hline Research method & Case study \\
\hline SCM area & Supply chain learning \\
\hline KM processes & Creation; Transfer \\
\hline 128. Author(s) & Marra, M., Ho, W., \& Edwards, J.S. \\
\hline Article title & Supply chain knowledge management: A literature review \\
\hline Journal / Year & Expert systems with applications / 2012 \\
\hline Research method & Review \\
\hline 129. Author(s) & Mazzola, E., \& Perrone, G. \\
\hline Article title & A strategic needs perspective on operations outsourcing and other inter-firm relationships \\
\hline Journal / Year & International Journal of Production Economics / 2013 \\
\hline Research method & Conceptual model \\
\hline SCM area & Intra and inter-firm relations \\
\hline KM processes & Creation \\
\hline 130. Author(s) & McCoy, A.P., Thabet, W., \& Badinelli, R. \\
\hline Article title & $\begin{array}{l}\text { Understanding the role of developer/builders in the concurrent commercialization of product } \\
\text { innovation }\end{array}$ \\
\hline Journal / Year & European Journal of Innovation Management / 2009 \\
\hline Research method & Survey and Interview \\
\hline SCM area & Product development \\
\hline
\end{tabular}




\begin{tabular}{|c|c|}
\hline $\mathrm{KM}$ processes & Transfer \\
\hline 131. Author(s) & McLaughlin, S. \\
\hline Article title & Six tenets for developing an effective knowledge transfer strategy \\
\hline Journal / Year & VINE / 2010 \\
\hline Research method & Case study \\
\hline SCM area & Supply chain strategy \\
\hline KM processes & Transfer \\
\hline 132. Author(s) & McLaughlin, S., Paton, R.A., \& Macbeth, D.K. \\
\hline Article title & Barrier impact on organizational learning within complex organizations \\
\hline Journal / Year & Journal of knowledge management / 2008 \\
\hline Research method & Conceptual model \\
\hline SCM area & Supply chain learning \\
\hline KM processes & Creation; Transfer \\
\hline 133. Author(s) & Meixell, M.J., Shaw, N.C., \& Tuggle, F.D. \\
\hline Article title & A methodology for assessing the value of knowledge in a service parts supply chain \\
\hline Journal / Year & IEEE Transactions on Systems, Man and Cybernetics, Part B / 2008 \\
\hline Research method & Simulation \\
\hline SCM area & Forecasting / Demand planning \\
\hline KM processes & Creation; Storage; Transfer; Application \\
\hline 134. Author(s) & Mentzas, G., Apostolou, D., Kafentzis, K., \& Georgolios, P. \\
\hline Article title & Inter-organizational networks for knowledge sharing and trading \\
\hline Journal / Year & Information Technology and Management / 2006 \\
\hline Research method & Case study \\
\hline SCM area & Intra and inter-firm relations \\
\hline KM processes & Transfer \\
\hline 135. Author(s) & Modi, S.B., \& Mabert, V.A \\
\hline Article title & Supplier development: improving supplier performance through knowledge transfer. \\
\hline Journal / Year & Journal of operations management / 2007 \\
\hline Research method & Interview \\
\hline SCM area & Procurement / Supplier management \\
\hline KM processes & Transfer \\
\hline 136. Author(s) & More, D., \& Basu, P. \\
\hline Article title & $\begin{array}{l}\text { Challenges of supply chain finance: A detailed study and a hierarchical model based on the } \\
\text { experiences of an Indian firm }\end{array}$ \\
\hline Journal / Year & Business Process Management Journal / 2013 \\
\hline Research method & Survey \\
\hline SCM area & Supply chain relationship \\
\hline KM processes & Transfer \\
\hline 137. Author(s) & Muñoz, E., Capón-García, E., Laínez-Aguirre, J.M., Espuña, A., \& Puigjaner, L. \\
\hline Article title & Considering environmental assessment in an ontological framework for enterprise sustainability \\
\hline Journal / Year & Journal of Cleaner Production / 2013 \\
\hline Research method & Case study \\
\hline SCM area & Scheduling \\
\hline
\end{tabular}




\begin{tabular}{|c|c|}
\hline KM processes & Creation; Storage; Transfer; Application \\
\hline 138. Author(s) & Muñoz, E., Capón-García, E., Laínez, J.M., Espuña, A., \& Puigjaner, L. \\
\hline Article title & Using mathematical knowledge management to support integrated decision-making in the enterprise \\
\hline Journal / Year & Computers and Chemical Engineering / 2014 \\
\hline Research method & Mathematical model \\
\hline SCM area & Scheduling \\
\hline KM processes & Creation; Transfer \\
\hline 139. Author(s) & Nachiappan, S.P., Gunasekaran, A., \& Jawahar, N. \\
\hline Article title & Knowledge management system for operating parameters in two-echelon VMI supply chains \\
\hline Journal / Year & International Journal of Production Research / 2007 \\
\hline Research method & Case study \\
\hline SCM area & Inventory management \\
\hline KM processes & Creation; Storage; Transfer; Application \\
\hline 140. Author(s) & Nagarajan, S., Ganesh, K., \& Sundarakani, B. \\
\hline Article title & $\begin{array}{l}\text { Organisational readiness assessment framework and model for knowledge management - Application } \\
\text { for manufacturing supply chain }\end{array}$ \\
\hline Journal / Year & International Journal of Electronic Customer Relationship Management / 2009 \\
\hline Research method & Case study \\
\hline SCM area & Customer relationship management \\
\hline KM processes & Creation \\
\hline 141. Author(s) & Nagati, H., \& Rebolledo, C. \\
\hline Article title & Improving operational performance through knowledge exchange with customers \\
\hline Journal / Year & Production Planning and Control / 2013 \\
\hline Research method & Survey \\
\hline SCM area & Supply chain integration \\
\hline KM processes & Transfer \\
\hline 142. Author(s) & Nikabadi, M.S. \\
\hline Article title & $\begin{array}{l}\text { A framework for technology-based factors for knowledge management in supply chain of auto } \\
\text { industry }\end{array}$ \\
\hline Journal / Year & VINE / 2014 \\
\hline Research method & Survey \\
\hline SCM area & Supply chain integration \\
\hline $\mathrm{KM}$ processes & Creation; Storage; Transfer; Application \\
\hline 143. Author(s) & Nikabadi, M.S., \& Zamanloo, S.O.Z. \\
\hline Article title & $\begin{array}{l}\text { A multidimensional structure for describing the influence of supply chain strategies, business } \\
\text { strategies, and knowledge management strategies on knowledge sharing in supply chain }\end{array}$ \\
\hline Journal / Year & International Journal of Knowledge Management / 2012 \\
\hline Research method & Survey \\
\hline SCM area & Supply chain strategy \\
\hline KM processes & Transfer \\
\hline 144. Author(s) & Norbis, M., Meixell, M.J., \& Tuggle, F.D. \\
\hline Article title & Modelling security in the maritime supply chain using knowledge constructs \\
\hline Journal / Year & International Journal of Logistics Systems and Management / 2013 \\
\hline Research method & Other \\
\hline
\end{tabular}




\begin{tabular}{|c|c|}
\hline SCM area & Logistics management \\
\hline KM processes & Transfer \\
\hline 145. Author(s) & Oke, A., Prajogo, D.I., \& Jayaram, J. \\
\hline Article title & $\begin{array}{l}\text { Strengthening the innovation chain: The role of internal innovation climate and strategic relationships } \\
\text { with supply chain partners }\end{array}$ \\
\hline Journal / Year & Journal of Supply Chain Management / 2013 \\
\hline Research method & Survey \\
\hline SCM area & Supply chain partnership \\
\hline $\mathrm{KM}$ processes & Creation; Transfer \\
\hline 146. Author(s) & Ordoobadi, S.M., \& Wang, S. \\
\hline Article title & A multiple perspectives approach to supplier selection \\
\hline Journal / Year & Industrial Management and Data Systems / 2011 \\
\hline Research method & Case study \\
\hline SCM area & Procurement / Supplier management \\
\hline KM processes & Transfer \\
\hline 147. Author(s) & Patil, S.K., \& Kant, R. \\
\hline Article title & $\begin{array}{l}\text { A hybrid approach based on fuzzy DEMATEL and FMCDM to predict success of knowledge } \\
\text { management adoption in supply chain }\end{array}$ \\
\hline Journal / Year & Applied Soft Computing Journal / 2014 \\
\hline Research method & Case study \\
\hline SCM area & Decision-making \\
\hline KM processes & Creation; Storage; Transfer; Application \\
\hline 148. Author(s) & Patil, S.K., \& Kant, R. \\
\hline Article title & $\begin{array}{l}\text { A fuzzy AHP-TOPSIS framework for ranking the solutions of Knowledge Management adoption in } \\
\text { Supply Chain to overcome its barriers }\end{array}$ \\
\hline Journal / Year & Expert Systems with Applications / 2014 \\
\hline Research method & Case study \\
\hline SCM area & Decision-making \\
\hline KM processes & Creation; Storage; Transfer; Application \\
\hline 149. Author(s) & Patil, S.K., \& Kant, R. \\
\hline Article title & Ranking the barriers of knowledge management adoption in supply chain using fuzzy AHP method \\
\hline Journal / Year & International Journal of Business Innovation and Research / 2014 \\
\hline Research method & Other \\
\hline SCM area & Other (KM adoption) \\
\hline KM processes & Creation; Storage; Transfer; Application \\
\hline 150. Author(s) & Patil, S.K., \& Kant, R. \\
\hline Article title & $\begin{array}{l}\text { Knowledge management adoption in supply chain: Identifying critical success factors using fuzzy } \\
\text { DEMATEL approach }\end{array}$ \\
\hline Journal / Year & Journal of Modelling in Management / 2014 \\
\hline Research method & Other \\
\hline SCM area & Other (KM adoption) \\
\hline KM processes & Creation; Storage; Transfer; Application \\
\hline 151. Author(s) & Patil, S.K., \& Kant, R. \\
\hline Article title & $\begin{array}{l}\text { A fuzzy DEMATEL method to identify critical success factors of knowledge management adoption } \\
\text { in supply chain }\end{array}$ \\
\hline
\end{tabular}




\begin{tabular}{|c|c|}
\hline Journal / Year & Journal of Information and Knowledge Management / 2013 \\
\hline Research method & Case study \\
\hline SCM area & Decision-making \\
\hline KM processes & Creation; Storage; Transfer; Application \\
\hline 152. Author(s) & Paton, R.A., \& McLaughlin, S. \\
\hline Article title & Services innovation: Knowledge transfer and the supply chain. \\
\hline Journal / Year & European Management Journal / 2008 \\
\hline Research method & Other \\
\hline SCM area & Customer service management \\
\hline KM processes & Transfer \\
\hline 153. Author(s) & Paulraj, A., Lado, A.A., \& Chen, I.J. \\
\hline Article title & $\begin{array}{l}\text { Inter-organizational communication as a relational competency: antecedents and performance } \\
\text { outcomes in collaborative buyer-supplier relationships. }\end{array}$ \\
\hline Journal / Year & Journal of operations management / 2008 \\
\hline Research method & Survey \\
\hline SCM area & Intra and inter-firm relations \\
\hline KM processes & Transfer \\
\hline 154. Author(s) & Pedroso, M.C., \& Nakano, D. \\
\hline Article title & Knowledge and information flows in supply chains: A study on pharmaceutical companies. \\
\hline Journal / Year & International Journal of Production Economics / 2009 \\
\hline Research method & Interview \\
\hline SCM area & Forecasting / Demand planning \\
\hline KM processes & Transfer \\
\hline 155. Author(s) & Prakash, A., Chan, F.T.S., Liao, H., \& Deshmukh, S.G. \\
\hline Article title & Network optimization in supply chain: A KBGA approach \\
\hline Journal / Year & Decision Support Systems / 2012 \\
\hline Research method & Other \\
\hline SCM area & Supply chain network \\
\hline KM processes & Creation; Storage; Transfer; Application \\
\hline 156. Author(s) & Purwaningrum, F., \& Evers, H.D. \\
\hline Article title & $\begin{array}{l}\text { Knowledge Flow in the Academia-industry Collaboration or Supply Chain Linkage? Case Study of } \\
\text { the Automotive Industries in the Jababeka Cluster }\end{array}$ \\
\hline Journal / Year & Procedia-Social and Behavioral Sciences / 2012 \\
\hline Research method & Interview \\
\hline SCM area & Supply chain network \\
\hline KM processes & Transfer \\
\hline 157. Author(s) & Qi, K., \& Chen, W. \\
\hline Article title & Research on green supply chain knowledge sharing mechanism \\
\hline Journal / Year & Energy Education Science and Technology Part A: Energy Science and Research / 2014 \\
\hline Research method & Other \\
\hline SCM area & Green supply chain \\
\hline KM processes & Transfer \\
\hline 158. Author(s) & Raisinghani, M.S., \& Meade, L.L. \\
\hline Article title & Strategic decisions in supply-chain intelligence using knowledge management: An analytic-network- \\
\hline
\end{tabular}




\begin{tabular}{|c|c|}
\hline & process framework \\
\hline Journal / Year & Supply Chain Management / 2005 \\
\hline Research method & Case study \\
\hline SCM area & Decision-making \\
\hline KM processes & Creation; Storage; Transfer; Application \\
\hline 159. Author(s) & Ranganathan, C., Teo, T.S., \& Dhaliwal, J. \\
\hline Article title & Web-enabled supply chain management: Key antecedents and performance impacts \\
\hline Journal / Year & International Journal of Information Management / 2011 \\
\hline Research method & Survey and Interview \\
\hline SCM area & Other (web-enabled SCM) \\
\hline KM processes & Transfer \\
\hline 160. Author(s) & Rao, N.H. \\
\hline Article title & $\begin{array}{l}\text { A framework for implementing information and communication technologies in agricultural } \\
\text { development in India }\end{array}$ \\
\hline Journal / Year & Technological Forecasting and Social Change / 2007 \\
\hline Research method & Case study \\
\hline SCM area & Supply chain network \\
\hline $\mathrm{KM}$ processes & Transfer \\
\hline 161. Author(s) & Reychav, I. \\
\hline Article title & Knowledge sharing in a trade show: A learning spiral model \\
\hline Journal / Year & VINE / 2009 \\
\hline Research method & Survey \\
\hline SCM area & Distribution channels \\
\hline KM processes & Creation; Transfer \\
\hline 162. Author(s) & Rollins, M., Pekkarinen, S., \& Mehtälä, M. \\
\hline Article title & Inter-firm customer knowledge sharing in logistics services: An empirical study \\
\hline Journal / Year & International Journal of Physical Distribution and Logistics Management / 2011 \\
\hline Research method & Survey \\
\hline SCM area & Logistics management \\
\hline KM processes & Transfer \\
\hline 163. Author(s) & Samaddar, S., Nargundkar, S., \& Daley, M. \\
\hline Article title & $\begin{array}{l}\text { Inter-organizational information sharing: The role of supply network configuration and partner goal } \\
\text { congruence. }\end{array}$ \\
\hline Journal / Year & European Journal of Operational Research / 2006 \\
\hline Research method & Case study \\
\hline SCM area & Supply chain network \\
\hline KM processes & Transfer \\
\hline 164. Author(s) & Sambasivan, M., Loke, S.P., \& Abidin-Mohamed, Z. \\
\hline Article title & $\begin{array}{l}\text { Impact of knowledge management in supply chain management: A study in Malaysian manufacturing } \\
\text { companies }\end{array}$ \\
\hline Journal / Year & Knowledge and Process Management / 2009 \\
\hline Research method & Survey \\
\hline SCM area & Supply chain learning \\
\hline KM processes & Creation; Transfer; Application \\
\hline
\end{tabular}




\begin{tabular}{|c|c|}
\hline 165. Author(s) & Samuel, K.E., Goury, M.L., Gunasekaran, A., \& Spalanzani, A. \\
\hline Article title & Knowledge management in supply chain: An empirical study from France \\
\hline Journal / Year & Journal of Strategic Information Systems / 2011 \\
\hline Research method & Survey \\
\hline SCM area & Supply chain strategy \\
\hline KM processes & Creation; Transfer \\
\hline 166. Author(s) & Saxena, A., \& Wadhwa, S. \\
\hline Article title & Flexible configuration for seamless supply chains: Directions towards decision knowledge sharing \\
\hline Journal / Year & Robotics and Computer-Integrated Manufacturing / 2009 \\
\hline Research method & Simulation \\
\hline SCM area & Forecasting / Demand planning \\
\hline KM processes & Transfer \\
\hline 167. Author(s) & Scheuermann, A., \& Leukel, J. \\
\hline Article title & Supply chain management ontology from an ontology engineering perspective \\
\hline Journal / Year & Computers in Industry / 2014 \\
\hline Research method & Review \\
\hline 168. Author(s) & Schoenherr, T., Griffith, D.A., \& Chandra, A. \\
\hline Article title & Knowledge management in supply chains: The role of explicit and tacit knowledge \\
\hline Journal / Year & Journal of Business Logistics / 2014 \\
\hline Research method & Survey \\
\hline SCM area & Other (The role of explicit and tacit knowledge) \\
\hline KM processes & Creation; Application \\
\hline 169. Author(s) & Schrettle, S., Hinz, A., Scherrer-Rathje, M., \& Friedli, T. \\
\hline Article title & $\begin{array}{l}\text { Turning sustainability into action: Explaining firms' sustainability efforts and their impact on firm } \\
\text { performance }\end{array}$ \\
\hline Journal / Year & International Journal of Production Economics / 2014 \\
\hline Research method & Conceptual model \\
\hline SCM area & Sustainable supply chain \\
\hline KM processes & Creation; Transfer; Application \\
\hline 170. Author(s) & Sherwood, A.L., \& Covin, J.G. \\
\hline Article title & $\begin{array}{l}\text { Knowledge Acquisition in University-Industry Alliances: An Empirical Investigation from a Learning } \\
\text { Theory Perspective }\end{array}$ \\
\hline Journal / Year & Journal of Product Innovation Management / 2008 \\
\hline Research method & Survey \\
\hline SCM area & Supply chain partnership \\
\hline KM processes & Transfer; Application \\
\hline 171. Author(s) & Shih, S.C., Hsu, S.H.Y., Zhu, Z., \& Balasubramanian, S.K. \\
\hline Article title & Knowledge sharing-A key role in the downstream supply chain \\
\hline Journal / Year & Information and Management / 2012 \\
\hline Research method & Case study \\
\hline SCM area & Supply chain network \\
\hline $\mathrm{KM}$ processes & Transfer \\
\hline 172. Author(s) & Shunk, D.L., Carter, J.R., Hovis, J., \& Talwar, A. \\
\hline Article title & Electronics industry drivers of intermediation and disintermediation. \\
\hline
\end{tabular}




\begin{tabular}{|c|c|}
\hline Journal / Year & International Journal of Physical Distribution and Logistics Management / 2007 \\
\hline Research method & Survey and Interview \\
\hline SCM area & Supply chain integration \\
\hline KM processes & Transfer \\
\hline 173. Author(s) & Singh, P.J., \& Power, D. \\
\hline Article title & $\begin{array}{l}\text { Innovative knowledge sharing, supply chain integration and firm performance of Australian } \\
\text { manufacturing firms. }\end{array}$ \\
\hline Journal / Year & International Journal of Production Research / 2013 \\
\hline Research method & Survey \\
\hline SCM area & Supply chain integration \\
\hline KM processes & Transfer \\
\hline 174. Author(s) & Sivakumar, K., \& Roy, S. \\
\hline Article title & Knowledge redundancy in supply chains: A framework \\
\hline Journal / Year & Supply Chain Management / 2004 \\
\hline Research method & Conceptual model \\
\hline SCM area & Customer relationship management \\
\hline KM processes & Creation \\
\hline 175. Author(s) & Smith, A.D. \\
\hline Article title & $\begin{array}{l}\text { Customer relationship management: A look at incentive programmes and their usefulness in selected } \\
\text { service firms }\end{array}$ \\
\hline Journal / Year & International Journal of Business Innovation and Research / 2009 \\
\hline Research method & Case study \\
\hline SCM area & Customer relationship management \\
\hline KM processes & Transfer \\
\hline 176. Author(s) & Su, H.Y., Fang, S.C., \& Young, C.S. \\
\hline Article title & $\begin{array}{l}\text { Influences of relationship transparency from intellectual capital reporting on supply chain } \\
\text { partnerships with suppliers: A field experiment }\end{array}$ \\
\hline Journal / Year & Supply Chain Management / 2013 \\
\hline Research method & Survey and Interview \\
\hline SCM area & Supply chain partnership \\
\hline KM processes & Creation \\
\hline 177. Author(s) & Sudhindra, S., Ganesh, L.S., \& Arshinder, K. \\
\hline Article title & Classification of supply chain knowledge: A morphological approach \\
\hline Journal / Year & Journal of Knowledge Management / 2014 \\
\hline Research method & Conceptual model \\
\hline SCM area & Other (Classification of supply chain knowledge) \\
\hline KM processes & Creation \\
\hline 178. Author(s) & Tah, J.H.M., \& Carr, V. \\
\hline Article title & Towards a framework for project risk knowledge management in the construction supply chain \\
\hline Journal / Year & Advances in Engineering Software / 2001 \\
\hline Research method & Case study \\
\hline SCM area & Risk management \\
\hline KM processes & Storage \\
\hline 179. Author(s) & Tatham, P., \& Spens, K. \\
\hline
\end{tabular}




\begin{tabular}{|c|c|}
\hline Article title & Towards a humanitarian logistics knowledge management system \\
\hline Journal / Year & Disaster Prevention and Management / 2011 \\
\hline Research method & Conceptual model \\
\hline SCM area & Humanitarian logistics \\
\hline KM processes & Creation \\
\hline 180. Author(s) & Tatikonda, M.V., \& Stock, G.N. \\
\hline Article title & Product technology transfer in the upstream supply chain \\
\hline Journal / Year & Journal of Product Innovation Management / 2003 \\
\hline Research method & Conceptual model \\
\hline SCM area & Product development \\
\hline KM processes & Transfer \\
\hline 181. Author(s) & Tennant, S., \& Fernie, S. \\
\hline Article title & Organizational learning in construction supply chains \\
\hline Journal / Year & Engineering, Construction and Architectural Management / 2013 \\
\hline Research method & Interview \\
\hline SCM area & Supply chain learning \\
\hline KM processes & Transfer \\
\hline 182. Author(s) & Thomas, R.W., Fugate, B.S., \& Koukova, N.T. \\
\hline Article title & Coping with time pressure and knowledge sharing in buyer-supplier relationships. \\
\hline Journal / Year & Journal of Supply Chain Management / 2011 \\
\hline Research method & Case study \\
\hline SCM area & Supply chain relationship \\
\hline KM processes & Transfer \\
\hline 183. Author(s) & Thomas, S.P., Thomas, R.W., Manrodt, K.B., \& Rutner, S.M \\
\hline Article title & $\begin{array}{l}\text { An experimental test of negotiation strategy effects on knowledge sharing intentions in buyer-supplier } \\
\text { relationships. }\end{array}$ \\
\hline Journal / Year & Journal of Supply Chain Management / 2013 \\
\hline Research method & Conceptual model \\
\hline SCM area & Supply chain strategy \\
\hline KM processes & Transfer \\
\hline 184. Author(s) & Tseng, S.M. \\
\hline Article title & $\begin{array}{l}\text { The impact of knowledge management capabilities and supplier relationship management on } \\
\text { corporate performance }\end{array}$ \\
\hline Journal / Year & International Journal of Production Economics / 2014 \\
\hline Research method & Interview \\
\hline SCM area & Procurement / Supplier management \\
\hline KM processes & Creation; Application \\
\hline 185. Author(s) & Ulieru, M., Norrie, D., Kremer, R., \& Shen, W. \\
\hline Article title & A multi-resolution collaborative architecture for web-centric global manufacturing \\
\hline Journal / Year & Information Sciences / 2000 \\
\hline Research method & Simulation \\
\hline SCM area & Supply chain collaboration \\
\hline KM processes & Creation; Storage; Transfer; Application \\
\hline 186. Author(s) & Uusipaavalniemi, S., \& Juga, J. \\
\hline
\end{tabular}




\begin{tabular}{|c|c|}
\hline Article title & Information integration in maintenance services \\
\hline Journal / Year & International Journal of Productivity and Performance Management / 2008 \\
\hline Research method & Case study \\
\hline SCM area & Maintenance services \\
\hline KM processes & Transfer \\
\hline 187. Author(s) & Van Hoof, B. \\
\hline Article title & Organizational learning in cleaner production among Mexican supply networks \\
\hline Journal / Year & Journal of Cleaner Production / 2014 \\
\hline Research method & Case study \\
\hline SCM area & Sustainable supply chain \\
\hline KM processes & Creation \\
\hline 188. Author(s) & Verma, A., \& Tiwari, M.K. \\
\hline Article title & Role of corporate memory in the global supply chain environment. \\
\hline Journal / Year & International Journal of Production Research / 2009 \\
\hline Research method & Case study \\
\hline SCM area & Global supply chain \\
\hline KM processes & Creation \\
\hline 189. Author(s) & Viswanadham, N., \& Gaonkar, R. \\
\hline Article title & $\begin{array}{l}\text { A conceptual and analytical framework for management of integrated knowledge based logistics } \\
\text { providers. }\end{array}$ \\
\hline Journal / Year & International Journal of Logistics Systems and Management / 2009 \\
\hline Research method & Mathematical model \\
\hline SCM area & Logistics management \\
\hline KM processes & Transfer \\
\hline 190. Author(s) & Volpato, G., \& Stocchetti, A. \\
\hline Article title & Knowledge management in the automotive supply chain: Exploring suppliers' point of view \\
\hline Journal / Year & International Journal of Automotive Technology and Management / 2007 \\
\hline Research method & Conceptual model \\
\hline SCM area & Procurement / Supplier management \\
\hline KM processes & Creation; Transfer \\
\hline 191. Author(s) & Wadhwa, S., \& Saxena, A. \\
\hline Article title & Decision knowledge sharing: Flexible supply chains in KM context \\
\hline Journal / Year & Production Planning and Control / 2007 \\
\hline Research method & Simulation \\
\hline SCM area & Supply chain collaboration \\
\hline KM processes & Transfer \\
\hline 192. Author(s) & Wamba, S.F. \\
\hline Article title & $\begin{array}{l}\text { Achieving supply chain integration using RFID technology: the case of emerging intelligent B-to-B e- } \\
\text { commerce processes in a living laboratory }\end{array}$ \\
\hline Journal / Year & Business Process Management Journal / 2012 \\
\hline Research method & Case study \\
\hline SCM area & Supply chain integration \\
\hline KM processes & Transfer \\
\hline 193. Author(s) & Wang, C., Fergusson, C., Perry, D., \& Antony, J. \\
\hline
\end{tabular}




\begin{tabular}{|c|c|}
\hline Article title & A conceptual case-based model for knowledge sharing among supply chain members \\
\hline Journal / Year & Business Process Management Journal / 2008 \\
\hline Research method & Conceptual model \\
\hline SCM area & Supply chain learning \\
\hline KM processes & Creation; Storage; Transfer \\
\hline 194. Author(s) & Wang, X., Wong, T.N., \& Fan, Z.P. \\
\hline Article title & Ontology-based supply chain decision support for steel manufacturers in China \\
\hline Journal / Year & Expert Systems with Applications / 2013 \\
\hline Research method & Case study \\
\hline SCM area & Global supply chain \\
\hline KM processes & Creation; Storage; Transfer; Application \\
\hline 195. Author(s) & Warkentin, M., Sugumaran, V., \& Sainsbury, R. \\
\hline Article title & The role of intelligent agents and data mining in electronic partnership management \\
\hline Journal / Year & Expert Systems with Applications / 2012 \\
\hline Research method & Conceptual model \\
\hline SCM area & Supply chain partnership \\
\hline KM processes & Creation; Storage; Transfer; Application \\
\hline 196. Author(s) & Whitman, L.E., \& Panetto, H. \\
\hline Article title & The missing link: Culture and language barriers to interoperability. \\
\hline Journal / Year & Annual Reviews in Control / 2006 \\
\hline Research method & Conceptual model \\
\hline SCM area & Supply chain interoperability \\
\hline KM processes & Transfer \\
\hline 197. Author(s) & Williams, A.J. \\
\hline Article title & Transporting tacit supply knowledge in competitive environments: A storytelling perspective \\
\hline Journal / Year & International Journal of Procurement Management / 2014 \\
\hline Research method & Conceptual model \\
\hline SCM area & Supply chain strategy \\
\hline KM processes & Creation; Transfer \\
\hline 198. Author(s) & Wong, W.P., \& Wong, K.Y. \\
\hline Article title & $\begin{array}{l}\text { Supply chain management, knowledge management capability, and their linkages towards firm } \\
\text { performance }\end{array}$ \\
\hline Journal / Year & Business Process Management Journal / 2011 \\
\hline Research method & Survey \\
\hline SCM area & Supply chain partnership \\
\hline KM processes & Creation; Storage; Transfer; Application \\
\hline 199. Author(s) & Woolliscroft, P., Caganova, D., Cambal, M., Holecek, J., \& Pucikova, L. \\
\hline Article title & Implications for optimisation of the automotive supply chain through knowledge management. \\
\hline Journal / Year & Procedia CIRP / 2013 \\
\hline Research method & Case study \\
\hline SCM area & Just-in-time \\
\hline $\mathrm{KM}$ processes & Creation; Storage; Transfer; Application \\
\hline 200. Author(s) & Worasinchai, L., \& Daneshgar, F. \\
\hline
\end{tabular}




\begin{tabular}{|c|c|}
\hline Article title & Identifying knowledge transfer requirement in global organisational contexts. \\
\hline Journal / Year & International Journal of Innovation and Learning / 2012 \\
\hline Research method & Case study \\
\hline SCM area & Global supply chain \\
\hline KM processes & Transfer \\
\hline 201. Author(s) & Wrigley, N., Coe, N.M., \& Currah, A. \\
\hline Article title & Globalizing retail: conceptualizing the distribution-based transnational corporation (TNC) \\
\hline Journal / Year & Progress in Human Geography / 2005 \\
\hline Research method & Conceptual model \\
\hline SCM area & Retailing \\
\hline KM processes & Creation; Transfer \\
\hline 202. Author(s) & $\mathrm{Wu}, \mathrm{C}$ \\
\hline Article title & Knowledge creation in a supply chain. \\
\hline Journal / Year & Supply Chain Management: An International Journal / 2008 \\
\hline Research method & Case study \\
\hline SCM area & Customer relationship management \\
\hline KM processes & Creation \\
\hline 203. Author(s) & Wu, D.J. \\
\hline Article title & Software agents for knowledge management: Coordination in multi-agent supply chains and auctions \\
\hline Journal / Year & Expert Systems with Applications / 2001 \\
\hline Research method & Case study \\
\hline SCM area & Supply chain collaboration \\
\hline KM processes & Creation; Storage; Transfer; Application \\
\hline 204. Author(s) & Wynn, M., \& Olubanjo, O. \\
\hline Article title & Demand-supply chain management: Systems implications in an SME packaging business in the UK \\
\hline Journal / Year & International Journal of Manufacturing Research / 2012 \\
\hline Research method & Case study \\
\hline SCM area & Forecasting / Demand planning \\
\hline KM processes & Transfer \\
\hline 205. Author(s) & Xiuhong, W. \\
\hline Article title & Knowledge transfer research in the supply chain based on system dynamic model \\
\hline Journal / Year & ICIC Express Letters / 2014 \\
\hline Research method & Simulation \\
\hline SCM area & Supply chain integration \\
\hline KM processes & Transfer \\
\hline 206. Author(s) & Yam, A.Y.K., Chan, M.F.S., \& Chung, W.W.C. \\
\hline Article title & $\begin{array}{l}\text { Networked enterprise: A case study of implementing an information network system for global } \\
\text { product development }\end{array}$ \\
\hline Journal / Year & Benchmarking / 2007 \\
\hline Research method & Case study \\
\hline SCM area & Product development \\
\hline $\mathrm{KM}$ processes & Creation; Storage; Transfer; Application \\
\hline 207. Author(s) & Yang, J. \\
\hline
\end{tabular}




\begin{tabular}{|c|c|}
\hline Article title & Harnessing value in knowledge management for performance in buyer-supplier collaboration \\
\hline Journal / Year & International Journal of Production Research / 2013 \\
\hline Research method & Conceptual model \\
\hline SCM area & Supply chain relationship \\
\hline KM processes & Creation; Transfer \\
\hline 208. Author(s) & Yang, J. \\
\hline Article title & A structural model of supply chain performance in an emerging economy \\
\hline Journal / Year & International Journal of Production Research / 2012 \\
\hline Research method & Survey \\
\hline SCM area & Supply chain collaboration \\
\hline $\mathrm{KM}$ processes & Transfer \\
\hline 209. Author(s) & Yang, J., Rui, M., Rauniar, R., Ikem, F.M., \& Xie, H. \\
\hline Article title & $\begin{array}{l}\text { Unravelling the link between knowledge management and supply chain integration: An empirical } \\
\text { study }\end{array}$ \\
\hline Journal / Year & International Journal of Logistics Research and Applications / 2013 \\
\hline Research method & Case study \\
\hline SCM area & Supply chain integration \\
\hline KM processes & Creation; Transfer \\
\hline 210. Author(s) & Yang, J., Wong, C.W.Y., Lai, K.H., \& Ntoko, A.N. \\
\hline Article title & $\begin{array}{l}\text { The antecedents of dyadic quality performance and its effect on buyer-supplier relationship } \\
\text { improvement }\end{array}$ \\
\hline Journal / Year & International Journal of Production Economics / 2009 \\
\hline Research method & Survey \\
\hline SCM area & Supply chain relationship \\
\hline KM processes & Creation; Storage; Transfer; Application \\
\hline 211. Author(s) & Yazici, H.J. \\
\hline Article title & $\begin{array}{l}\text { Buyer perceptions on the buyer-supplier collaborative relationship and performance: A service } \\
\text { example }\end{array}$ \\
\hline Journal / Year & International Journal of Services and Operations Management / 2012 \\
\hline Research method & Survey \\
\hline SCM area & Supply chain relationship \\
\hline KM processes & Transfer \\
\hline 212. Author(s) & Ye, Y., Yang, D., Jiang, Z., \& Tong, L. \\
\hline Article title & Ontology-based semantic models for supply chain management. \\
\hline Journal / Year & The International Journal of Advanced Manufacturing Technology / 2008 \\
\hline Research method & Case study \\
\hline SCM area & Supply chain interoperability \\
\hline KM processes & Creation; Storage; Transfer \\
\hline 213. Author(s) & Yu, W., Jacobs, M.A., Salisbury, W.D., \& Enns, H. \\
\hline Article title & $\begin{array}{l}\text { The effects of supply chain integration on customer satisfaction and financial performance: An } \\
\text { organizational learning perspective }\end{array}$ \\
\hline Journal / Year & International Journal of Production Economics / 2013 \\
\hline Research method & Survey \\
\hline SCM area & Supply chain integration \\
\hline
\end{tabular}




\begin{tabular}{|c|c|}
\hline KM processes & Creation \\
\hline 214. Author(s) & Zacharia, Z.G., Nix, N.W., \& Lusch, R.F. \\
\hline Article title & Capabilities that enhance outcomes of an episodic supply chain collaboration \\
\hline Journal / Year & Journal of Operations Management / 2011 \\
\hline Research method & Survey \\
\hline SCM area & Supply chain collaboration \\
\hline KM processes & Creation; Storage; Transfer; Application \\
\hline 215. Author(s) & Zdravković, M., Panetto, H., Trajanović, M., \& Aubry, A. \\
\hline Article title & An approach for formalising the supply chain operations \\
\hline Journal / Year & Enterprise Information Systems / 2011 \\
\hline Research method & Conceptual model \\
\hline SCM area & Intra and inter-firm relations \\
\hline KM processes & Creation; Storage; Transfer \\
\hline 216. Author(s) & Zernand-Vilson, M., \& Elenurm, T. \\
\hline Article title & $\begin{array}{l}\text { Differences in implementing management and organization development directions between } \\
\text { domestic and foreign companies in Estonia. }\end{array}$ \\
\hline Journal / Year & Baltic Journal of Management / 2010 \\
\hline Research method & Survey \\
\hline SCM area & Global supply chain \\
\hline KM processes & Transfer \\
\hline 217. Author(s) & Zhang, M., \& Huo, B. \\
\hline Article title & The impact of dependence and trust on supply chain integration. \\
\hline Journal / Year & International Journal of Physical Distribution and Logistics Management / 2013 \\
\hline Research method & Survey \\
\hline SCM area & Supply chain integration \\
\hline KM processes & Transfer \\
\hline 218. Author(s) & Zhang, X., Chen, W., Tong, J., \& Liu, X. \\
\hline Article title & $\begin{array}{l}\text { Relational mechanisms, market contracts and cross-enterprise knowledge trading in the supply chain: } \\
\text { empirical research based on Chinese manufacturing enterprises }\end{array}$ \\
\hline Journal / Year & Chinese Management Studies / 2012 \\
\hline Research method & Survey and Interview \\
\hline SCM area & Intra and inter-firm relations \\
\hline KM processes & Transfer \\
\hline 219. Author(s) & Zhu, X., Mukhopadhyay, S.K., \& Kurata, H. \\
\hline Article title & A review of RFID technology and its managerial applications in different industries. \\
\hline Journal / Year & Journal of Engineering and Technology Management / 2012 \\
\hline Research method & Survey \\
\hline SCM area & Inventory management \\
\hline KM processes & Transfer \\
\hline
\end{tabular}

Note: SCM (supply chain management); KM (knowledge management) 
Journal of Industrial Engineering and Management, 2017 (www.jiem.org)

Article's contents are provided on an Attribution-Non Commercial 3.0 Creative commons license. Readers are allowed to copy, distribute and communicate article's contents, provided the author's and Journal of Industrial Engineering and Management's names are included. It must not be used for commercial purposes. To see the complete license contents, please visit http://creativecommons.org/licenses/by-nc/3.0/. 